2. Jo: (Receiving Organization)

Distribution

5. Proj./Prog./Dept./Div.:

Waste Management

8. Originator Remarks:

This document is being processed for release.

3. From: (originating organization)

Retrieval Engineering 73530

6. Cog. Engr.:

G. T. Maclean

11. Receiver Remarks:

DATA TRANSMITTED

15.

(A)

No.

(B) Document/Drawing No

No.

No.

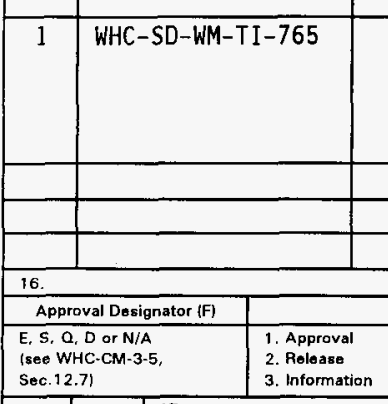

\begin{tabular}{|l|l|l|l|}
\hline (G) & (H) & 17. &
\end{tabular}

0 Pretreatment Applied

Engineering,

Corrosion Assessment

for Tank Materials:

1995 Final Report
4. Related EDT No.:

$N / A$

7. Purchase Order Mo.:

N/A

9. Equip./Component No.:

$N / A$

10. System/Bldg./Facility:

$N / A$

12. Major Assm. Dwg. No.:

N/A

13. Permit/Permit Application No.: $N / A$

14. Required Response Date:

$N / A$

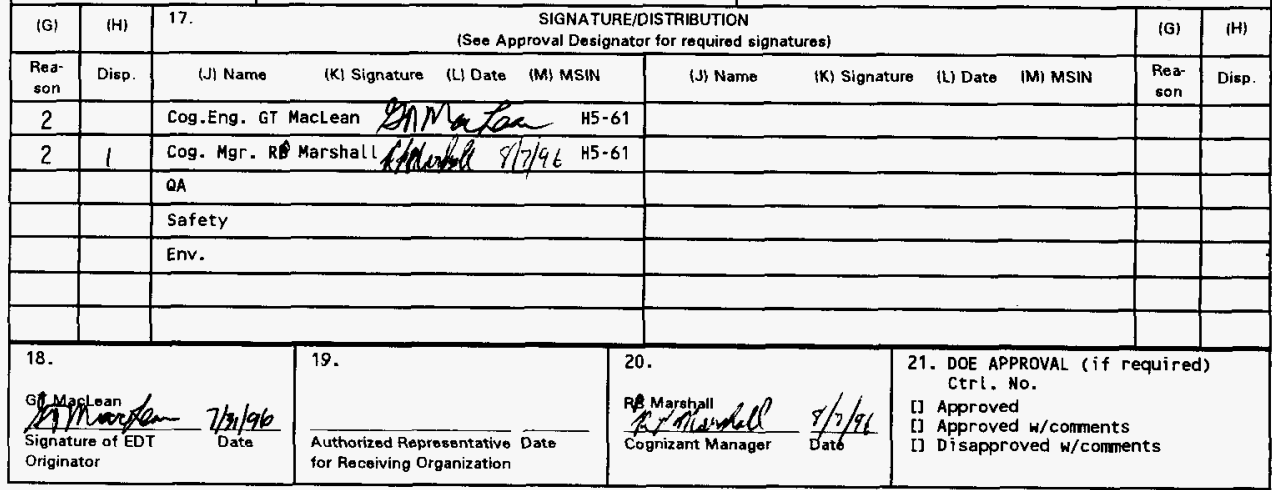

BD-7400-172-2(04/94) GEF097 


\section{Pretreatment Applied Engineering, Corrosion Assessment for Tank Materials: 1995 Final Report}

Graham T. MacLean

Westinghouse Hanford Company, Richland, WA 99352

U.S. Department of Energy Contract DE-ACO5-87RL10930

$\begin{array}{llll}\text { EDT/ECN: } & 605663 & \text { UC: } & 2000 \\ \text { Org Code: } & 73530 & \text { Charge Code: } & 02094 \\ \text { B\&R Code: } & \text { EW3130010 } & \text { Total Pages: } & 161\end{array}$

Key Words: radioactive waste storage tanks, carbon stee1, SCC, pitting, general attack, Hanford waste tanks

Abstract: For sludge washing to be conducted in existing Hanford carbon steel tanks, there must be an assurance that the tanks will be safe from failure by pitting, stress-corrosion cracking or other failure processes when the corrosion inhibitors present in the waste are diluted during the sludge washing operation. Testing has been conducted previously to define safe operating regimes in concentrated waste environments and moderately dilute waste environments. Due to ident ification of unsafe operating regimes for moderately dilute waste environments, testing was conducted in more dilute environments to adequately capture the range of possible chemistries during sludge washing operations. Additionally, a small scoping study was performed to identify the corrosion effects of high levels of chloride in the waste environments.

six month exposure coupon tests, slow strain rate tests, and potentiodynamic scans have been completed on a statistically designed test matrix of twenty-four tests. Stress-corrosion cracking was not found for the specimens in the static tests or the slow strain rate tests. Pitting and crevice corrosion was found for many of the solutions, but primarily in the vapor phase. Waterline attack at the vapor space/solution interface was common for the range of solutions tested. Gross general attack was found for the specimens exposed to the vapor space of the high chloride solutions.

TRADEMARK DISCLAIMER. Reference herein to any specific comercial product, process, or service by trade name, trademark, manufacturer, or otherwise, does not necessarily constitute or imply its endorsement, recommendation, or favoring by the United States Government or any agency thereof or its contractors or subcontractors.

Printed in the United States of America. To obtain copies of this document, contact: WHC/BCS Document Control Services, P.O. Box 1970, Mailstop H6-08, Richland WA 99352, Phone (509) 372-2420; Fax (509) 376-4989.
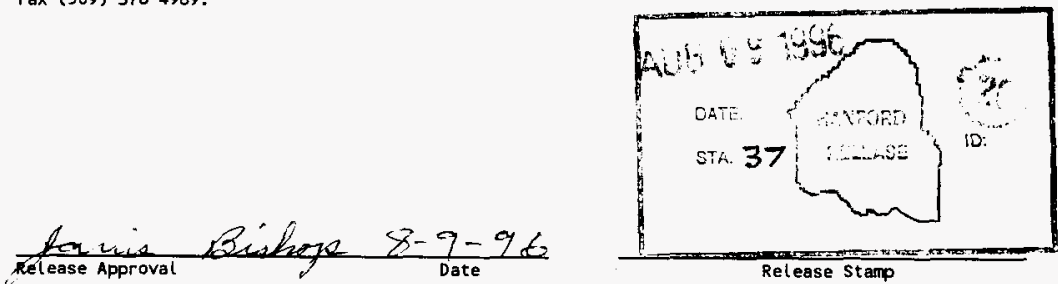
WHC-SD-WM-TI-765, Rev 0

\section{PRETREATMENT APPLIED ENGINEERING, CORROSION ASSESSMENT \\ FOR TANK MATERIALS: \\ 1995 FINAL REPORT}

July 1996

G. T. MacLean

Prepared by:

Pacific Northwest National Laboratory

Richland, Washington

for:

Westinghouse Hanford Company

Richl and, Washington 


\section{SUMMARY}

For sludge washing to be conducted in existing Hanford carbon steel tanks, there must be an assurance that the tanks will be safe from failure by pitting, stress-corrosion cracking or other failure processes when the corrosion inhibitors present in the waste are diluted during the sludge washing operation. Testing has been conducted previously to define safe operating regimes in concentrated waste environments and moderately dilute waste environments. Due to identification of unsafe operating regimes for moderately dilute waste environments, testing was conducted in more dilute environments to adequately capture the range of possible chemistries during sludge washing operations. Additionally, a small scoping study was performed to identify the corrosion effects of high levels of chloride in the waste environments.

Six month exposure coupon tests, slow strain rate tests, and potentiodyuamic scans have been completed on a statistically designed test matrix of twenty-four tests. Stress-corrosion cracking was not found for the specimens in the static tests or the slow strain rate tests. Pitting and crevice corrosion was found for many of the solutions, but primarily in the vapor phase. Waterline attack at the vapor space/solution interface was common for the range of solutions tested. Gross general attack was found for the specimens exposed to the vapor space of the high chloride solutions. 


\section{ACKNOWLEDGMENTS}

The authors, A. L. Lund and M. J. Danielson, thank Graham MacLean of Westinghouse Hanford Company for technical assistance with this project. Additionally, thanks are extended to L. K. Holton, Manager of the Pacific Northwest Laboratory Tank Waste Remediation System Group for his programmatic guidance. And finally, special thanks are extended to Dick Watson for his work with the U-bend and coupon tests, to Steve Faber and Bill Gerry for their work with the slow-strain-rate tests, and to Don Daly for his statistical assistance in developing the test matrix. 


\section{CONTENTS}

1.0 INTRODUCTION . . . . . . . . . . . . . . . . . . . . . . . . 1

2.0 TEST APPROACH . . . . . . . . . . . . . . . . . . 2

3.0 EXPERIMENTAL DESIGN AND SETUP . . . . . . . . . . . . . . . . . 8

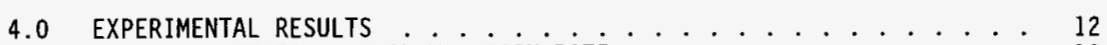

4.1 SCC TESTING BY SLOW STRAIN RATE . . . . . . . . . . . . . . . 12

4.2 POTENTIODYNAMIC PITTING TESTING . . . . . . . . . . . . . 14

4.3 STATIC TESTS . . . . . . . . . . . . . . . 17

5.0 DISCUSSION . . . . . . . . . . . . . . . . . . . . . . . 29

5.1 EFFECTS OF CHLORIDES ................. . . 29

5.2 PITTING AND CREVICE CORROSION ............... 30

5.3 UNIFORM CORROSION . . . . . . . . . . . . . . . . . . 30

5.4 STRESS CORROSION CRACKING . . . . . . . . . . . . . . 30

6.0 RECOMMENDATIONS FOR FUTURE WORK . . . . . . . . . . . . . . . 32

7.0 CONCLUSIONS . . . . . . . . . . . . . . . . . . . 33

8.0 REFERENCES ......................... . . . . 34

APPENDIX A: SEM PHOTOGRAPHS OF SLOW STRAIN RATE SPECIMEN FRACTURE

SURFACES ...................... . . A-i

APPENDIX B: POTENTIODYNAMIC SCANS . . . . . . . . . . . . . . . . . . B-

APPENDIX $C$ : PHOTOGRAPHS OF REPRESENTATIVE SPECIMENS PRIOR TO CLEANING . $c-i$ APPENDIX D: WEIGHT LOSS DATA . . . . . . . . . . . . . . . . . . D-

APPENDIX E: OPTICAL PHOTOGRAPHS OF CLEANED SPECIMENS . . . . . . . . . . . E-i

APPENDIX F: OBSERVATIONS ON CLEANED SPECIMENS . . . . . . . . . . . . . F-i 
TABLES

Table 1. A-515 Chemical Properties. . . . . . . . . . . . . 3

Table 2. A-515 Physical Properties. ........... 3

Table 3. Test Solutions, Constrained Test Design for Studying the Effects of Nitrate, Nitrite, and Hydroxide in Dilute Waste Environments. . . . . . . . . . . . 4

Table 4. Test Solutions, One-Half Fractional Factorial Test Design for Studying the Effect of Chloride in Dilute Waste Environments. . 5

Table 5. Slow Strain Rate Data. . . . . . . . . . . ... 13

Table 6. Pitting Experimental Data. . . . . . . . . . . . 16

Table 7. Visual Observations From Static Tests and Slow Strain Rate Tests. . . . . . . . . . . 20

Table 8. Comparison of Density of Attack With Depth of Attack. . . . 2 21

\section{FIGURES}

Figure 1. 1995 Test Matrix for S7udge Washing Corrosion Assessment. . . 6

Figure 2. Integrated Test Matrix: 1994 and 1995 Sludge Washing Corrosion Assessment. . . . . . . . . . . . 7

Figure 3. Schematic of the Slow-strain-rate Test Apparatus. . . . . . 99

Figure 4. Schematic Showing Test Set-up for the Potentiodynamic Polarization Tests. ............... 10

Figure 5. Configuration of the U-bend Specimen Used for Static Corrosion Testing. .............. 11

Figure 6. Sludge-Washing Compositions That Led to Secondary Cracking in 1995 Test Matrix. . . . . . . . . . . . 22

Figure 7. Maximum Pit Depth for Specimens Immersed in Solutions. . . 23

Figure 8. Maximum Pit Depth for Specimens in Vapor Phase. . . . . . 24

Figure 9. Maximum Depth of Crevice Attack in Immersed Specimens. . . . 25

Figure 10. Maximum Depth of Crevice Attack in Vapor Phase Specimens. . . 26

Figure 11. Maximum Depth of Waterline Attack in Vapor Phase Specimens. . 27

Figure 12. Sludge-Washing Compositions That Led to Pitting, Crevice, or Waterline Attack $\geq 0.05 \mathrm{~mm}$ in the 1995 Test Matrix.... 28 
WHC-SD-WM-TI-765, Rev 0

\section{ACRONYMS AND ABBREVIATIONS}

ASTM American Society for Testing Materials

$E_{\text {coor open circuit potential }}$

$E_{p i t}^{\text {pitting potential }}$

$E_{\text {prot }}$ protection potential

$\mathrm{HCW}$ high-level waste

PNNL Pacific Northwest National Laboratory

WHC Westinghouse Hanford Company

SCC stress corrosion cracking

SSR slow strain rate 


\section{PRETREATMENT APPLIED ENGINEERING, CORROSION ASSESSMENT \\ FOR TANK MATERIALS: \\ 1995 FINAL REPORT}

\subsection{INTRODUCTION}

Pretreatment of the radioactive tank waste in storage at the Hanford site will be used to minimize the volume of the high-level waste (HLW), and thereby reduce the attendant costs of disposal. One step in the pretreatment of HLW is sludge washing, which may be performed in the existing double-shell carbon steel tanks. Sludge washing will include pumping the supernatant liquid out of the tank, adding water to the sludge volume, mixing the contents, settling the contents, and then pumping off the aqueous phase. Multiple washing steps are planned in order to remove the soluble constituents.

Currently, the concentrated wastes are maintained to compositional specifications (Ondrejcin 1978, Kirch 1984) that prevent stress corrosion cracking (SCC). There is a major concern that the washing operations using raw water (without inhibitors) could jeopardize the tank integrity by SCC and pitting attack, because the corrosion-inhibiting effect of hydroxide and nitrite ions would be lost through excessive dilution. Ideally, the wash water should contain sufficient levels of corrosion inhibitor to minimize pitting, cracking, or uniform attack and at the same time add very little additional burden to the amount of dissolved solids that must be processed.

Corrosion testing began at the Pacific Northwest National Laboratory (PNNL) in FY 94 to provide experimental data to guide in adding the minimum amount of inhibitor chemicals to the wash water, consistent with avoiding tank failures by SCC, pitting, and uniform attack (Danielson and Bunnell 1994). Stress-corrosion cracking and potentially serious pitting in the vapor phase were observed in specimens exposed to two of the sixteen statistically designed solution environments investigated in these FY 94 studies: Based on these test results, testing in FY 95 focused on the following: (1) better definition of prototypical waste solution environments, (2) better definition of the compositional regime that separates the corrosive chemical environments from the benign chemical environments, and (3) examination of the effects of chloride ion which was not evaluated in FY 94 . The FY 95 solution compositions were selected by coordination with Westinghouse Hanford Company (WHC) process engineers and a PNNL statistician. Corrosion test results are reported for the FY 95 electrochemical tests, slow strain rate tests, and coupon tests. 


\subsection{TEST APPROACH}

Three types of tests at $93 \pm 3^{\circ} \mathrm{C}\left(200^{\circ} \mathrm{F}\right)$ were carried out: slow strain rate tests to evaluate SCC propensity: static tests with totaliy-immersed and half-immersed U-bends and plain coupon specimens to evaluate the SCC, pitting, crevice, and uniform corrosion attack behavior; and electrochemical tests. Crevice corrosion was evaluated by using serrated polytetrafluroethylene washers under the bolts loading the U-bends. Test specimens were A-515 steel that were given a twenty-four hour heat treatment at $593^{\circ} \mathrm{C}\left(1100^{\circ} \mathrm{F}\right)$. The tanks were originally given a one hour heat treatment, but the longer heat treatment given to the specimens increases their propensity for SCC (Sarafian 1975), resulting in a more conservative test condition. The chemical and physical properties (before the heat treatment) of the A-515 steel are shown in Tables 1 and 2 for the FY 94 and FY 95 materials. The supplier was unable to duplicate the same heat of $\mathbf{A 5 1 5}$ for the FY 95 testing.

A-515 steels were studied because a good possibility exists that the earliest washed tanks (constructed of A-515) will be used as the long-term sludge washing containers for the other tanks. Consequently, the A-515 tanks will have the longest exposure to the washed environments and the greatest chance for some slow failure process to occur. A-537 carbon steel was used in later-built tanks. It is hypothesized that the corrosion behavior of A-515 can be used as an accurate predictor for that of A-537.

Nitrate, nitrite, and free hydroxide are the three independent variables that have the most effect on the corrosion response. A statistical experimental design was used to define the test solution compositions because of the expected complexity of the interaction among these variables and the wide variety in the tank solution compositions. The range of each variable is shown below:

$$
\begin{array}{lc}
\text { Nitrate: } & 0.025 \text { to } 1.00 \mathrm{M} \\
\text { Nitrite: } & 0.01 \text { to } 0.393 \mathrm{M} \\
\text { Hydroxide: } & 0.01 \text { to } 0.389 \mathrm{M} \\
\text { Chloride: } & <0.001 \text { to } 0.500 \mathrm{M}
\end{array}
$$

Additional minor waste components were maintained at a low level in each solution to better simulate actual waste solutions:
Sodium carbonate:
Sodium sulfate:
$0.01 \mathrm{M}$
Sodium phosphate:
$0.01 \mathrm{M}$
$0.001 \mathrm{M}$ 
Table 1. A-515 Chemical Properties.

\begin{tabular}{||c|c|c|c|c|c|c|c|c|c||}
\hline $\mathrm{C}$ & $\mathrm{Cr}$ & $\mathrm{Cu}$ & $\mathrm{Mn}$ & $\mathrm{Mo}$ & $\mathrm{Ni}$ & $\mathrm{P}$ & $\mathrm{S}$ & $\mathrm{Si}$ & Other \\
\hline \hline 0.21 & 0.20 & 0.25 & 0.54 & 0.07 & 0.24 & $\begin{array}{c}0.02 \\
3\end{array}$ & $\begin{array}{c}0.01 \\
3\end{array}$ & 0.22 & $\begin{array}{c}\text { V } \\
0.003 \\
\mathrm{Cb} 0.001\end{array}$ \\
\hline \hline
\end{tabular}

Table 2. A-515 Physical Properties.

\begin{tabular}{|c|c|c|c|c|c|c|}
\hline A110y & Heat & $\begin{array}{c}\text { Tensile, } \\
\mathrm{MPa}\end{array}$ & $\begin{array}{c}\text { Yield, } \\
\mathrm{MPa}\end{array}$ & $\underset{\%}{\text { Elong, }}$ & UNS & Supplier \\
\hline \multicolumn{7}{|c|}{ FY 94 Specimen Material: } \\
\hline$\underset{60}{\mathrm{~A} 515, \mathrm{Gr}}$ & J567 & 551 & 405 & 23 & K02401 & $\begin{array}{c}\text { Metal } \\
\text { Samples }\end{array}$ \\
\hline \multicolumn{7}{|c|}{ FY 95 Specimen Material: } \\
\hline $\begin{array}{l}A 515, \mathrm{Gr} \\
60\end{array}$ & K604 & 525 & 341 & 23 & K02401 & $\begin{array}{l}\text { Metal } \\
\text { Samples }\end{array}$ \\
\hline
\end{tabular}

The composition of the 24 statistically designed test solutions is shown in Tables 3 and 4 (solutions 12 and 20, as well as 7 and 19, are identical for the statistical purpose of measuring the standard error). Chloride was not added for the 'low' chloride solutions represented in Table 3 , because chloride is an impurity in sodium hydroxide; so some chloride will be present in every solution. The chloride concentrations for the low chloride solutions varied from $<5 \mathrm{mg} / \mathrm{L}$ to $30 \mathrm{mg} / \mathrm{L}$ for the range of sodium hydroxide in the test solutions. The high chloride solutions, shown in Table 4 , containing $0.5 \underline{M}$ chloride, were used to perform a scoping test on the effects of chloride on the corrosion susceptibility of the A-515 steel. The solution compositions are more clearly shown in the three-dimensional plots of Figures 1 and 2 . Figure 1 shows only the 1995 test matrix while figure 2 shows the integrated test matrix containing the test concentrations from both the 1994 and 1995 test matrices. 
Table 3. Test Solutions, Constrained Test Design for Studying the Effects of Nitrate, Nitrite, and Hydroxide in Dilute Waste Environments.

\begin{tabular}{|c|c|c|c|}
\hline Solution & Nitrite, $\underline{M}$ & Nitrate, $\underline{M}$ & Hydroxide, $\underline{M}$ \\
\hline 1 & 0.03 & 0.10 & 0.03 \\
\hline 2 & 0.01 & 0.10 & 0.03 \\
\hline 3 & 0.10 & 1.00 & 1.00 \\
\hline 4 & 0.30 & 1.00 & 0.10 \\
\hline 5 & 0.03 & 0.30 & 0.03 \\
\hline 6 & 0.03 & 0.10 & 0.01 \\
\hline 7 & 0.01 & 0.10 & 0.10 \\
\hline 8 & 0.30 & 1.00 & 0.30 \\
\hline 9 & 0.10 & 0.30 & 0.03 \\
\hline 10 & 0.01 & 0.10 & 0.01 \\
\hline 11 & 0.10 & 0.10 & 0.01 \\
\hline 12 & 0.10 & 1.00 & 0.10 \\
\hline 13 & 0.30 & 0.30 & 0.03 \\
\hline 14 & 0.10 & 1.00 & 0.30 \\
\hline 15 & 0.03 & 0.30 & 0.30 \\
\hline 16 & 0.03 & 0.30 & 0.10 \\
\hline 17 & 0.10 & 0.30 & 0.30 \\
\hline 18 & 0.10 & 0.30 & 0.10 \\
\hline 19 & 0.01 & 0.10 & 0.10 \\
\hline 20 & 0.10 & 1.00 & 0.10 \\
\hline
\end{tabular}


WHC-SD-WM-TI-765, Rev 0

Table 4. Test Solutions, One-Half Fractional Factorial Test Design for Studying the Effect of Chloride in Dilute Waste Environments.

\begin{tabular}{|c|c|c|c|c|}
\hline Solution & Nitrite, $\underline{M}$ & Nitrate, $\underline{M}$ & Hydroxide, $\underline{\mathrm{M}}$ & $\begin{array}{c}\text { Chloride, } \\
M\end{array}$ \\
\hline 21 & 0.025 & 0.025 & 0.389 & 0.500 \\
\hline 22 & 0.025 & 0.393 & 0.026 & 0.500 \\
\hline 23 & 0.393 & 0.025 & 0.026 & 0.500 \\
\hline 24 & 0.393 & 0.393 & 0.389 & 0.500 \\
\hline
\end{tabular}




\section{Test Matrix \\ Corrosion Assessment for Sludge Washing}

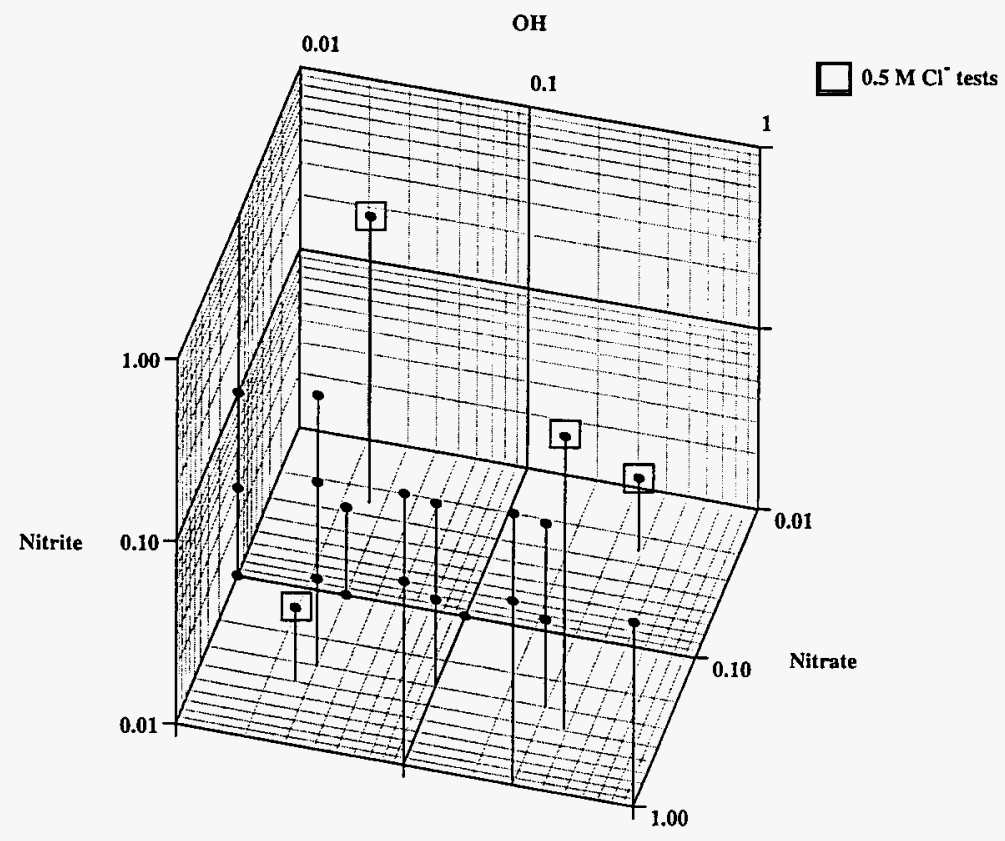

Figure 1. 1995 Test Matrix for Sludge Washing Corrosion Assessment. 
WHC-SD-HM-TI-765, Rev 0

Integrated Test Matrix: 1994 and 1995

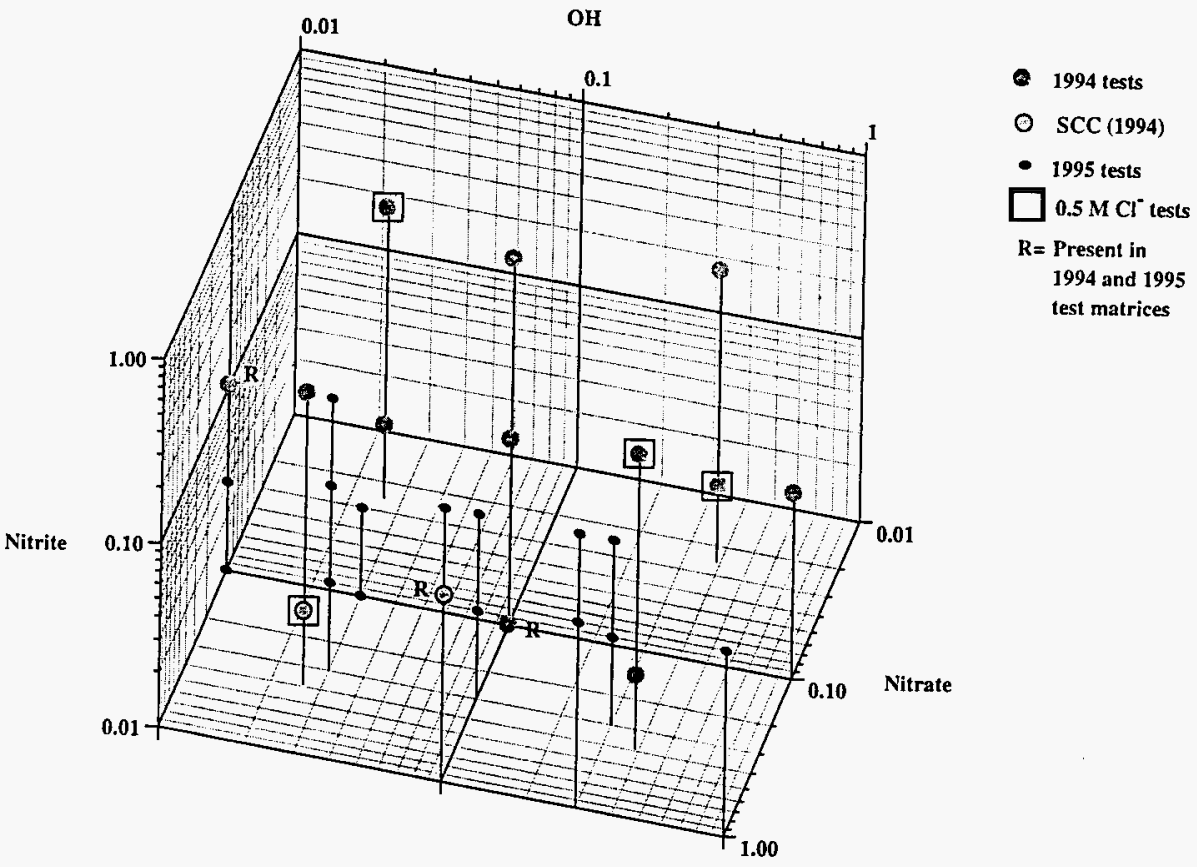

Figure 2. Integrated Test Matrix: 1994 and 1995 Sludge Washing Corrosion Asses sment. 


\subsection{EXPERIMENTAL DESIGN AND SETUP}

SCC propensity was evaluated from slow strain rate tests in each of the 24 solutions by time to failure, percent elongation, reduction in tensile strength, reduction of area, and fractographic indications of brittle fracture. A slow strain rate apparatus with a nickel-base alloy vessel was used as schematically shown in Figure 3. Care was taken to electrically isolate the A-515 steel specimens from the test machine to eliminate galvanic effects with the nickel-base alloy. The dogbone-shaped specimens had a gage width and thickness of $0.635 \mathrm{~cm}(0.25$ inches) with a gage length of $2.54 \mathrm{~cm}$ (1.0 inches). The slow strain rate tests were carried out at a strain rate of $1.3 \mathrm{E}-6 / \mathrm{sec}$, the same rate as Ondrejcin (1984) used in his Savannah River Laboratory study on the cracking of carbon steels in concentrated simulated waste solutions. The only exception to this strain rate was the one test performed in solution 12 , at a strain rate of $3.25 \mathrm{E}-7 / \mathrm{sec}$. This test was performed to investigate the cause of the discrepancy between results from the FY 94 testing and current FY 95 test results. A test would typically last three days. Air was continually sparged through the solution, which was maintained at $93 \pm 3^{\circ} \mathrm{C}$. No welded specimens were evaluated.

Pitting propensity was evaluated in each test solution using the potentiodynamic method to determine the pitting and protection potential. These tests involve polarizing the specimen with a potentiostat according to American Society for Testing Materials (ASTM) standards G-3 and G-5 at a scan rate of $0.2 \mathrm{mV} / \mathrm{s}$. The test set-up is shown schematically in Figure 4 . Potentials were measured relative to a $\mathrm{Ag}$, $\mathrm{AgCl}$ reference electrode $(4.0 \mathrm{~m} \mathrm{KCl}$ electrolyte) at the $93 \pm 3^{\circ} \mathrm{C}\left(200^{\circ} \mathrm{F}\right)$ solution temperature. The electrochemical tests reveal pitting propensity by determining the existence and value of an electrochemical pitting potential (potential at which pitting starts) and protection potential (potential at which pits stop growing).

Additionally, there were 24 static solution tests containing A-515 coupons. Tests were performed in two-liter polypropylene bottles containing three totally immersed $U$-bends and three totally immersed flat, uniform corrosion specimens. Three U-bends and three flat specimens were also mounted at the solution/vapor interface in each bottle. Each U-bend (shown schematically in Figure 5) at the solution/vapor interface was positioned with the maximum stressed region at the interface. Polytetrafluoroethylene crevice washers were used under the stressing bolts for all the U-bends to serve as a crevice corrosion test. The test bottles were maintained at $93 \pm 3^{\circ} \mathrm{C}$ in three air ovens (eight bottles/oven). Each bottle was sparged with carbon dioxidefree air at $1.3 \mathrm{~L}$ /day to maintain the oxygen concentration (the carbon dioxide was scavenged with Ascarite). An air condenser was fitted to each of the 24 containers. Deionized water was added to each container as needed to compensate for evaporation losses.

The testing program was conducted according to the Tank Waste Remediation System Test P1an, TWRS-95-6.2, Revision 1 . 
Slow Strain Rate Test System

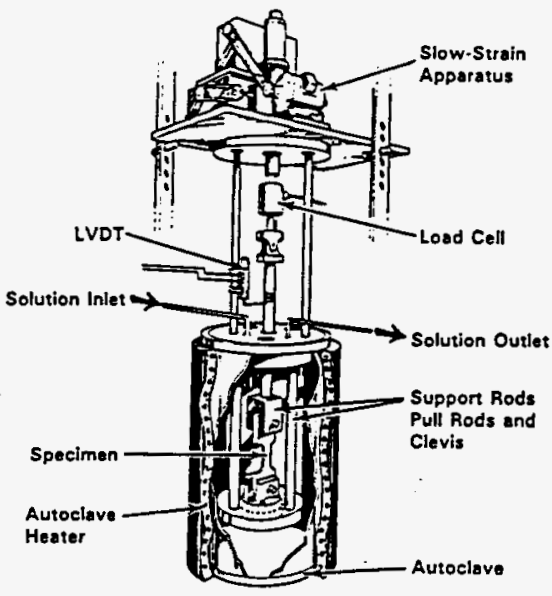

Figure 3. Schematic of the Slow-strain-rate Test Apparatus. 


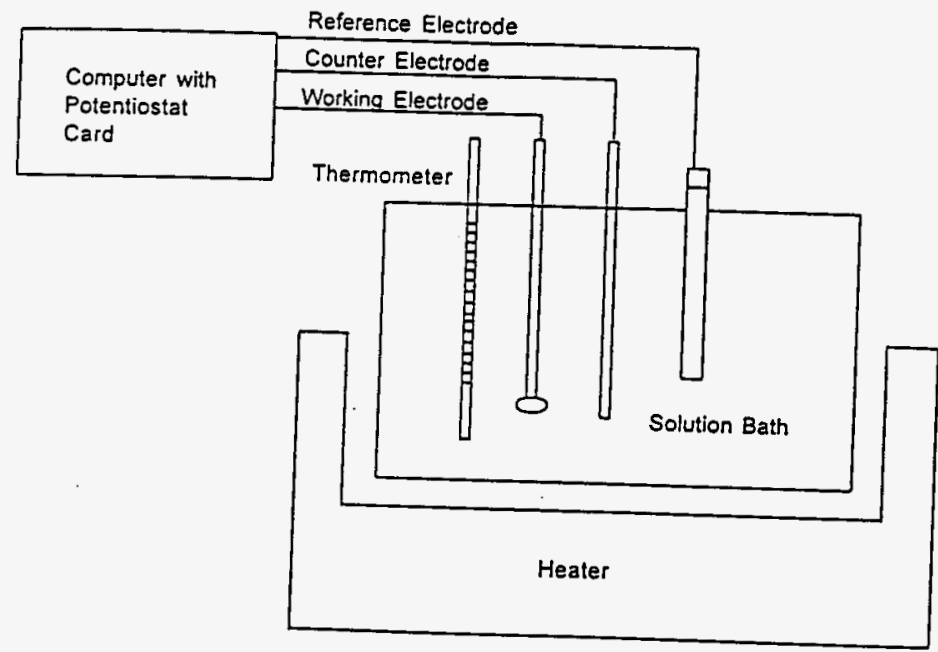

Figure 4. Schematic Showing Test Set-up for the Potentiodynamic Poiarization Tests. 
WHC-SD-WM-TI-765, Rev 0

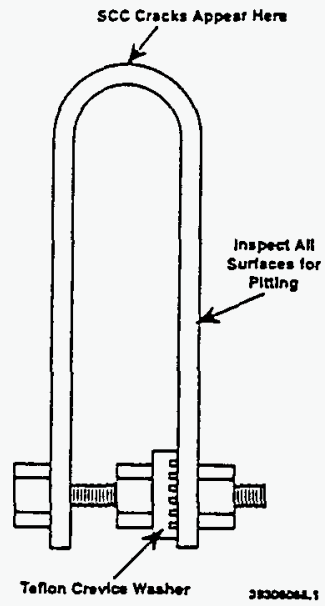

Figure 5. Configuration of the U-bend Specimen Used for Static Corrosion Testing. 


\subsection{EXPERIMENTAL RESULTS}

\subsection{SCC TESTING BY SLOW STRAIN RATE}

Ondrejcin (1984) used the slow strain rate method to explore the SCC behavior of carbon steels in nuclear waste environments. His data was used to define the safe/unsafe compositional operating regime for carbon steel waste tanks. Ondrejcin's test criterion for susceptibility to SCC was an elongation $\leq 13 \%$. SCC was intergranular in the slow strain rate tests. Table 5 shows the slow strain rate data in each of the 24 solutions and the air test for comparison. The elongation values were calculated from the load/displacement data. None of this elongation data meets the Ondrejcin (1984) criterion for susceptibility to SCC. In general, the elongation values were large, close to the value for the air test, implying that there was no SCC taking place in any of these test solutions. The lowest elongation value using the FY 95 test specimens was $17.4 \%$ in solution 12 . Solution 20 was a replicate of solution 12 , and the elongation value in that solution was $18.6 \%$. Solutions 12 and 20 were identical to a solution $(0.10 \mathrm{M}$ nitrite, $1.00 \mathrm{M}$ nitrate, and $0.10 \mathrm{M}$ hydroxide) used in the FY 94 slow strain rate test that clearly showed SCC by the Ondrejcin criterion ( $11.4 \%$ elongation). In order to investigate this discrepancy in elongation values between the FY 94 and FY 95 testing, an archival specimen from the FY 94 tests was tested in solution 12 at the usual strain rate of $1.3 \mathrm{E}-6 / \mathrm{sec}$. This time the elongation value for the FY 94 test specimen was $17.0 \%$, showing good agreement with the $17.4 \%$ elongation value found for the FY 95 specimen tested in solution 12. In order to ascertain whether the difference in elongation was due to the strain rate, a test was performed in solution 12 with a FY 95 test specimen at one-fourth the strain rate $(3.25 \mathrm{E}-7 / \mathrm{sec})$ normally used for the testing. The elongation from the test performed with the reduced strain rate was $15.2 \%$, a reduction in elongation but still above the Ondrejcin criterion for SCC. Carbon steel is not known to be strain rate sensitive, so the change in elongation would not be attributed to mechanical effects. The difference in elongation would suggest that additional time in the environment due to the reduced strain rate would lead to enhanced degradation in mechanical properties. The differences between the FY 94 and 95 SCC results raise a serious question about the usefulness of the slow strain rate test method for evaluating the propensity for SCC. 
WHC-SD-WM-TI-765, Rev O

Table 5. Slow Strain Rate Data.

\begin{tabular}{|c|c|c|c|c|c|}
\hline Solution & $\begin{array}{l}\text { Ultimate Load, } \\
\text { kN }\end{array}$ & Elongation, $\%$ & $\begin{array}{l}\text { Relative to air } \\
\text { Elongation. \% }\end{array}$ & $\begin{array}{l}\text { Reduction in } \\
\text { Area. } \%\end{array}$ & $\begin{array}{l}\text { Relative to air, } \% \\
\text { Reduction in }\end{array}$ \\
\hline Air & 24.9 & 20.8 & 100 & 34.8 & 100 \\
\hline 1 & 25.1 & 18.2 & 77 & 28.2 & 81 \\
\hline 2 & 23.6 & 21.8 & 92 & 35.6 & 102 \\
\hline 3 & 24.6 & 22.7 & 105 & 26.1 & 75 \\
\hline 4 & 22.2 & 19.2 & 101 & 27.9 & 80 \\
\hline 5 & 24.9 & 22.2 & 119 & 35.1 & 101 \\
\hline 6 & 24.9 & 22.7 & 121 & 28.6 & 82 \\
\hline 7 & 23.7 & 24.0 & 108 & 38.2 & 110 \\
\hline 8 & 25.4 & 24.5 & 104 & 31.8 & 91 \\
\hline 9 & 22.9 & 22.5 & 101 & 32.2 & 93 \\
\hline 10 & 26.2 & 23.5 & 95 & 30.8 & 89 \\
\hline 11 & 22.8 & 21.7 & 97 & 35.9 & 103 \\
\hline 12 & 24.5 & 17.4 & 93 & 18.5 & 53 \\
\hline 13 & 21.4 & 21.9 & 104 & 35.9 & 103 \\
\hline 14 & 24.8 & 21.0 & 95 & 33.2 & 95 \\
\hline 15 & 23.5 & 22.6 & 99 & 33.1 & 95 \\
\hline 16 & 23.6 & 22.8 & 99 & 30.7 & 88 \\
\hline 17 & 21.2 & 21.2 & 112 & 29.3 & 84 \\
\hline 18 & 20.9 & 22.8 & 111 & 30.8 & 89 \\
\hline 19 & 22.4 & 20.9 & 97 & 35.9 & 103 \\
\hline 20 & 22.6 & 18.6 & 90 & 20.7 & 59 \\
\hline 21 & 21.3 & 21.0 & 112 & 42.7 & 123 \\
\hline 22 & 24.2 & 20.1 & 90 & 24.8 & 71 \\
\hline 23 & 24.8 & 22.0 & 109 & 34.1 & 98 \\
\hline 24 & 23.9 & 20.8 & 119 & 28.8 & 83 \\
\hline $12^{*}$ & 20.1 & 17.0 & 83 & 10.4 & 30 \\
\hline $12+*$ & 233 & 15.2 & 71 & 15.5 & 45 \\
\hline
\end{tabular}

* Test performed with FY 94 specimen in solution 12

** Test performed with a FY 95 specimen at a strain rate of $3.25 \mathrm{E}-7 / \mathrm{sec}$ 
SEM photographs of the fracture surfaces at magnifications of $12 X$ and $100 X$ of the slow strain rate specimens are shown in Appendix $A$. A classic intergranular fracture appearance is not apparent for any of the specimens tested. The fracture surface appearance is not always consistent with complete ductile tearing, however. For example, there is a quasi-cleavage appearance to the fracture surface of the specimen tested a slower strain rate in solution 12, shown in Figure A.27b. Some specimens exhibited a reddishbrown corrosion product on the interior of the fracture surface that was not evident on the edges of the fracture surface. It is hypothesized that during the testing a small amount of the solution had siphoned into the interior of the fracture surface through a small crack in the gage section (implying that a crack opened early in the testing), leading to a fracture appearance as shown in Figure A.lla. Additionally, the FY 95 and FY 94 specimens tested in solution 20 (solution 12), including the specimen tested at the lower strain rate, showed evidence of secondary cracking readily observable at a magnification of $10 X$. This secondary cracking can be seen in the gage section shown in Figures A.7a, A.9a, A.10a, A.15a, A.21a, A.24a, and A.26a. A11 except for Figure A.10a represent fracture surfaces of specimens tested in low nitrite/nitrate ratio solutions or the presence of high chloride in the solution. Sludge-washing compositions that lead to secondary cracking are identified in the 1995 Test Matrix, Figure 6 . The presence of secondary cracking perpendicular to the applied stress during slow strain rate tests has been used as a criteria for SCC in some environments. This presents a dilemma in how to adequately characterize SCC for slow strain rate tests.

\subsection{POTENTIODYNAMIC PITTING TESTING}

The current-potential data from the pitting experiments are presented in Appendix B, Figures B.1 through B.24, for each of the twenty-four solutions. The solution composition, open circuit potential ( $E_{\text {corr }}$ ), pitting potential $\left(E_{p i t}\right)$, and protection potential ( $\left.E_{\text {prot }}\right)$ are reported in Table 6 . Briefly, a potentiodynamic pitting test is conducted in the following manner:

Starting at the open circuit corrosion potential, the electrochemical potential on the metal specimen is increased in the anodic direction at a constant rate $(0.2 \mathrm{mV} / \mathrm{s})$. The potential at the abrupt current increase is known as the pitting potential. In the case of the present tests, the potential scan is reversed at $1.0 \mathrm{~V}$ anodic to the open circuit potential, and the voltage is returned to the open circuit value at a rate of $0.2 \mathrm{mV} / \mathrm{s}$. When a metal starts to pit, the current increases abruptly, giving a characteristic signature. Once pits initiate and grow, they tend to persist so that the current remains high, causing the formation of a current hysteresis loop. During the reverse scan, the point at which the current decreases and becomes equal or less than the forward scan current is called the protection potential because the growth of the propagating pits is halted. The protection potential is thought to be the lowest potential that permits pitting to initiate; consequently, it has the greatest relevance for predicting pitting propensity for actual service. Figure B.19 illustrates how the pitting and protection potential are defined. At the low current ranges $\left(\leq 0.1 \mu \mathrm{A} / \mathrm{cm}^{2}\right)$, the logarithmic current amplifier in the potentiosat becomes noisy and creates the current spikes observed in the currentpotential data. 
On the basis of $E_{\text {prot }}$, six solutions were found to be capable of leading to pit initiation and propagation, as shown in Table 6 . However, these solutions are unlikely to cause pitting under actual field conditions because the $E_{\text {prot }}$ was at least $0.5 \mathrm{~V}$ anodic (more positive) than the open circuit potential. It would be unlikely that some condition in the tanks would ever result in the electrochemical potential of the tank wall becoming polarized into that regime.

The results from the static tests will be used to confirm the electrochemical results, but this data suggests that the tank waste can be diluted without generating pitting in the immersed tank steel. The other 18 solutions either appear benign to this carbon steel for pitting, or are susceptible to preferential general attack as the potential was increased, as in the case of the four high chloride solutions. Curiously, a small amount of crevice corrosion was observed in almost all cases underneath the polytetrafluorethylene gasket used to protect the electrical contact of the test electrodes. 
WHC-SD-WM-TI-765, Rev 0

Table 6. Pitting Experimental Data.

\begin{tabular}{|c|c|c|c|c|c|c|}
\hline Solutio & Nitrite, & Nitrate, & Hydroxide, $M$ & $E_{\text {cors }}$ & $E_{0 j+1}$ & $E_{\text {orotg }}$ \\
\hline 1 & 0.03 & 0.10 & 0.03 & -0.018 & NF & NF \\
\hline 2 & 0.01 & 0.10 & 0.03 & -0.032 & NF & NF \\
\hline 3 & 0.10 & 1.00 & 1.00 & -0.095 & +0.58 & +0.53 \\
\hline 4 & 0.30 & 1.00 & 0.10 & -0.025 & NF & NF \\
\hline 5 & 0.03 & 0.30 & 0.03 & -0.044 & NF & NF \\
\hline 6 & 0.03 & 0.10 & 0.01 & -0.093 & NF & NF \\
\hline 7 & 0.01 & 0.10 & 0.10 & -0.028 & NF & NF \\
\hline 8 & 0.30 & 1.00 & 0.30 & -0.039 & +0.57 & +0.36 \\
\hline 9 & 0.10 & 0.30 & 0.03 & -0.018 & NF & NF \\
\hline 10 & 0.01 & 0.10 & 0.01 & -0.054 & NF & $\mathrm{NF}$ \\
\hline 11 & 0.10 & 0.10 & 0.01 & -0.022 & NF & NF \\
\hline 12 & 0.10 & 1.00 & 0.10 & -0.109 & NF & NF \\
\hline 13 & 0.30 & 0.30 & 0.03 & -0.038 & NF & NF \\
\hline 14 & 0.10 & 1.00 & 0.30 & -0.092 & $\mathrm{NF}$ & $\mathrm{NF}$ \\
\hline 15 & 0.03 & 0.30 & 0.30 & -0.040 & +0.68 & +0.58 \\
\hline 16 & 0.03 & 0.30 & 0.10 & -0.030 & +0.74 & +0.71 \\
\hline 17 & 0.10 & 0.30 & 0.30 & -0.041 & +0.66 & +0.54 \\
\hline 18 & 0.10 & 0.30 & 0.10 & -0.110 & NF & NF \\
\hline 19 & 0.01 & 0.10 & 0.10 & -0.049 & +0.52 & +0.34 \\
\hline 20 & 0.10 & 1.00 & 0.10 & -0.038 & NF & $\mathrm{NF}$ \\
\hline $21^{\star}$ & 0.025 & 0.025 & 0.389 & -0.292 & NF & $\mathrm{NF}$ \\
\hline $22 *$ & 0.025 & 0.393 & 0.026 & -0.121 & NF & NF \\
\hline $23 *$ & 0.393 & 0.025 & 0.026 & -0.039 & NF & $\mathrm{NF}$ \\
\hline $24^{*}$ & 0.393 & 0.393 & 0.389 & -0.118 & NF & $\mathrm{NF}$ \\
\hline
\end{tabular}




\subsection{STATIC TESTS}

The static tests were started in March 1995 and terminated in September 1995 after a six month exposure. The specimens were then cleaned, weighed, and the data analyzed. The results are presented in Appendices $C, D, E$, and F.

Photographs shown in Appendix $C$ were taken of representative specimens from each test solution prior to cleaning. The U-bends and coupons from solutions $1,9,11,13$, and 18 exhibited shiny, post-test surfaces in the immersed phase, similar to the pre-test condition of the surface. One solution, solution 11 , exhibited a shiny post-test surface in the vapor phase.

Specimens exhibiting this surface condition also had the lowest average corrosion rates, as shown in the weight loss data of Appendix D. Specimens in solutions 1 and 13 exhibited a very thin, blue film in the post-test condition prior to cleaning. The composition of the film was not identified, but appears to be a thin, protective film easily removed with $\mathrm{CP}-9(10 \% \mathrm{HCl}$ with formaldehyde as the inhibitor) cleaning solution. Except for specimens immersed in solution 8 and the specimens in the high chloride solutions, the average uniform corrosion rate was highest for the solutions that had a 10:1 ratio of nitrate to nitrite. The specimens in the solutions that had a 10:1 ratio of nitrate to hydroxide and a $3.3: 1$ to $1: 1$ ratio of nitrate to nitrite had the lowest average corrosion rates measured.

The specimens were analyzed and photographed after cleaning in CP-9. Photographs of representative specimens, shown in Appendix $E$, were added as a visual aid to the interpretation. Measured values for the pitting density, size, and maximum depth, as well as the maximum depth of the crevice attack and waterline attack are listed in tabular form in Appendix F. Weight Toss coupons that were immersed in solutions 2, 5, 6, 10, and 22 are shown in Figures E.1, E.3, E.5, E.9, and E.12 because they showed unusual amounts of attack. For example, pronounced crevice attack is visible around the bolt hole in the specimens subjected to solutions $2,5,6,10$, and 22 . Weight loss specimens from the air/solution interface region from solutions $2,5,6$, 7 , and 10 are shown in Figures E.2, E.4, E.6, E.8, and E.10. These specimens exhibit either moderate pitting or a moderate to heavy amount of waterline attack, or a combination of the two. For comparison, a weight loss specimen immersed in solution 7 with a fairly pristine surface appearance is shown in Figure E.7. This specimen only exhibited light amounts of pitting and crevice attack, and is included for a visual reference point with respect to the specimens that exhibit moderate to heavy attack.

Photographs in Figures E.11 to E.18 were taken of representative specimens exposed to the high chloride solutions. Figure E.11 contains a photograph of a weight loss specimen that was immersed in solution 21 which exhibits a pristine appearance, and was included as a visual reference point. A photograph of a totally immersed weight loss specimen from solution 22 was included in Figure E.12 to show the extent of pitting in the high chloride solution. The pitting in solution 22 was far more extensive, both in area covered and in depth, than for solutions 21, 23, and 24 . All of the air/solution interface region specimens (weight loss and U-bend specimens) exhibited catastrophic levels of attack in the vapor phase region at and above the waterline. This can be very clearly seen in Figures E.13, E.14, E.16, E.17, and E.18. The specimen shown in Figure E.13 was accidentally dropped during the cleaning process, and a large chunk of brittle material broke away. 
It appears that the corrosion process converted that entire region of metal to oxide. It is interesting to note the vast difference in appearance between totaliy immersed U-bend specimens, as shown in Figure E.15, and those exposed to the air/solution interface, as shown in Figure E.16. The totally immersed specimen exhibited light amounts of pitting and crevice corrosion, whereas the partially immersed specimen exhibited massive attack at and above the waterline. The attack appears to be focused on the "wicking region" in the vapor phase where the 1 iquid phase is transported upwards by wetting the metal and oxide surface but at the same time is being diluted by downwards movement of condensation.

A tabular summary of the coupon tests observations was combined with the secondary cracking observations (from the slow strain rate tests) in Table 7 . Also included is the $\mathrm{pH}$ measured for each solution at the conclusion of the static tests. The test solution $\mathrm{pH}$ values ranged from 11.52 for solution 11 , one of the low hydroxide solutions, to 13.13 for solution 3 , which was the only solution with $1.0 \mathrm{M}$ hydroxide. Secondary cracking was observed in slow strain rate specimens tested in solutions $6,8,9,12,14,20$, and 23 (the specimen in solution 12 was a FY 94 test specimen, but solutions 12 and 20 are replicate solutions). Pitting was described in the table as light, moderate, or heavy, which corresponded to the pit density on the specimen (Light = $2.5 \mathrm{E} 3 / \mathrm{m}^{2}-1 \mathrm{E} 4 / \mathrm{m}^{2}$, Moderate $=5 \mathrm{E} 4 / \mathrm{m}^{2}$, Heavy $=1 \mathrm{E} 5 / \mathrm{m}^{2}$ ). (revice attack was, in a similar manner, described in the table as light, moderate, or heavy corresponding to the crevice attack area around the bolt hole. It was difficult to identify and measure the contributions to the massive attack on the specimens attributable to pitting and crevice corrosion, as the waterline attack had covered a large area of the specimen. Consequently, the pitting and crevice attack were not described, as above, for chloride-containing solutions 21 through 24 in the table, and the letters "Gr" were substituted to describe the gross general attack found on the specimens. Heavy pitting and crevice attack were noted for the immersed specimens in solution 22, which was a high chloride solution that contained a high concentration ratio of nitrate to nitrite as well as a high concentration ratio of nitrate to hydroxide. The other high chloride solutions contained levels of nitrite and hydroxide comparable to or higher than the nitrate concentration, and light pitting and crevice attack were observed for specimens immersed in these solutions.

A moderate amount of pitting and heavy crevice attack was observed for specimens immersed in solution 6 . Additionally, specimens immersed in solutions $1,2,5$, and 10 also exhibited heavy crevice attack. These solutions all have nitrate concentration levels between 0.1 to $0.3 \mathrm{M}$, and nitrite and hydroxide concentration levels between 0.01 to $0.03 \mathrm{M}$. Specimens immersed in the rest of the solutions exhibited only light amounts of pitting and crevice attack, or none at all. The pit density increased moderately for the specimens exposed to the vapor phase of solutions 7,10 , and 17 , and remained at a moderate amount for the specimens exposed to the vapor phase of solution 6. Crevice attack was moderate for specimens exposed to the vapor phase of solutions 2, 5, 7, and 12. Waterline attack was heavy for the specimens exposed to solutions 5 and 10 , and moderate for the specimens exposed to solutions $1,2,6$, and 12 . With the exception of solutions 7,12 , and 17 , the solutions again all have nitrate concentration levels between 0.1 to $0.3 \mathrm{M}$, and nitrite and hydroxide concentration levels between 0.01 to 0.03 M. Specimens exposed to the vapor phase in the rest of the solutions exhibited only light amounts of pitting and crevice attack, or none at all. 
The maximum depth of pitting, crevice attack, and waterline attack is shown in bar charts for the twenty-four solutions in Figures 7 through 11 . Sludge-washing compositions that lead to pitting, crevice, or waterline attack depth $\geq 0.05 \mathrm{~mm}$ were identified in the 1995 Test Matrix, Figure 12. Pitting depths, in general, were $<0.5 \mathrm{~mm}$ for specimens tested in both the immersed condition as well as the vapor phase of most of the solutions. This was not true for solutions $1,5,6$, and 10 , as well as for the high chloride solutions. The depth of the crevice attack was greater than for the pits in all solutions where both were present. The occurrence and density of pitting was greater for specimens in the vapor phase as compared to the immersed specimens, but the pits were often very shallow. Waterline attack was present on the specimens in the vapor phase for most of the solutions, with depths comparable to the depths of the crevice attack. A comparison of the corrosion coverage (pitting density, crevice attack area, or waterline attack area) versus the depth of the attack is given in Table 8 . There appears to be little correlation between the density of the attack and the depth of the attack for these solutions. 
Table 7. Visual 0bservations From Static Tests and Slow Strain Rate Tests.

\begin{tabular}{|c|c|c|c|c|c|c|c|c|}
\hline Solution & $\mathrm{pH}$ & $\begin{array}{l}\text { Immersed } \\
\text { Specimen, } \\
\text { Average } \\
\text { Corrosion Rate, } \\
\mathrm{mm} / \mathrm{y}\end{array}$ & $\begin{array}{l}\text { Secondary } \\
\text { Cracking }\end{array}$ & $\begin{array}{l}\text { Pitting - } \\
\text { Immersed }\end{array}$ & $\begin{array}{l}\text { Crevice - } \\
\text { Immersed }\end{array}$ & $\begin{array}{l}\text { Pitting - } \\
\text { Vapor }\end{array}$ & $\begin{array}{c}\text { Crevice - } \\
\text { Vapor }\end{array}$ & $\begin{array}{c}\text { Waterline } \\
\text { Attack - } \\
\text { Vapor }\end{array}$ \\
\hline 1 & 12.10 & $1.5 \mathrm{E}-3$ & & L & 8 & $\mathbf{L}$ & L & $\mathbf{M}$ \\
\hline 2 & 12.13 & $2.5 \mathrm{E}-3$ & & L & 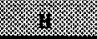 & $\mathbf{L}$ & M & $\mathbf{M}$ \\
\hline 3 & 13.13 & $5.0 \mathrm{E}-3$ & & & & & & \\
\hline 4 & 12.46 & $1.4 \mathrm{E}-3$ & & & & L & $\mathbf{L}$ & L \\
\hline 5 & 12.09 & $2.2 \mathrm{E}-3$ & & $\mathbf{L}$ & K & $\mathbf{L}$ & $\mathbf{M}$ & 3 \\
\hline 6 & 11.70 & $1.6 \mathrm{E}-3$ & x & $\mathbf{M}$ & \% & $\mathbf{M}$ & $\mathbf{L}$ & $\mathbf{M}$ \\
\hline 7 & 12.64 & $2.0 \mathrm{E}-3$ & & $\mathrm{~L}$ & $\mathrm{~L}$ & $\mathbf{M}$ & $\mathbf{M}$ & $\mathrm{L}$ \\
\hline 8 & 12.85 & $2.7 \mathrm{E}-3$ & xy & & & & & \\
\hline 9 & 12.02 & $2.2 \mathrm{E}-4$ & \% & L & $\mathrm{L}$ & L & $\mathbf{L}$ & $\mathbf{L}$ \\
\hline 10 & 11.85 & $7.7 \mathrm{E}-3$ & & $\mathbf{L}$ & 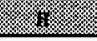 & $\mathbf{M}$ & $\mathrm{L}$ & \% \\
\hline 11 & 11.52 & 1.1E-5 & & & L & $\mathrm{L}$ & $\mathrm{L}$ & $\mathrm{L}$ \\
\hline 12 & 12.46 & $1.6 \mathrm{E}-3$ & / & $\mathrm{L}$ & $\mathbf{L}$ & $\mathbf{L}$ & $\mathbf{M}$ & $\mathbf{M}$ \\
\hline 13 & 12.02 & $2.0 \mathrm{E}-4$ & & & & $\mathbf{L}$ & & \\
\hline 14 & 12.88 & $2.6 \mathrm{E}-3$ & 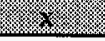 & & & $\mathrm{L}$ & $\mathrm{L}$ & $\mathrm{L}$ \\
\hline 15 & 13.00 & $4.6 \mathrm{E}-3$ & & & & $L$ & $\mathrm{~L}$ & $\mathrm{~L}$ \\
\hline 16 & 12.63 & $3.3 \mathrm{E}-3$ & & & $L$ & $\mathbf{L}$ & $\mathrm{L}$ & $\mathrm{L}$ \\
\hline 17 & 12.99 & 1.1E-3 & & & & $\mathbf{M}$ & $\mathrm{L}$ & \\
\hline 18 & 12.54 & $1.7 \mathrm{E}-4$ & & & & $\mathbf{L}$ & $\mathrm{L}$ & \\
\hline 19 & 12.67 & $2.2 \mathrm{E}-3$ & & $\mathbf{L}$ & $\mathrm{L}$ & $\mathbf{L}$ & L & $\mathbf{L}$ \\
\hline 20 & 12.50 & $2.1 \mathrm{E}-3$ & 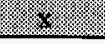 & $\mathrm{L}$ & & L & $\mathbf{L}$ & L \\
\hline 21 & 13.08 & $6.4 E-3$ & & & $\mathrm{~L}$ & s. & 4 & \% \\
\hline 22 & 12.61 & $2.4 \mathrm{E}-2$ & & 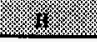 & 8xis & s. & \% & \% \\
\hline 23 & 12.75 & $3.8 \mathrm{E}-3$ & x & $\mathrm{L}$ & $\mathrm{L}$ & $x$ & \% & 8 \\
\hline 24 & 12.93 & $4.6 \mathrm{E}-3$ & & $\mathrm{~L}$ & $\mathrm{~L}$ & . & x. & 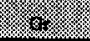 \\
\hline \multicolumn{9}{|c|}{$\begin{array}{l}\text { shaded cells highight areas of concern in the data set } \\
\text { * secondary cracking was found in the FY } 94 \text { specimen tested in solution } 12 \\
X=\text { identified on slow strain rate specimens tested in this solution } \\
\mathrm{L}=\text { light, } \mathrm{M}=\text { moderate, } \mathrm{H}=\text { heavy, (indicates pit density or crevice attack area) } \\
\text { Gr = not identified due to gross general attack in this region }\end{array}$} \\
\hline
\end{tabular}


Table 8. Comparison of Density of Attack With Depth of Attack.

\begin{tabular}{|c|c|c|c|c|c|}
\hline Solution & $\begin{array}{l}\text { Pitting - } \\
\text { Immersed }\end{array}$ & $\begin{array}{l}\text { Crevice - } \\
\text { Immersed }\end{array}$ & $\begin{array}{c}\text { Pitting - } \\
\text { Vapor }\end{array}$ & $\begin{array}{c}\text { Crevice - } \\
\text { Vapor }\end{array}$ & $\begin{array}{l}\text { Waterline } \\
\text { Attack - } \\
\text { Vapor }\end{array}$ \\
\hline 1 & L & y & 2 & . & $\mathbf{M}$ \\
\hline 2 & $\mathrm{~L}$ & 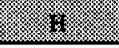 & $\mathrm{L}$ & 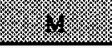 & $\mathbf{M}$ \\
\hline 3 & & & & & \\
\hline 4 & & & $\mathrm{~L}$ & $\mathrm{~L}$ & . \\
\hline 5 & $\sqrt{3}$ & 8 & L & 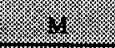 & 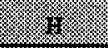 \\
\hline 6 & 1 & . & 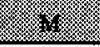 & 4 & . \\
\hline 7 & $\mathrm{~L}$ & . & $\mathbf{M}$ & , & . \\
\hline 8 & & & & & \\
\hline 9 & L & . & $\mathbf{L}$ & 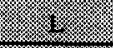 & L \\
\hline 10 & 1 & 4 & M & . & 柆 \\
\hline 11 & & . & $\mathrm{L}$ & 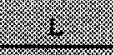 & L \\
\hline 12 & $\mathrm{~L}$ & $\mathrm{~L}$ & $\mathrm{~L}$ & 8 & . \\
\hline 13 & & & $\mathrm{~L}$ & & \\
\hline 14 & & & $\mathrm{~L}$ & $\mathrm{~L}$ & . \\
\hline 15 & & & $\mathrm{~L}$ & 柲: & $\mathrm{L}$ \\
\hline 16 & & $\mathrm{~L}$ & $\mathrm{~L}$ & L & 1) \\
\hline 17 & & & $\mathrm{M}$ & 格 & \\
\hline 18 & & & $\mathrm{~L}$ & 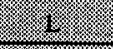 & . \\
\hline 19 & $\mathrm{~L}$ & . & $\mathrm{L}$ & , & $\mathrm{L}$ \\
\hline 20 & L & & L & 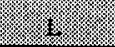 & $\mathrm{L}$ \\
\hline 21 & & . & (4) & 8 & $\sqrt{4}$ \\
\hline 22 & y & $\sqrt{13}$ & 8 & . & 8 \\
\hline 23 & 纹 & 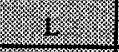 & 8. & (1) & 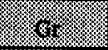 \\
\hline 24 & X. & (3) & (4) & 6 & 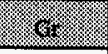 \\
\hline \multicolumn{6}{|c|}{$\begin{array}{l}\text { Cell shaded represent pitting, crevice, or waterline depth } \geq 0.05 \mathrm{~mm} \\
\mathrm{~L}=\text { light, } \mathrm{M}=\text { moderate, } \mathrm{H}=\text { heavy, (indicates pit density or crevice attack } \\
\text { area) } \\
\mathrm{Gr}=\text { not identified due to gross general attack in this region }\end{array}$} \\
\hline
\end{tabular}




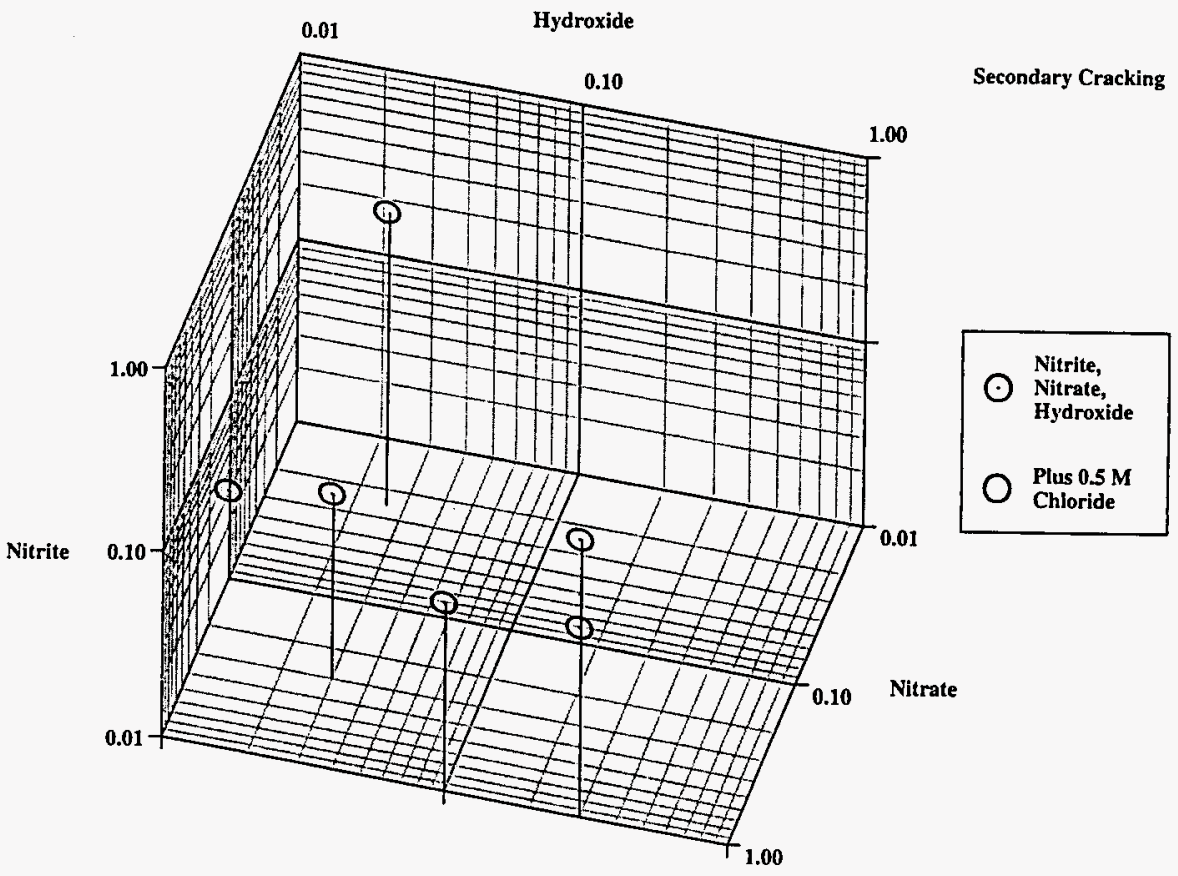

Figure 6. Sludge-Washing Compositions That Led to Secondary Cracking in 1995 Test Matrix. 
WHC-SD-WM-TI-765, ReV 0

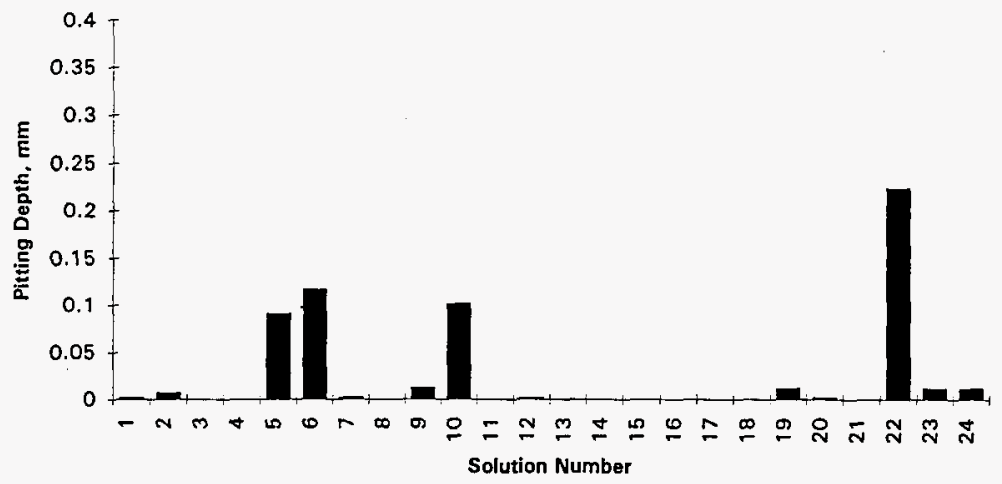

Figure 7. Maximum Pit Depth for Specimens Immersed in Solutions. 


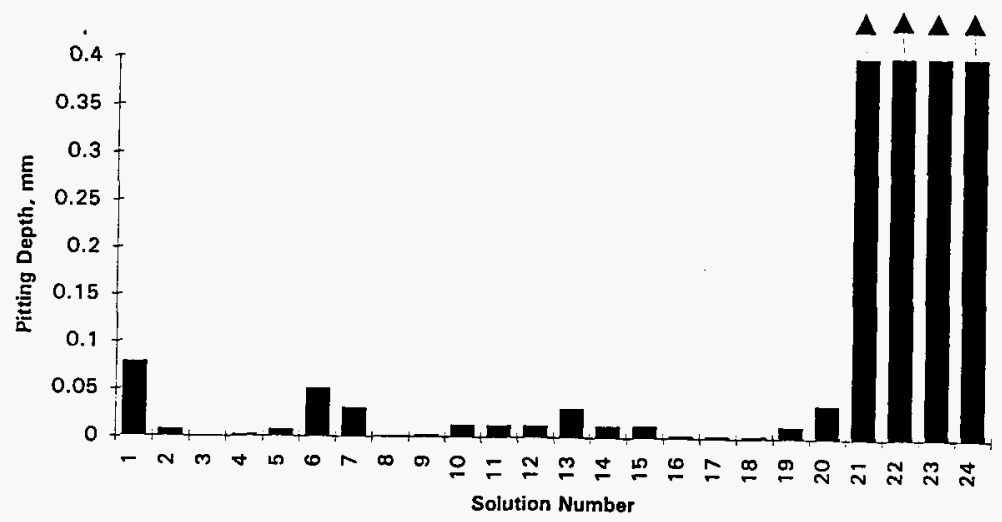

Figure 8. Maximum Pit Depth for Specimens in Vapor Phase. 


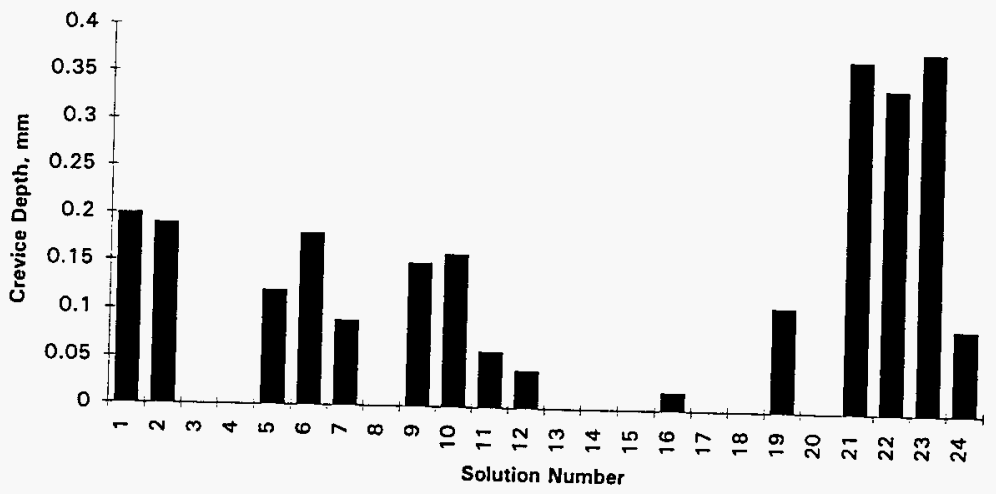

Figure 9. Maximum Depth of Crevice Attack in Immersed Specimens. 


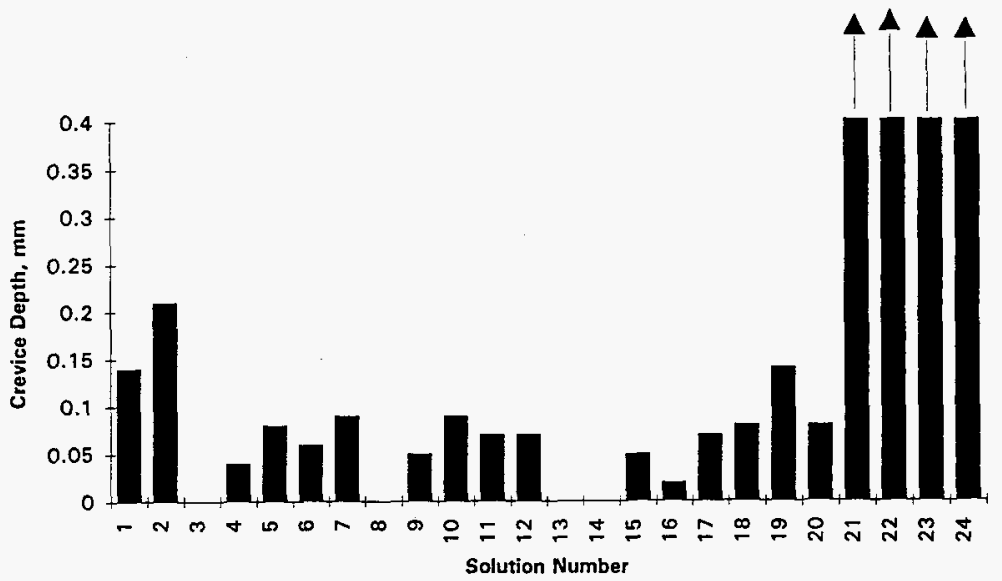

Figure 10. Maximum Depth of Crevice Attack in Vapor Phase Specimens. 


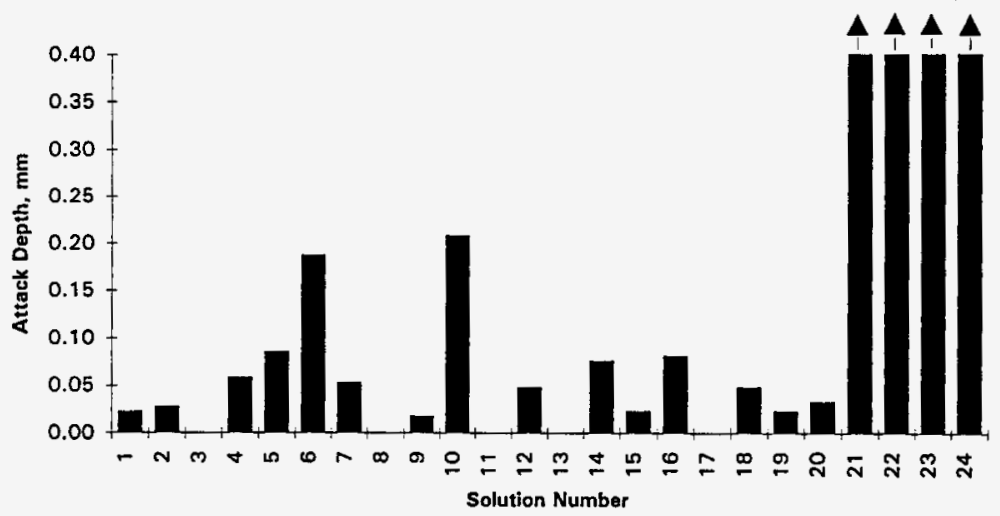

Figure 11. Maximum Depth of Waterline Attack in Vapor Phase Specimens. 


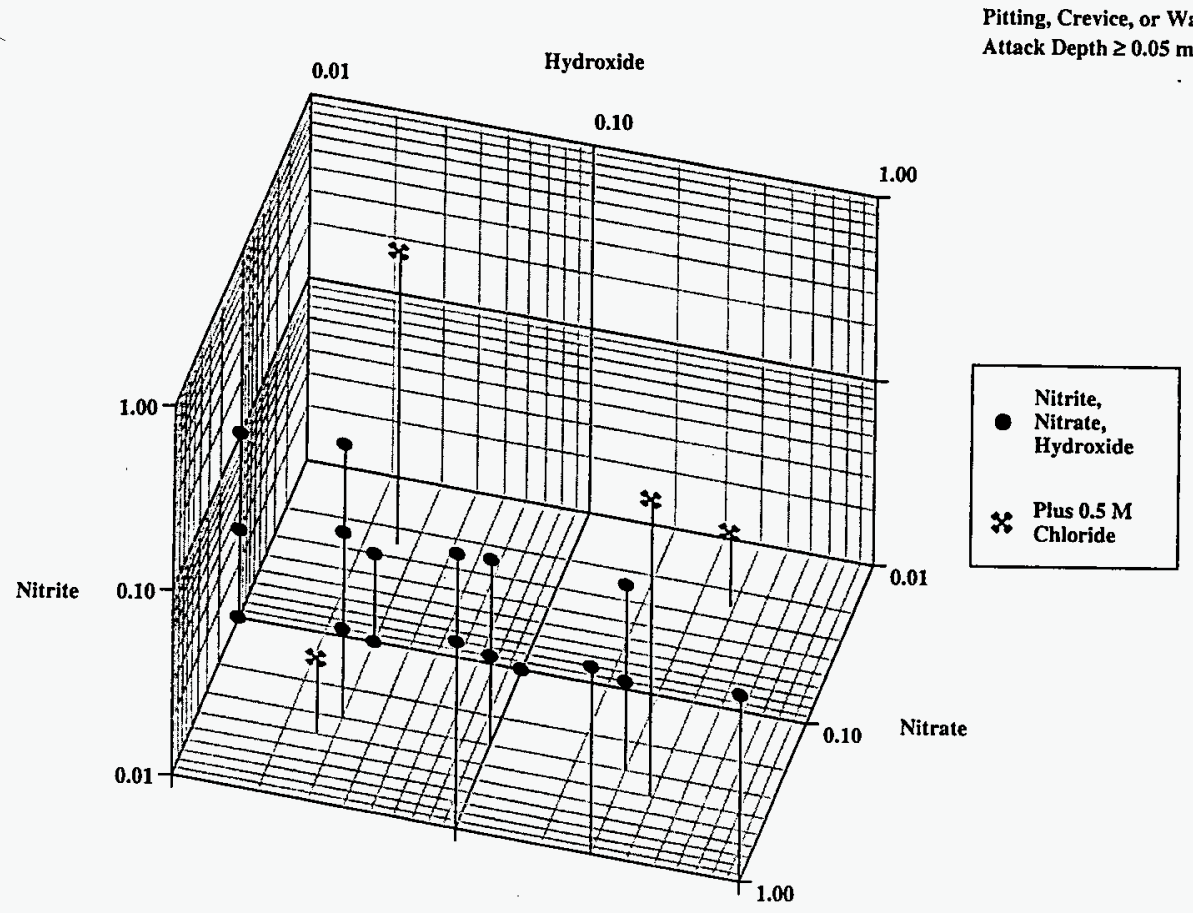

Figure 12. Sludge-Washing Compositions That Led to Pitting, Crevice, or Waterline Attack $\geq 0.05 \mathrm{~mm}$ in the 1995 Test Matrix. 


\subsection{DISCUSSION}

As in FY 94, three types of corrosion tests (static coupon tests, slow strain rate tests, and electrochemical tests) were performed in FY 95 to assess the susceptibility of ASTM A-515 Grade 60 carbon steel to failure by corrosion mechanisms. Whereas, the FY 94 testing was focused on scoping studies on the effects of dilute solutions containing hydroxide, nitrate and nitrite, the FY 95 testing was more tightly focused on (1) better paramatizing a troublesome FY 94 compositional regime, (2) enlarging the compositional regime to higher values of nitrate and nitrite, and (3) include the effects of chlorides which exist in several Hanford waste tanks. The specimens were tested in a statistically designed test matrix of twenty-four solutions at 93C in order to more completely evaluate the dilute waste regime. Following a six month exposure, the specimens were examined to determine their susceptibility to uniform corrosion, stress corrosion cracking, pitting, crevice corrosion, and waterline attack.

\subsection{EFFECTS OF CHLORIDES}

ASTM A-515 was very susceptible to various forms of localized corrosion (pitting, crevice, and waterline attack) in the high chloride solutions. Attack at and above the waterline was so pronounced (complete penetration of the specimen) that it was difficult to uniquely identify the contributions made by pitting, crevice, and uniform corrosion. This behavior is identified in Table 7 by the shaded cells for the vapor phase observations and the letter "Gr" indicating gross general attack. The greatest attack is above the waterline in a "wicking region" where the solution wicked upward by the porous oxide film is diluted by condensation. Thus, the attacked region is probably exposed to a diluted solution composition compared to what exists in the liquid phase. As the attack progresses and the oxide thickens, the attacked region will advance higher above the liquid level. The key insight to this phenomenon is that the totally immersed specimens had very little attack. Operation of the tanks within this range of process chemistry is not recommended due to the severe attack observed in this experimental series. Because the tests performed with high chloride concentrations were intended as scoping tests to look at the behavior of carbon steel tank material in simulated tank chemistries, information is only available for low chloride solutions (solutions $1-20$ ) and high chloride solutions $(21-24)$. The behavior of the carbon steel at intermediate chloride concentrations or whether there exists a threshold concentration for this chloride effect cannot be deduced from this study. Chlorides appeared to have no effect on SCC. 


\subsection{PITTING AND CREVICE CORROSION}

Pitting was observed on the specimens from many of the solutions, but as shown in Table 8 and in the tables in Appendix $F$, many of the pits were shallow and small in area. Crevice corrosion and waterline attack presented more of a problem as far as depth of attack and area of attack for many of the specimens, especially in the vapor phase. This corresponded to penetration rates from crevice attack of up to $0.38 \mathrm{~mm} / \mathrm{y}(0.19 \mathrm{~mm}$ over $6 \mathrm{mo})$ for specimens immersed in solution 2 and $0.42 \mathrm{~mm} / \mathrm{y}(0.21 \mathrm{~mm}$ over $6 \mathrm{mo})$ for specimens in the vapor phase of solution 2. Similar penetration rates were found for waterline attack, with up to $0.42 \mathrm{~mm} / \mathrm{y}(0.21 \mathrm{~mm}$ over $6 \mathrm{mo})$ measured for specimens in solution 10. At these rates, a $12.7 \mathrm{~mm}(1 / 2-i n$.$) steel tank wall would be$ penetrated in 30 years. Sludge washing operations should only expose the tank to these chemistries for under a year, so penetration due to localized corrosion processes is not expected to cause failure under these circumstances. Operation of the tanks under these chemistries for long periods of time, $>30$ years, would not be advisable due to the risk of throughwall penetration.

The potentiostatic polarization curves suggest that there is a propensity for pitting for certain potential ranges for immersed specimens in the dilute tank waste chemistry. The electrochemical potential at which pitting could occur, however, is too anodic for pitting to be found in the field, and this was confirmed by the static tests discussed in this report. Although there was a pitting potential identified for solutions 3, 8, 15, 16 , 17 , and 19, pitting was only observed on specimens tested in solution 19 and only light pitting was observed in that solution chemistry. The experimental results follow the same trend as the pitting tests in a dilute waste chemistry regime carried out at the Savannah River Laboratory (Zapp 1988a, 1988b, 1989a, $1989 \mathrm{~b})$. Both studies indicate pitting is associated with a low nitrite/nitrate ratio, although pitting was not observed for all solutions containing the low nitrite/nitrate ratio.

\subsection{UNIFORM CORROSION}

The uniform attack data for the totally immersed specimens is shown in Table 7. Except for the chloride-containing solutions, all the uniform attack rates are below $5.1 \mathrm{E}-3 \mathrm{~mm} / \mathrm{y}(0.2 \mathrm{mpy})$, making this mode of degradation unimportant. Two of the chloride solutions resulted in higher rates, but the localized attack associated with the chloride solutions dwarfs any uniform attack problems. 


\subsection{STRESS CORROSION CRACKING}

All of the FY 95 slow strain rate (SSR) tests had elongations greater than Ondrejcin's criterion of $\leq 13 \%$ elongation for SCC. In other words, none of the 24 solutions demonstrated an ability to cause SCC of ASTM A-515 carbon steel. Examination of the fracture surfaces of the slow strain rate specimens did not definitively indicate SCC for any of the solution chemistries, but areas exist on the surfaces of some specimens that differ from the appearance of ductile failure. However, there were some disturbing observations in the test data that leads one to believe that the SSR technique is not adequately conservative for predicting SCC behavior:

1. Secondary cracking was noted on the gage lengths perpendicular to the applied stress for specimens that were tested in seven solutions: 6,8 , $9,12,14,20$, and 23 .

2. Solutions 12 and 20 indicated no SCC by the ondrejcin criterion, but these were duplicates of a solution ( $\$ 2)$ that indicated SCC (11\% elongation) in the FY 94 testing. When the strain rate was decreased by $1 / 4$, the elongation decreased but was still above the Ondrejcin criterion.

Secondary cracking on the slow strain rate specimens also occurred, with one exception, for solutions with either a 10:1 ratio of nitrate to nitrite or a 10:1 ratio of both nitrate to nitrite and nitrate to hydroxide. The exception was solution 6 , which has a low concentration of nitrate with a $3.3: 1$ ratio of nitrate to nitrite and $10: 1$ ratio of nitrate to hydroxide. The specimens in the solutions that had a 10:1 ratio of nitrate to hydroxide and a $3.3: 1$ to $1: 1$ ratio of nitrate to nitrite had the lowest average corrosion rates measured.

Determination of SCC susceptibility is not always straightforward, and often shallow SCC penetrations are difficult to interpret in SEM photographs. Shallow penetrations are associated with borderline SCC conditions between those that cause severe SCC and those that cause no SCC (Payer et al. 1977). In addition, other factors that measure the ductility of the specimen, such as elongation and reduction of area, are considered in conjunction with the fracture surface appearance to determine SCC susceptibility. Another feature that contributes to the confirmation of SCC susceptibility is the presence of secondary cracking perpendicular to the applied stress along the gage length. Additionally, the severity of SCC is a function of the strain rate. Payer et a). (1975) suggested that there exists a critical range of strain rate for which the severity of SCC is at a maximum. Too high a strain rate will result in a ductile failure of the specimen from mechanical overload, even without the effect of environmental effects. Too slow of a strain rate will allow repassivation of the crack tip, and will suppress the SCC (Payer et a1. 1975). The incidence of secondary cracking was noted as a suspicious finding, and it would be recommended to avoid such chemistries during the sludge washing operation as a conservative measure. 
Variations in test data from FY 94 when compared to data in the current year's tests may also result from minor changes in the material chemistry of the specimens. Corrosion susceptibility has been found to differ for minor variations of the levels of constituents (such as sulfur and phosphorus), even within the same ASTM specification and grade of a material. It is not entirely clear how much variation in corrosion susceptibility can be expected from slight changes in the minor constituents of the carbon steel. In the absence of a such a correlation, the best results can be obtained by procuring material for corrosion testing that is as close to the tank steel chemistry specifications as is reasonably possible. Waste tanks at Hanford were constructed with older steels that are "dirty" compared to modern steels (modern steels were used in this testing program). 0lder steels probably contained sulfur levels of about $0.02 \mathrm{wt} \%$ and phosphorus levels of about 0.013 wt\% (Schwenk and Scott 1996). Steels used for specimens in FY 94 and FY 95 testing contained $0.013 \mathrm{wt} \%$ and $0.015 \mathrm{wt} \%$ sulfur, respective $1 \mathrm{y}$, and $0.023 \mathrm{wt} \%$ and $0.008 \mathrm{wt} \%$ phosphorus, respectively. Yield stress values for the tank steel were reported to average $303 \mathrm{MPa}$ compared to values of $405 \mathrm{MPa}$ and 341 MPa reported for the FY 94 and FY 95 specimens respectively. Repeated attempts to procure representative "dirty" steels from steel mills did not meet with success and no archival tank material was located, so the available steel lots with the highest levels of sulfur and phosphorus were purchased for each year's testing. Tests performed with the "cleaner" steels may not be adequately conservative to assess the corrosion susceptibility due to the enhanced susceptibility of the "dirty" steels to environmental degradation. Therefore, some error is introduced into the testing by using "cleaner" steels, but solution chemistries that indicate corrosion problems for the "cleaner" steels should certainly be avoided in the tank waste environment that contains the "dirtier" steels.

\subsection{RECONMENDATIONS FOR FUTURE WORK}

Corrosion testing that has been performed in FY 94 and FY 95 to support sludge washing operations has identified compositional regimes that should be avoided during tank dilution. An important question remains, however, about how well the "cleaner" steels model the corrosion susceptibility of the "dirtier" steels that the tanks were fabricated from. In addition, a scoping study on the effects of chloride on the susceptibility of the tank steel to corrosion has produced unexpectedly high levels of corrosive attack on the test specimens. The chloride level that was chosen for the tests was considered an upper bound for the chloride levels in the Hanford waste tanks (Certa et al. 1993), and a more likely concentration of chloride in the tanks would fall somewhere between the $0.5 \mathrm{M}$ and the $30 \mathrm{mg} / \mathrm{L}$ extremes used in this round of testing. The following recommendations are made for future work:

1. Additional testing should be performed to assess the levels of chloride that lead to pronounced levels of attack, and identify a threshold level, if one exists, to operate the process chemistry below. 
2. It is the opinion of the authors that every attempt should be made to procure "dirty" steels that are more representative of the actual tank steel chemistry. Procurement of sufficiently "dirty" steels for future tests may require a custom mill run to specifically alloy the steel, procurement of archival materials used in tank fabrication, or an exhaustive search by a materials vendor. The first suggestion may be prohibitly expensive, the second suggestion has been attempted with little success, and the third suggestion seems like the reasonable option at this time.

3. The experimental results should be evaluated by a statistician.

\subsection{CONCLUSIONS}

Specimens of A515 steel were tested in solutions representative of anticipated sludge-wash chemistries using the slow strain rate method, electrochemical testing, and static testing using U-bends and corrosion test coupons. The following conclusions were obtained from the experimental results:

1. The ductility of many of the specimens, as measured by reduction of area, was slightly lower in aqueous tank chemistries, on average, than in air. The effect of environment of elongation varied from. $+3.7 \%$ to $3.4 \%$. The elongations for the high chloride specimens were uniformly high.

2. The observed small decrease in ductility could not be unambiguously associated with $\mathrm{SCC}$, as there was no definitive change in fracture morphology from microvoid coalescence to inter- or transgranular fracture. For this reason, the decrease in ductility may be associated with another, more benign, embrittlement mechanism. Secondary cracks were found in the gage lengths of some specimens, however, which would indicate a propensity towards SCC.

3. The mechanical behavior of the tank steel was affected by the strain rate, with those specimens tested at the lowest strain rate exhibiting the lowest ductility. This strain-rate dependence indicates that the mechanism responsible for the observed embrittlement is environmental, rather than mechanical. There may exist a critical strain rate for this material for which this material is highly susceptible to SCC that has not been evaluated.

4. Although a propensity for pitting was indicated in six test solutions, the electrochemical potential at which pitting could occur was too anodic for pitting to be expected to occur in the field. This was, for five of the six solutions, confirmed by the pitting observed in the static tests. Pitting was observed for many of the solution chemistries, but pit depth was $<0.05 \mathrm{~mm}$ for most of the observed pits. 
5. Crevice corrosion was observed on the specimens for many of the solution chemistries in the immersed phase and most of the solution chemistries in the vapor phase, with a crevice depth of up to $0.21 \mathrm{~mm}$ established over a six month period. Waterline attack was also observed for most solution chemistries, and with measured depths comparable to the crevice attack.

6. Severe corrosion attack was observed for the air/solution interface specimens tested in the high chloride solutions, solutions 21 through 24. There was a significant amount of metal loss associated with the corrosion processes, and the area of greatest attack was at and just above the waterline. The severe corrosion left the specimens in a brittle state, as was evidenced by the fracture of a specimen that was inadvertently dropped during the cleaning operations.

7. Recommendations are made to avoid the solution chemistries during sludge washing that produce secondary cracking during slow strain rate testing or gross general attack as that observed in the high chloride solutions. Heavy crevice, pitting, or waterline attack has been observed for some of the solution chemistries, but through-wall penetration for the deepest attack is calculated at 30 years. Although the depth of attack can be considered significant, sludge washing operations are only expected to keep the tanks in the modified chemistry for less than one year, so failure due to these corrosion processes is not expected.

8. A discrepancy was noted between this and earlier work (Danielson and Bunnell 1994) with regard to the SSR results. It is suspected that the lower ductility observed in the earlier work is due to higher sulfur and phosphorus contents of the material used previously. If this theory is correct, it would indicate that the current tests may be nonconservative in evaluating the performance of the double-shell tank steels, which were made using production techniques that are no longer used. On the other hand, the stress-relieving heat treatment used in the current work would tend to make the material more susceptible to SCC, resulting in more conservative test results. 


\subsection{REFERENCES}

ASTM, 1990, American Standards for Testing Materials, Wear and Erosion; Metal Corrosion, Volume 3.02, G-1, Practice for Preparing, Cleaning, and Evaluation Corrosion Test Specimens, pp. 39-45, G-3, Practice for Conventions Applicable to Electrochemical Measurements in Corrosion Testing, pp. 60-65, G-5, Reference Test Method for Making Potentiostatic and Potentiodynamic Anodic Polarization Measurements, pp. 77-81, G-30, Standard Practice for Making and using U-bend Stress Corrosion Test Specimens, pp. 100-105, G-31, Practice for Laboratory Immersion Corrosion Testing of Metals, pp. 106-113, G-46, Standard Practice for Examination and Evaluation of Pitting Corrosion, pp. 170-176, Philadelphia, Pennsylvania.

Danielson, M. J. and L. R. Bunnel1, 1994, Sludge Washing Materials Study: The Behavior of Carbon Steel in a Dilute Waste Environment, PNL-10097, Pacific Northwest Laboratory, Richland, Washington.

Kirch, N. W., 1984, Technical Basis for Waste Tank Corrosion Specifications, SD-WM-TI-150, Rockwell Hanford Operations, Richland, Washington.

Memo, 1993, P. J. Certa, J. R. Divine, and M. J. Kupfer to J. M. Light, Recommended Waste Composition Change to the MWTF FDC, Westinghouse Hanford Company, Richland, Washington.

Ondrejcin, R. S., 1977, Investigation of Cooling Coi7 Corrosion in Radioactive-Waste Storage Tanks, DP-1425, E. I. Dupont de Nemours and Company, Savannah River Laboratory, Aiken, South Carolina.

Ondrejcin, R. S., 1978, Prediction of SCC of Carbon Steel by Nuclear Process Liquid Wastes, DP-1478,

E. I. Dupont de Nemours and Company, Savannah River Laboratory, Aiken, South Carolina.

Ondrejcin, R. S., 1984, Prevention of Stress Corrosion Cracking in Nuclear Waste Storage Tanks, Paper 258, CORROSION/84, April 2-6, 1984, New Orleans, Louisiana.

Payer, J. H., W. E. Berry, and W. K. Boyd, 1977, Stress Corrosion Cracking: The Slow Strain Rate Technique, STP 665, American Society for Testing and Materials, Philadelphia, Pennsylvania.

Payer, J. H., W. E. Berry, and W. K. Boyd, 1975, Stress Corrosion - New Approaches, STP 610, American Society for Testing and Materials, Philadelphia, Pennsylvania.

Sarafian, P. G., 1975, The Influence of Microstructure on Stress Corrosion Cracking of Mild Steel in Synthetic Caustic-Nitrate Nuclear Waste Solution, Ph.D. Thesis at Georgia Institute of Technology, Atlanta, Georgia.

Schwenk, E.B., and K.V. Scott, 1996, Description of Double-Shell Tank Selection Criteria for Inspection, WHC-SD-WM-ER-529, Rev. 0, Westinghouse Hanford Company, Richland, Washington. 
Zapp, P. E., 1988a, Electrochemical Study of Corrosion Inhibition During Sludge Washing, Memorandum DPST-88-399, Savannah River Laboratory, Aiken, South Carolina.

Zapp, P. E., 1988b, Coupon Immersion Test for Corrosion Inhibition of Washed Sludge, Memorandum DPST-88-680, Savannah River Laboratory, Aiken, South Carolina.

Zapp, P. E., 1989a, Effect of Temperature on Nitrite Inhibitor Requirements of Washed Precipitate Slurry, Memorandum WSRC-RP-89-24, Savannah River Laboratory, Aiken, South Carolina.

Zapp, P. E., 1989b, Inhibition of Sludge Suspensions Containing High Concentrations of Aggressive Anions, Memorandum WSRC-RP-89-430, Savannah River Laboratory, Aiken, South Carolina. 
WHC-SD-WM-TI-765, Rev 0

APPENDIX A: SEM PHOTOGRAPHS OF SLOW STRAIN RATE SPECIMEN FRACTURE SURFACES

A- $\mathbf{i}$ 


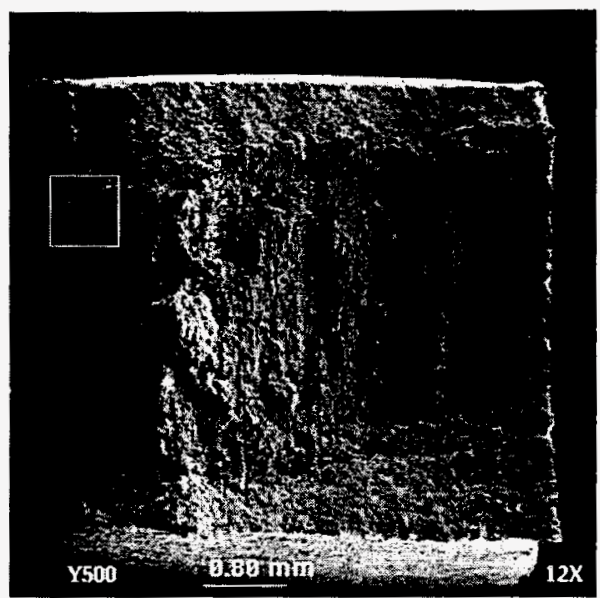

Figure A.1a. Fracture of Specimen from Air

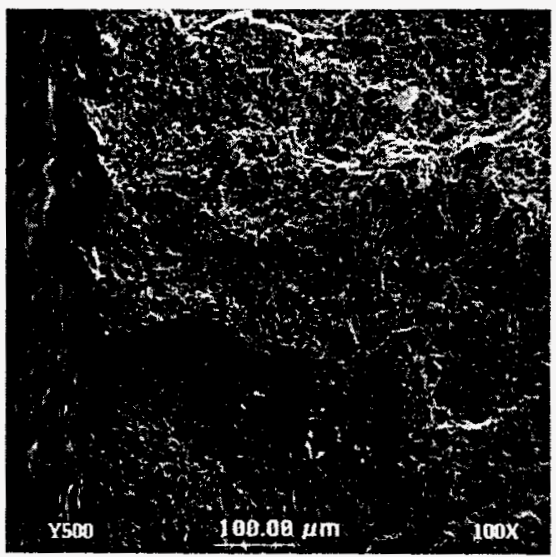

Figure A.1b. Higher Magnification of Fracture Surface 


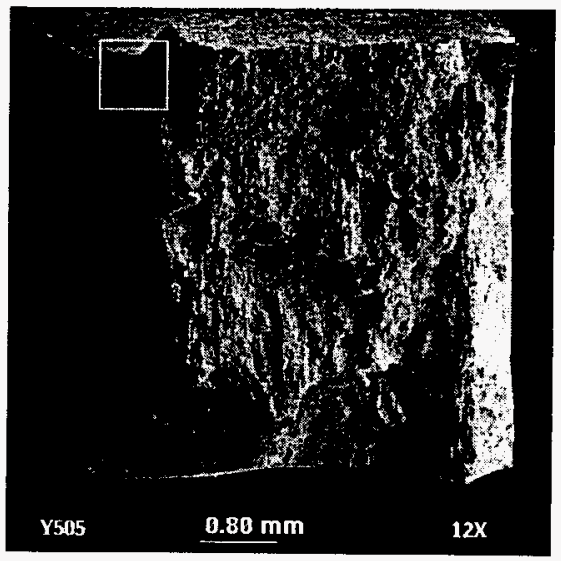

Figure A.2a. Fracture of Specimen from Solution 1

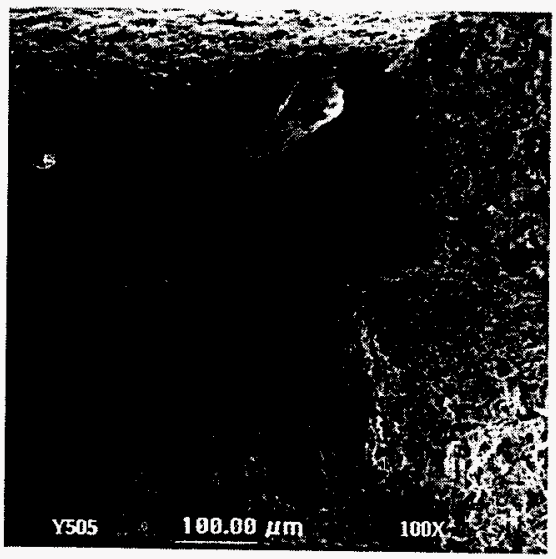

Figure A.2b. Higher Magnification of Fracture Surface 
WHC-SD-WM-TI-765, Rev 0

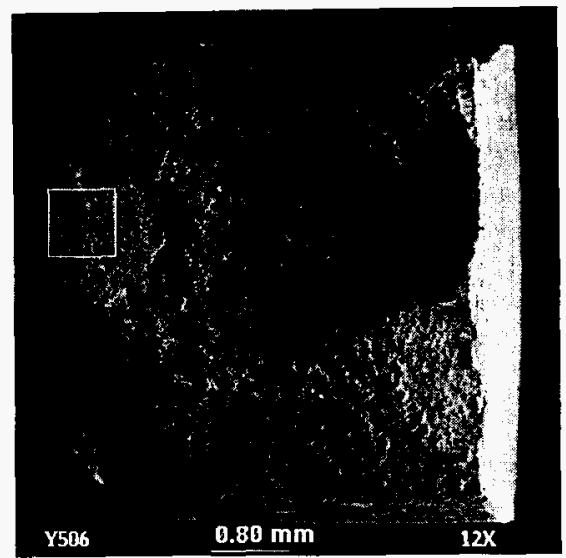

Figure A.3a. Fracture of Specimen from Solution 2

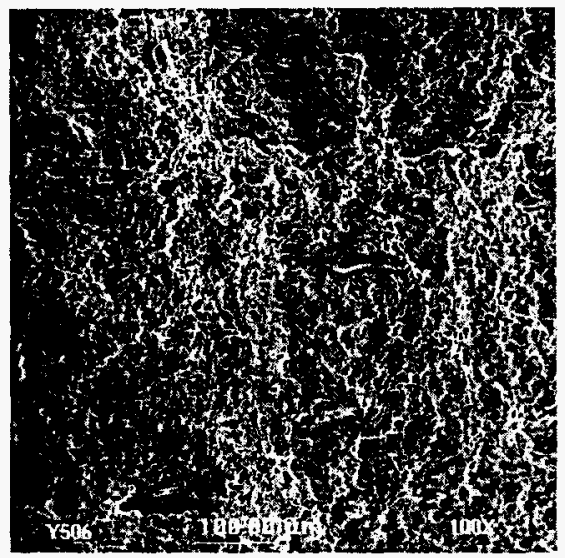

Figure A.3b. Higher Magnification of Fracture Surface 


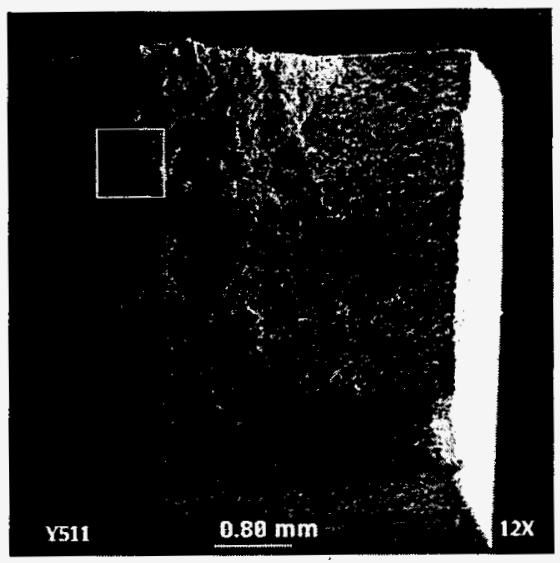

Figure A.4a. Fracture of Specimen from Solution 3

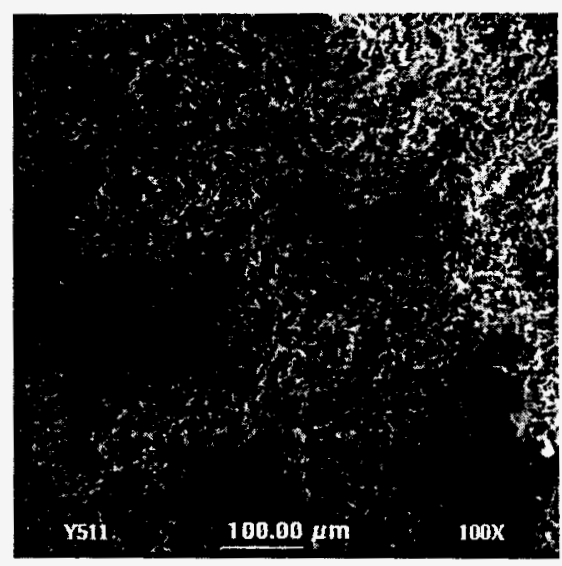

Figure A.4b. Higher Magnification of Fracture Surface 


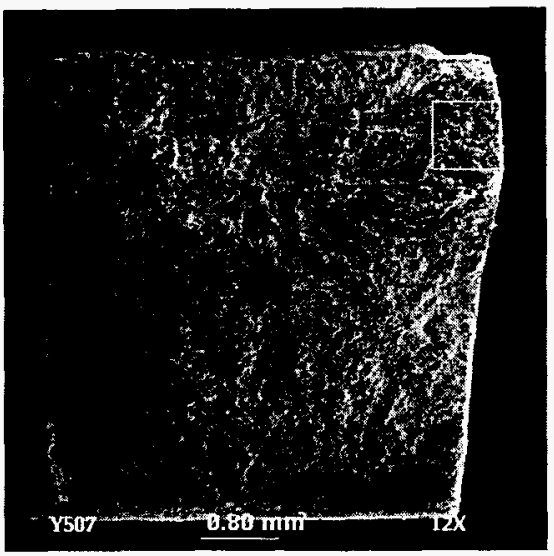

Figure A.5a. Fracture of Specimen from Solution 4

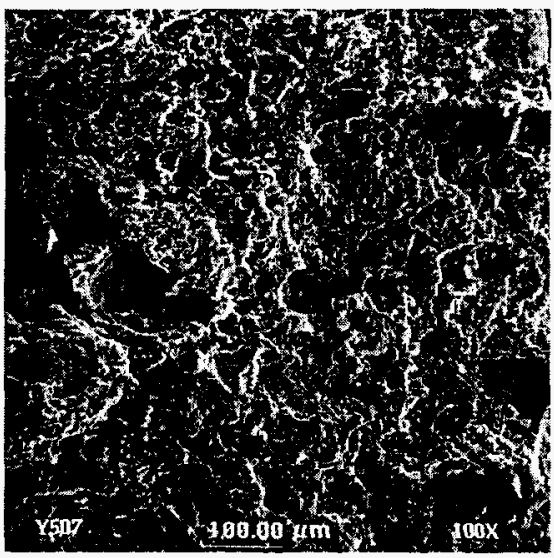

Figure A.5b. Higher Magnification of Fracture Surface 


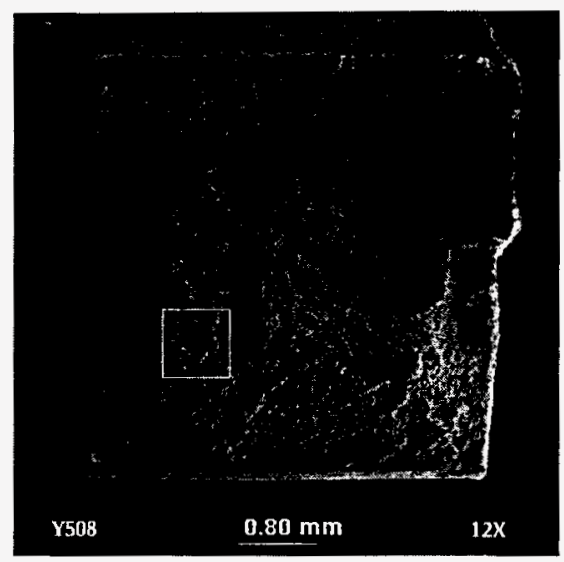

Figure A.6a. Fracture of Specimen from Solution 5

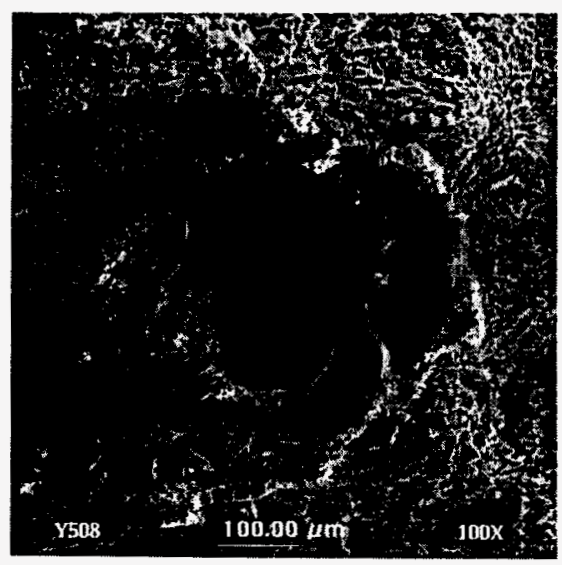

Figure A.6b. Higher Magnification of Fracture Surface 
WHC-SD-WM-TI-765, Rev 0

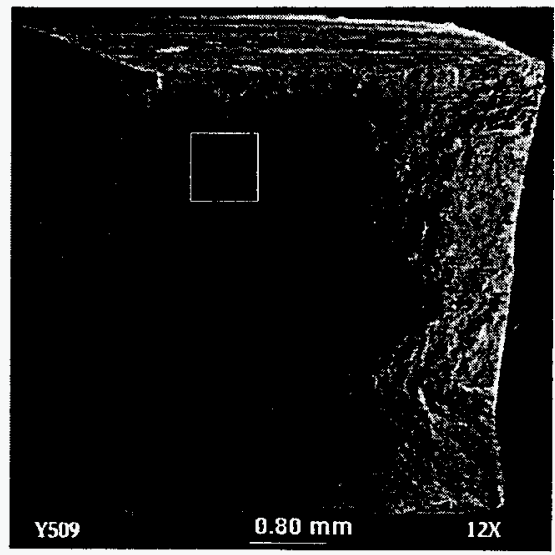

Figure A.7a. Fracture of Specimen from Solution 6

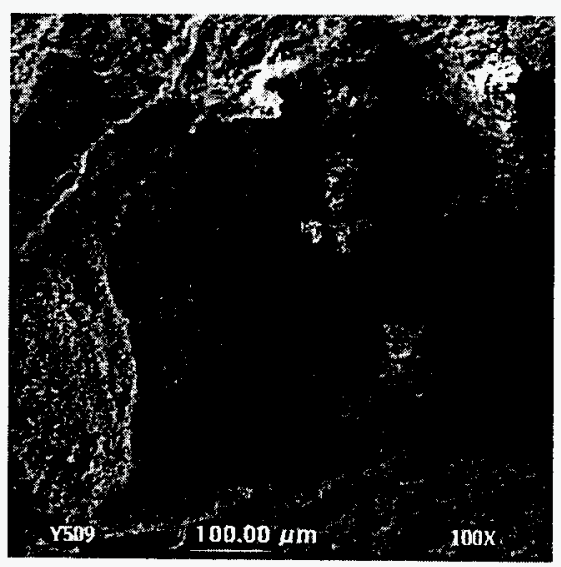

Figure A.7b. Higher Magnification of Fracture Surface 


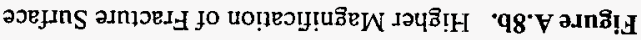

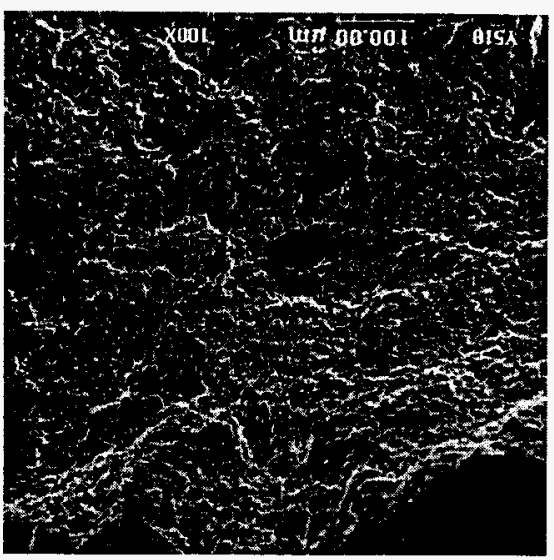

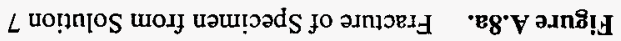

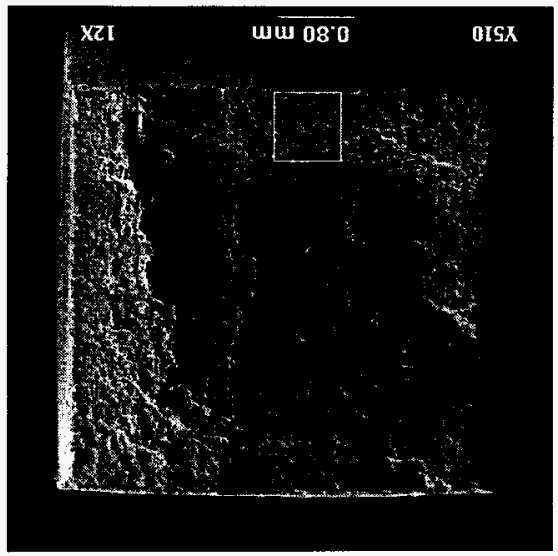


WHC-SD-WM-TI-765, Rev 0

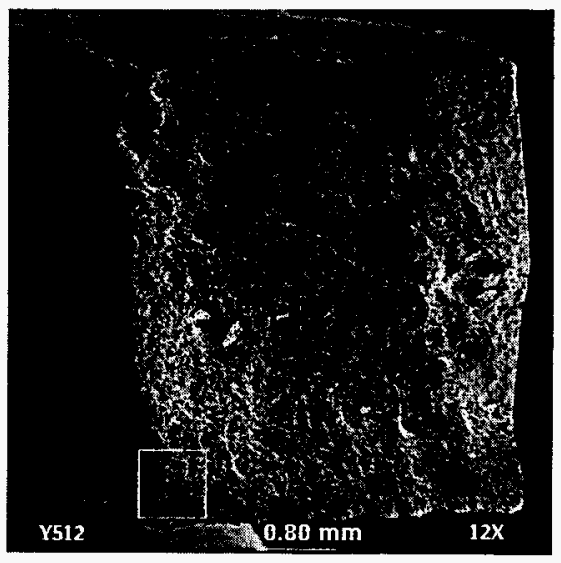

Figure A.9a. Fracture of Specimen from Solution 8

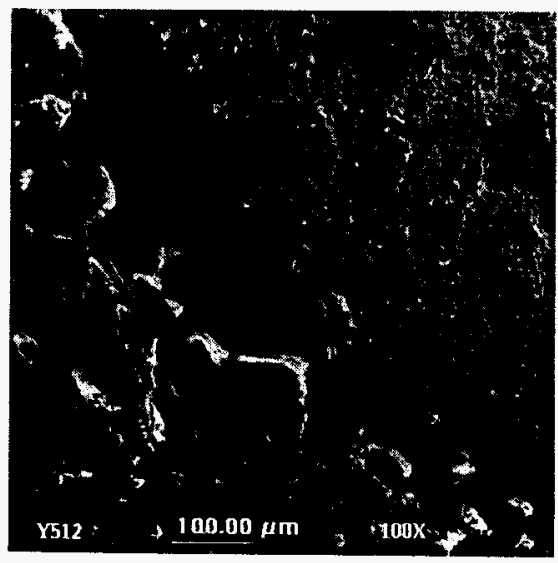

Figure A.9b. Higher Magnification of Fracture Surface 


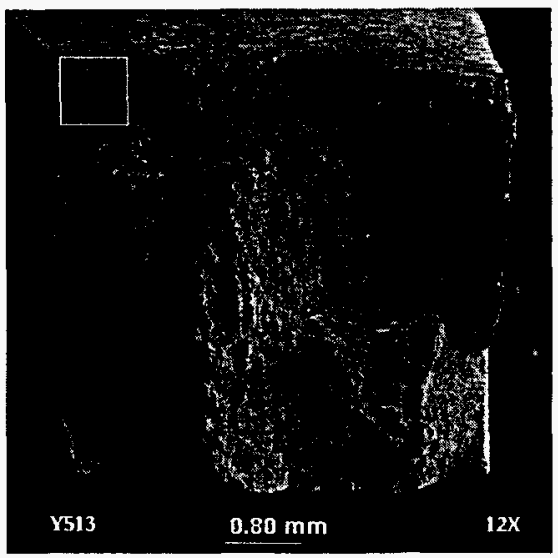

Figure A.10a. Fracture of Specimen from Solution 9

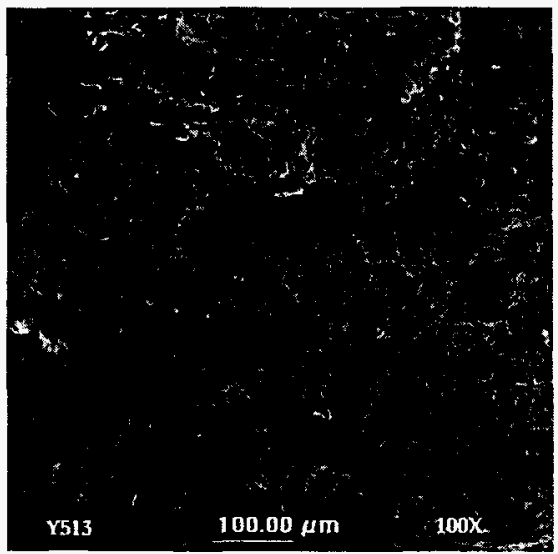

Figure A.10b. Higher Magnification of Fracture Surface 


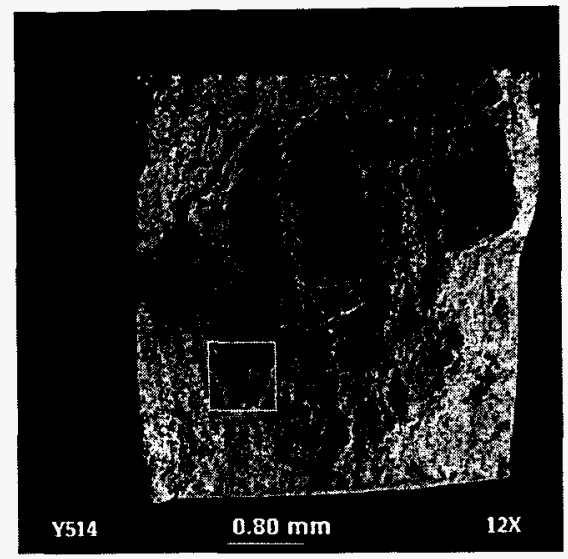

Figure A.11a. Fracture of Specimen from Solution 10

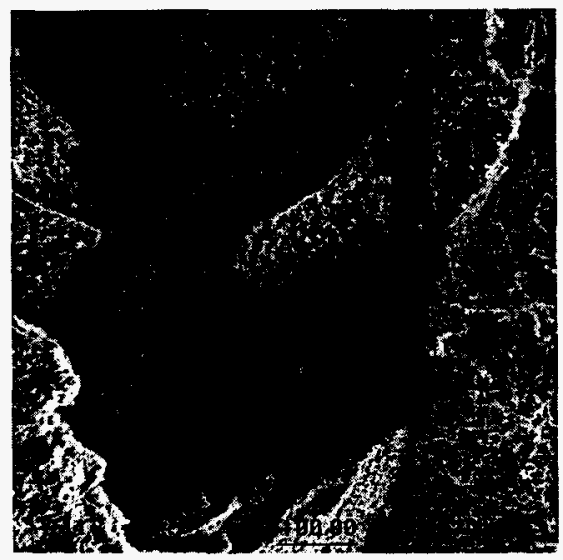

Figure A.11b. Higher Magnification of Fracture Surface 


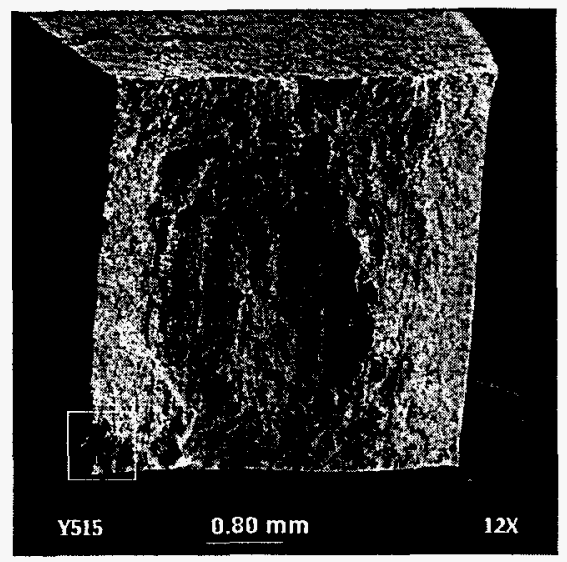

Figure A.12a. Fracture of Specimen from Solution 11

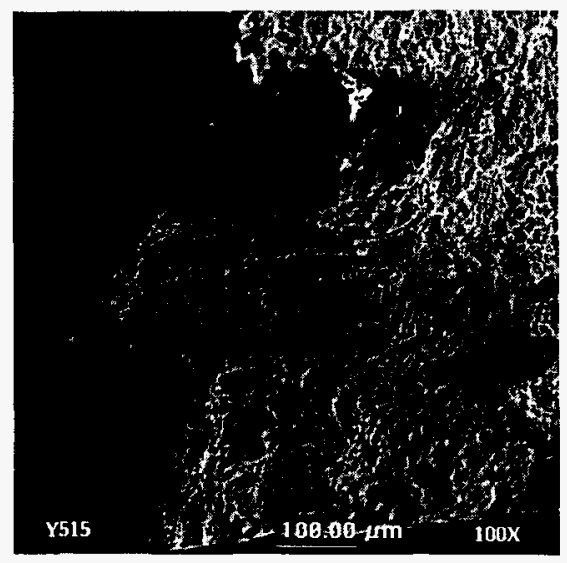

Figure A.12b. Higher Magnification of Fracture Surface 
WHC-SD-WM-TI-765, Rev 0

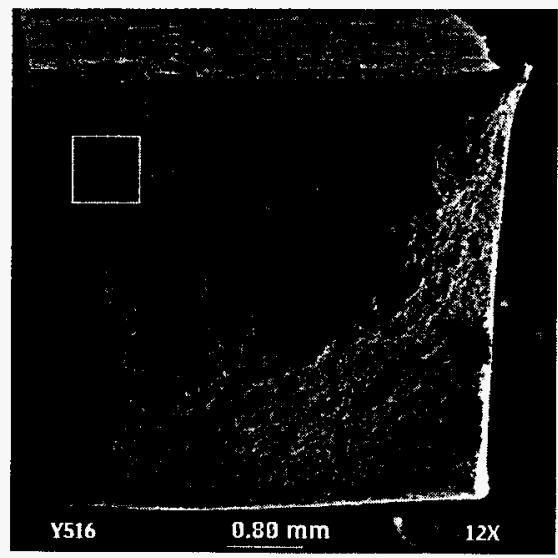

Figure A.13a. Fracture of Specimen from Solution 12

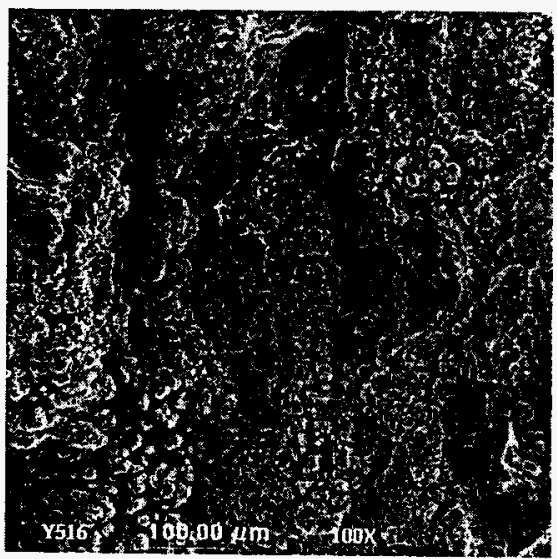

Figure A.13b. Higher Magnification of Fracture Surface 
WHC-SD-WM-TI-765, Rev 0

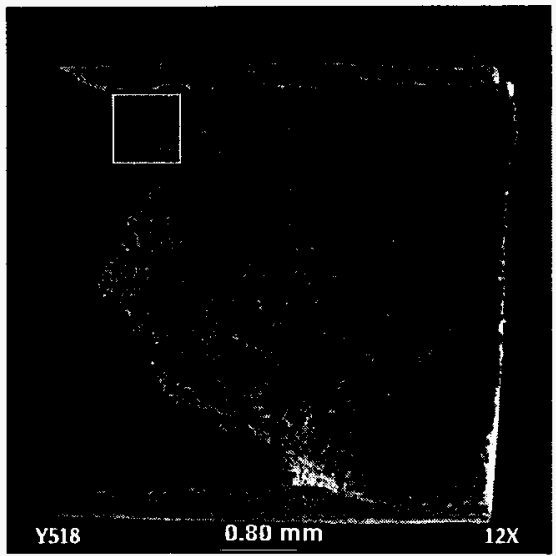

Figure A.14a. Fracture of Specimen from Solution 13

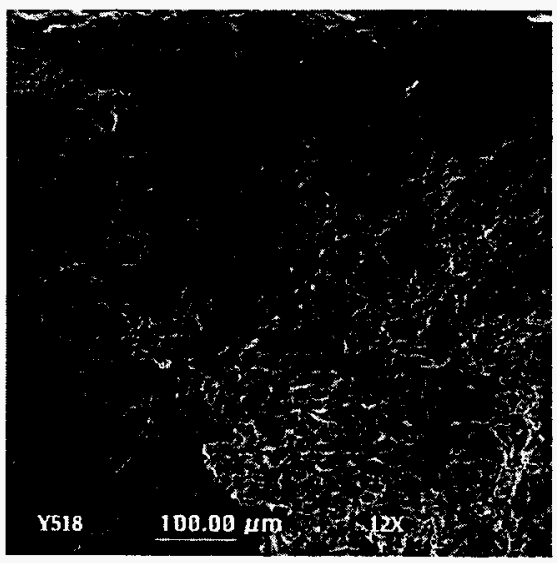

Figure A.14b. Higher Magnification of Fracture Surface

A.14 
WHC-SD-WM-TI-765, Rev 0

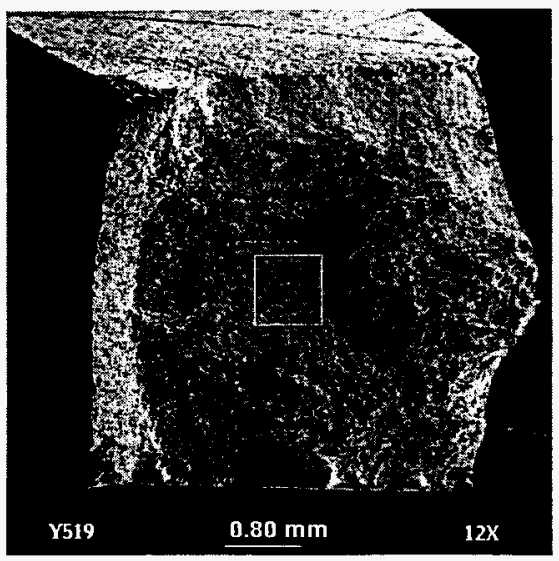

Figure A.15a. Fracture of Specimen from Solution 14

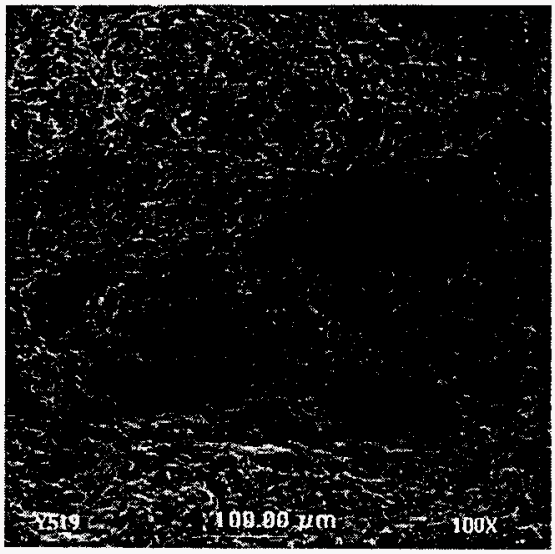

Figure A.15b. Higher Magnification of Fracture Surface 


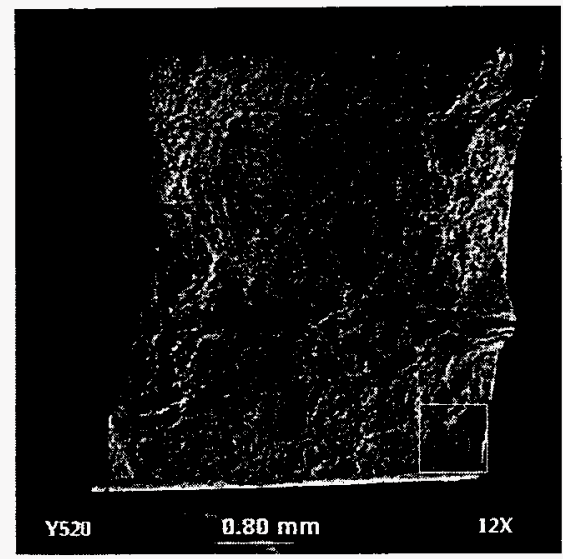

Figure A.16a. Fracture of Specimen from Solution 15

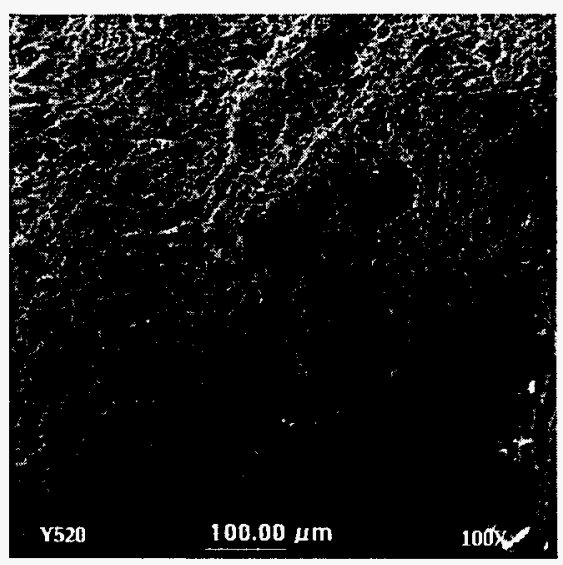

Figure A.16b. Higher Magnification of Fracture Surface A.16 
WHC-SD-WM-TI-765, Rev 0

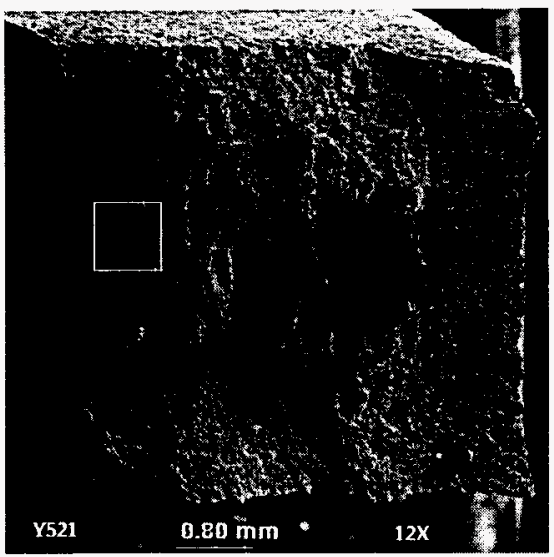

Figure A.17a. Fracture of Specimen from Solution 16

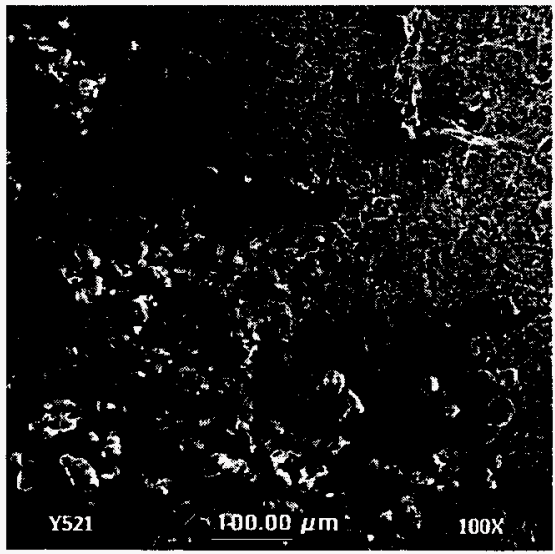

Figure A.17b. Higher Magnification of Fracture Surface 
WHC-SD-WM-TI-765, Rev 0

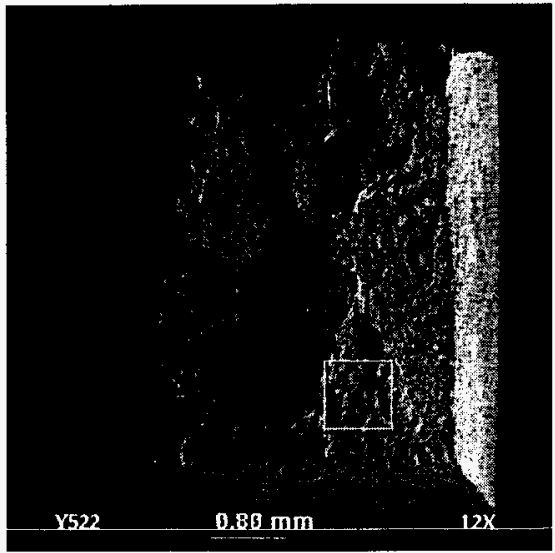

Figure A.18a. Fracture of Specimen from Solution 17

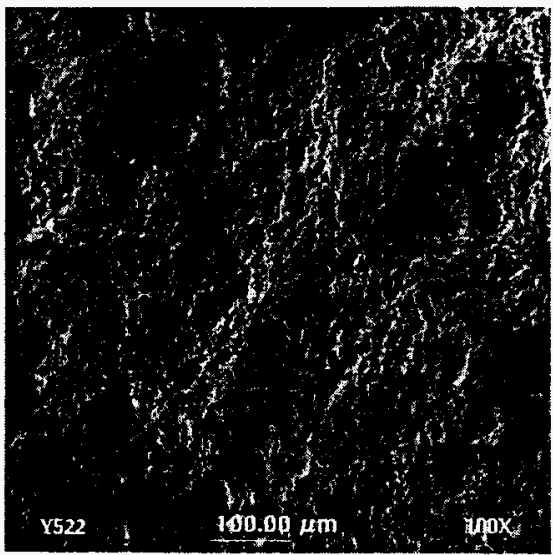

Figure A.18b. Higher Magnification of Fracture Surface 
WHC-SD-WM-TI-765, Rev 0

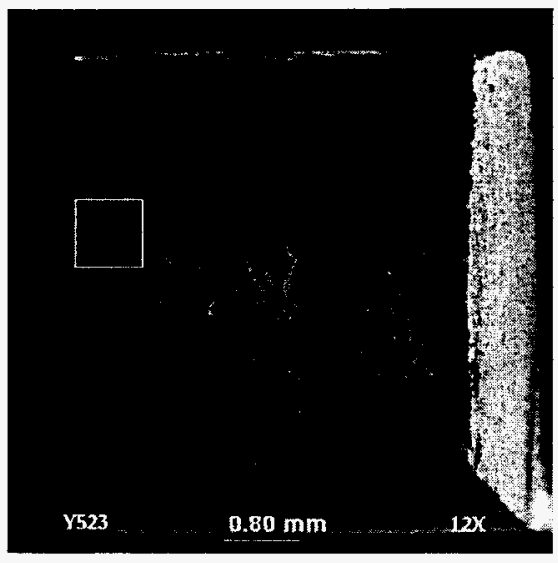

Figure A.19a. Fracture of Specimen from Solution 18

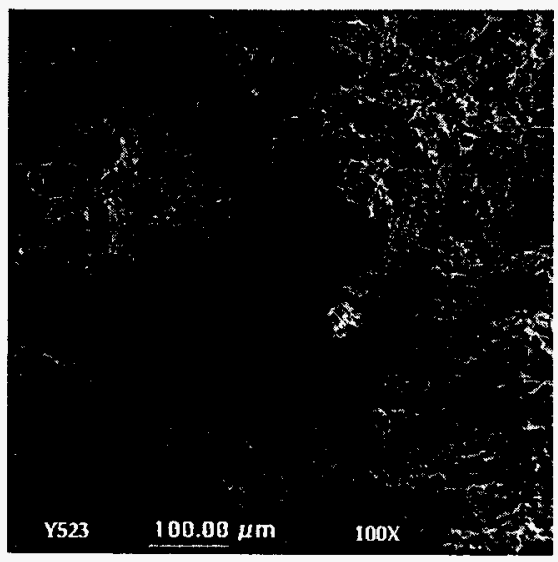

Figure A.19b. Higher Magnification of Fracture Surface 
WHC-SD-WM-TI-765, Rev 0

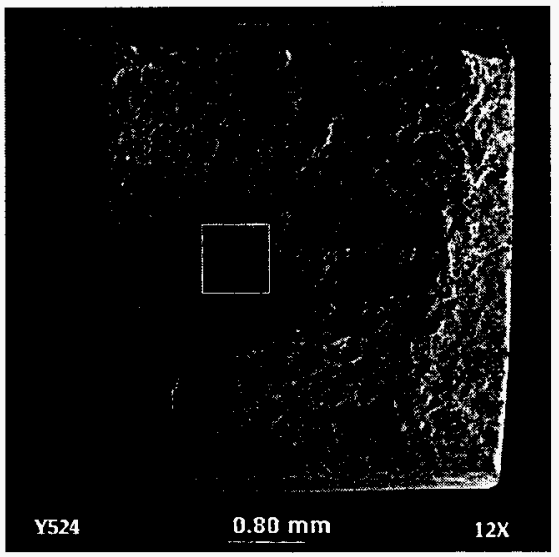

Figure A.20a. Fracture of Specimen from Solution 19

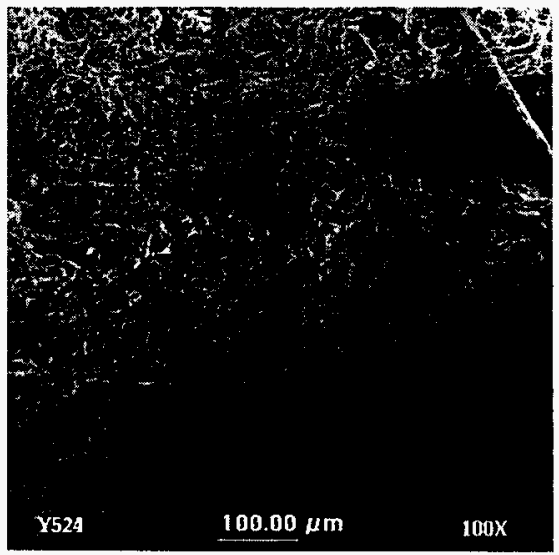

Figure A.20b. Higher Magnification of Fracture Surface 


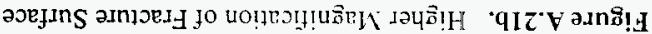

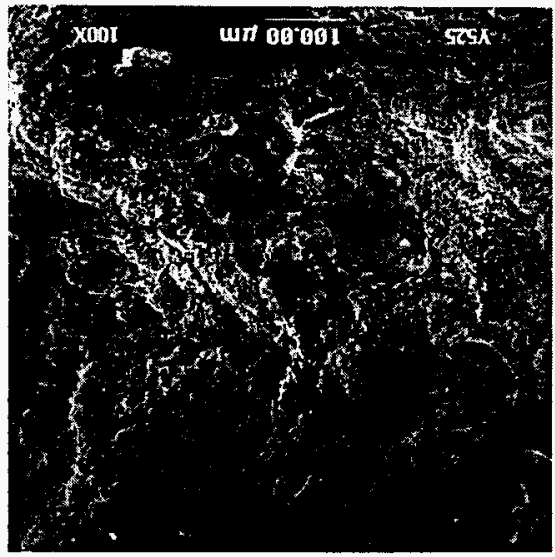

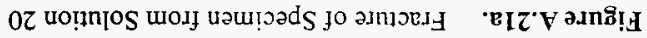

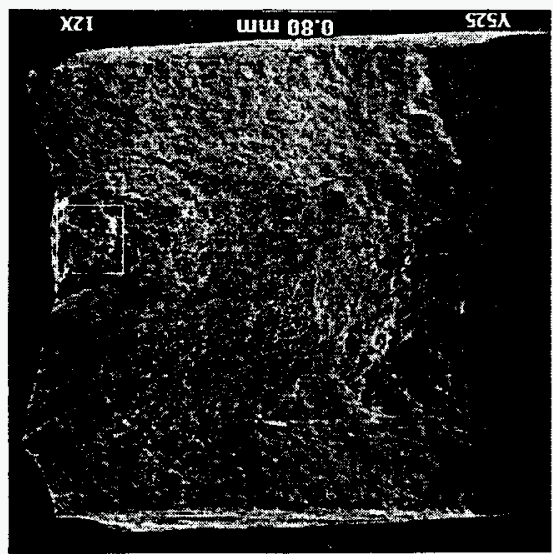


WHC-SD-WM-TI-765, Rev 0

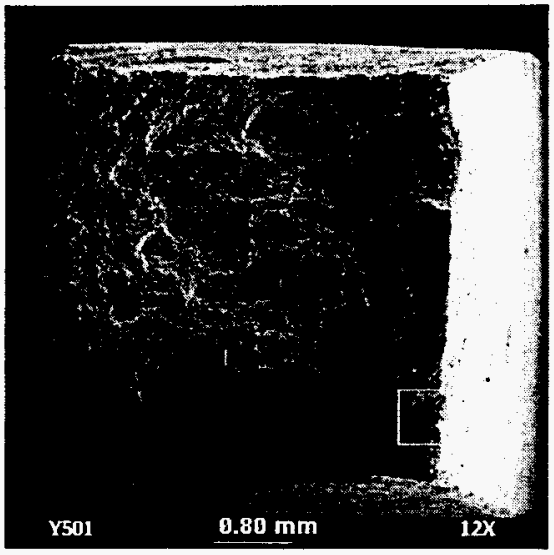

Figure A.22a. Fracture of Specimen from Solution 21

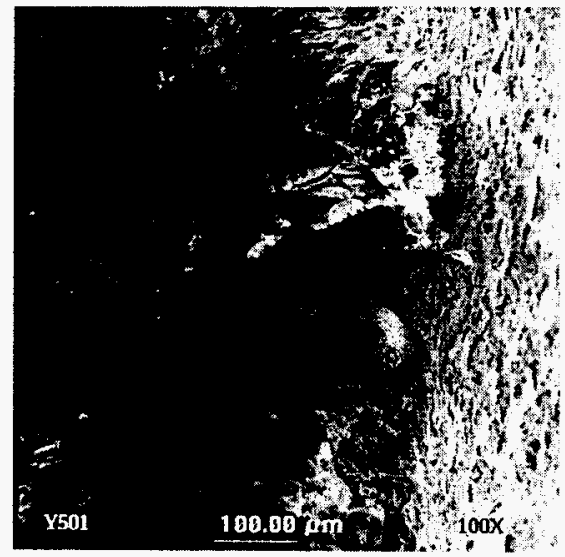

Figure A.22b. Higher Magnification of Fracture Surface 
WHC-SD-WM-TI-765, Rev 0

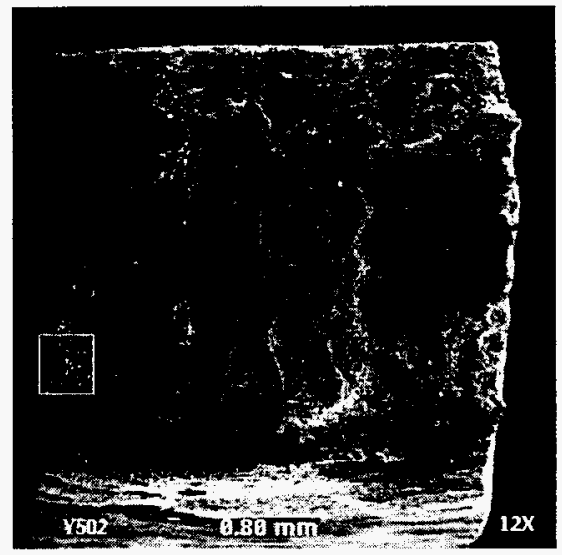

Figure A.23a. Fracture of Specimen from Solution 22

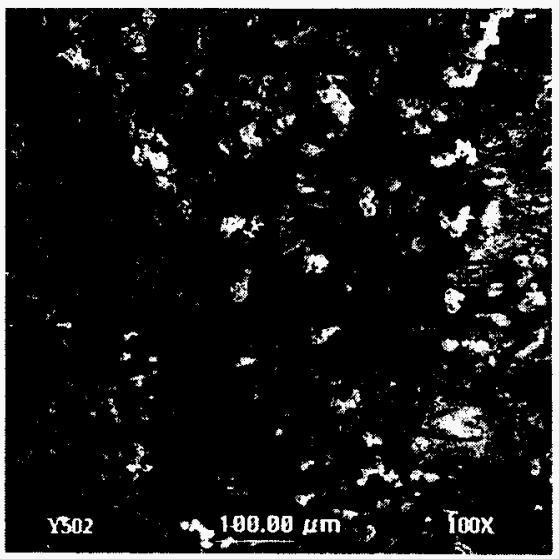

Figure A.23b. Higher Magnification of Fracture Surface 


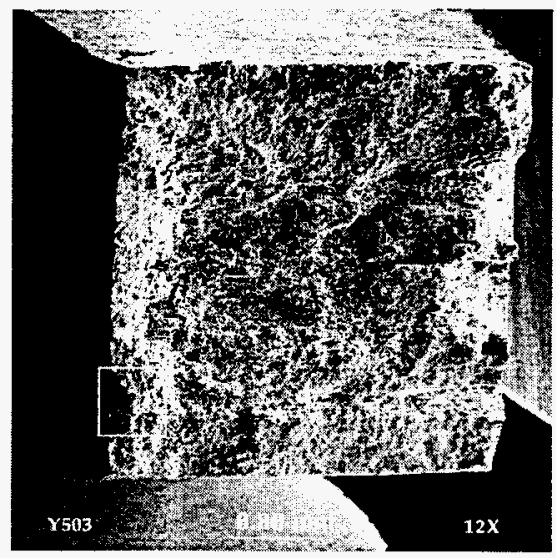

Figure A.24a. Fracture of Specimen from Solution 23

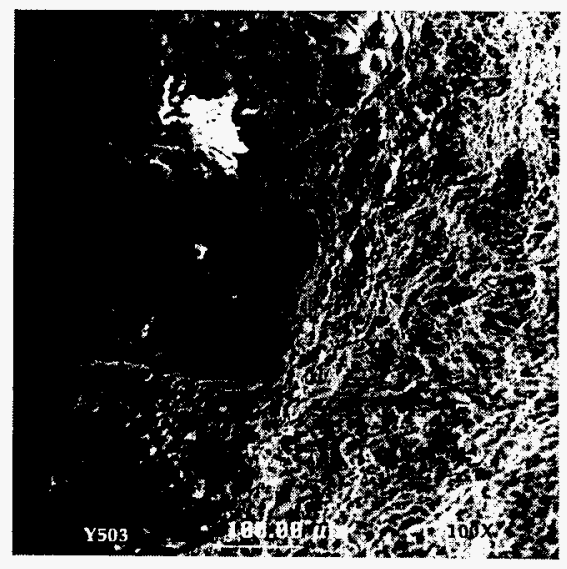

Figure A.24b. Higher Magnification of Fracture Surface 


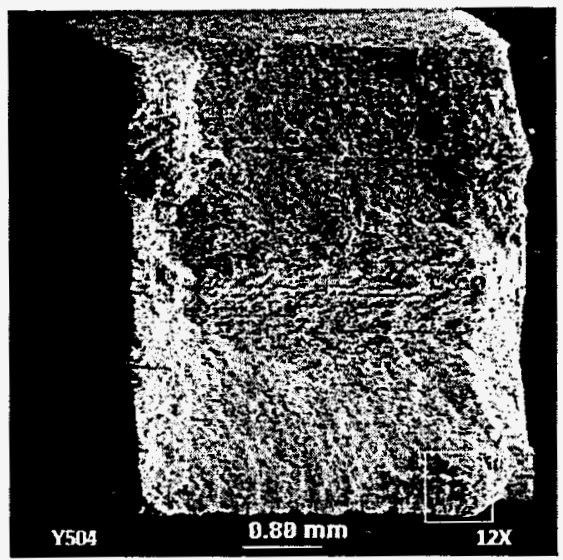

Figure A.25a. Fracture of Specimen from Solution 24

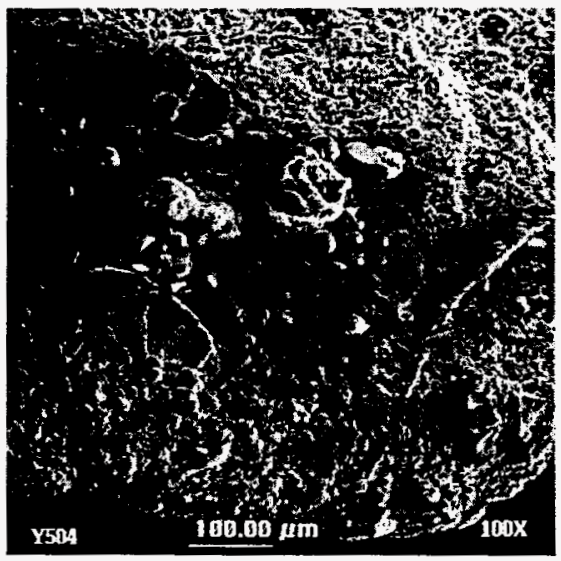

Figure A.25b. Higher Magnification of Fracture Surface 


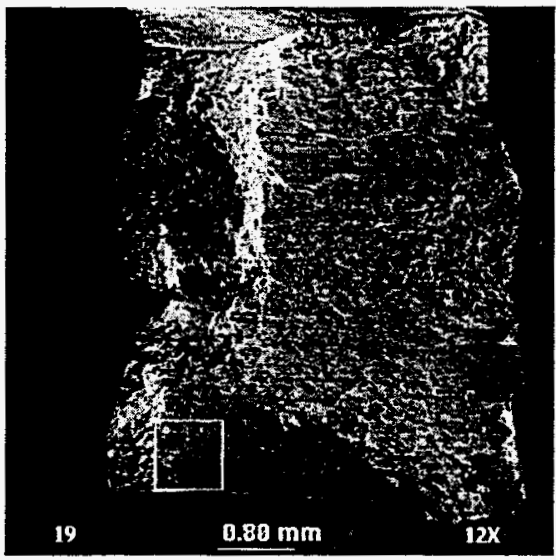

Figure A.26a. Fracture of FY94 Specimen from Solution 12

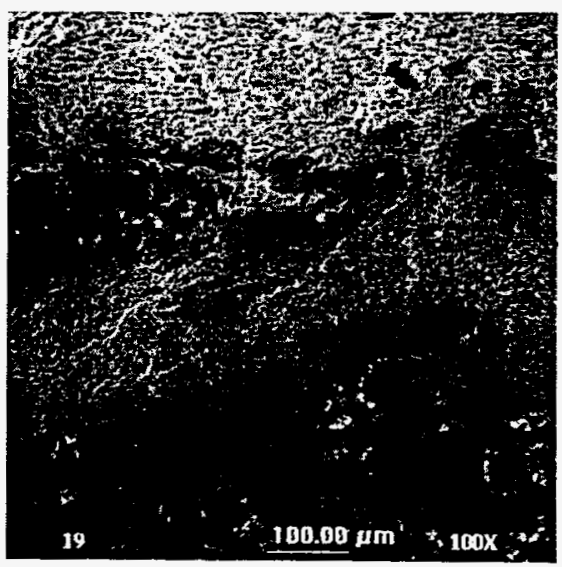

Figure A.26b. Higher Magnification of Fracture Surface 


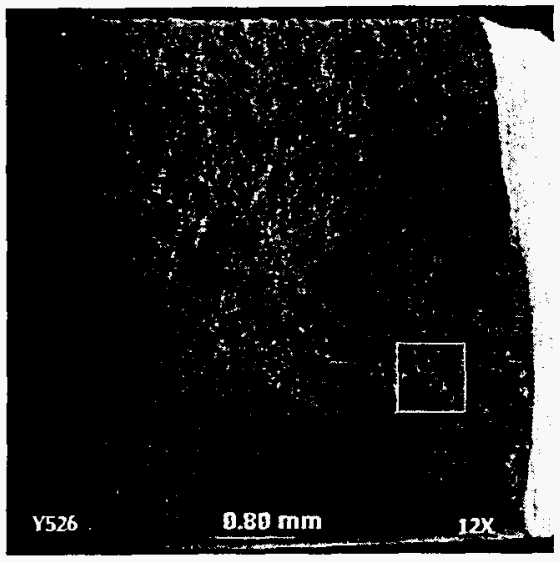

Figure A.27a. Fracture of Specimen from Solution 12, Slower Strain Rate

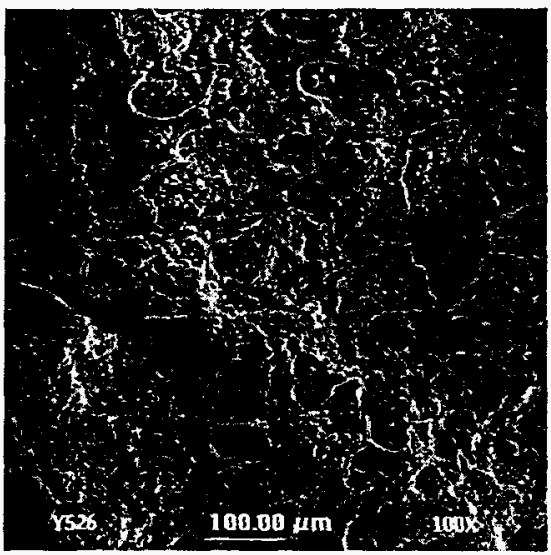

Figure A.27b. Higher Magnification of Fracture Surface 
HHC-SD-HM-TI-765, Rev 0

APPENDIX B: POTENTIODYNAMIC SCANS

B- $\mathbf{i}$ 
WHC-SD-WM-TI-765, Rev 0

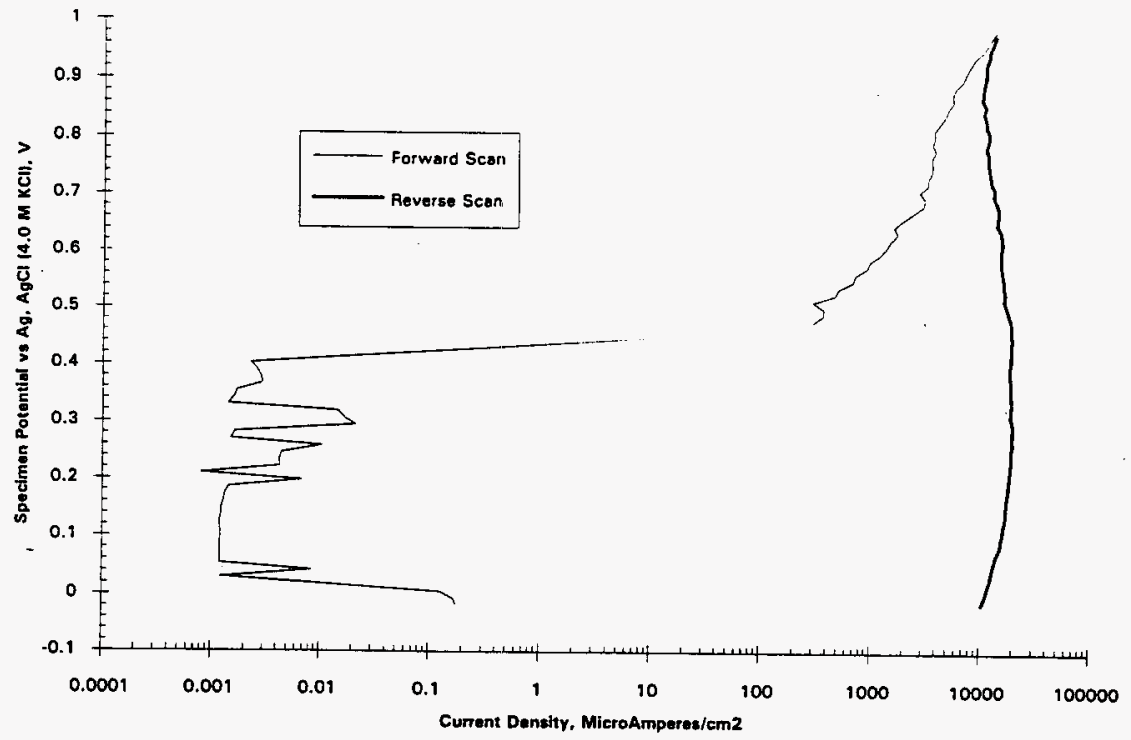

Figure B.1. Potentiodynamic Scan in Solution 1

B. 1 
WHC-SD-WM-TI-765, Rev 0

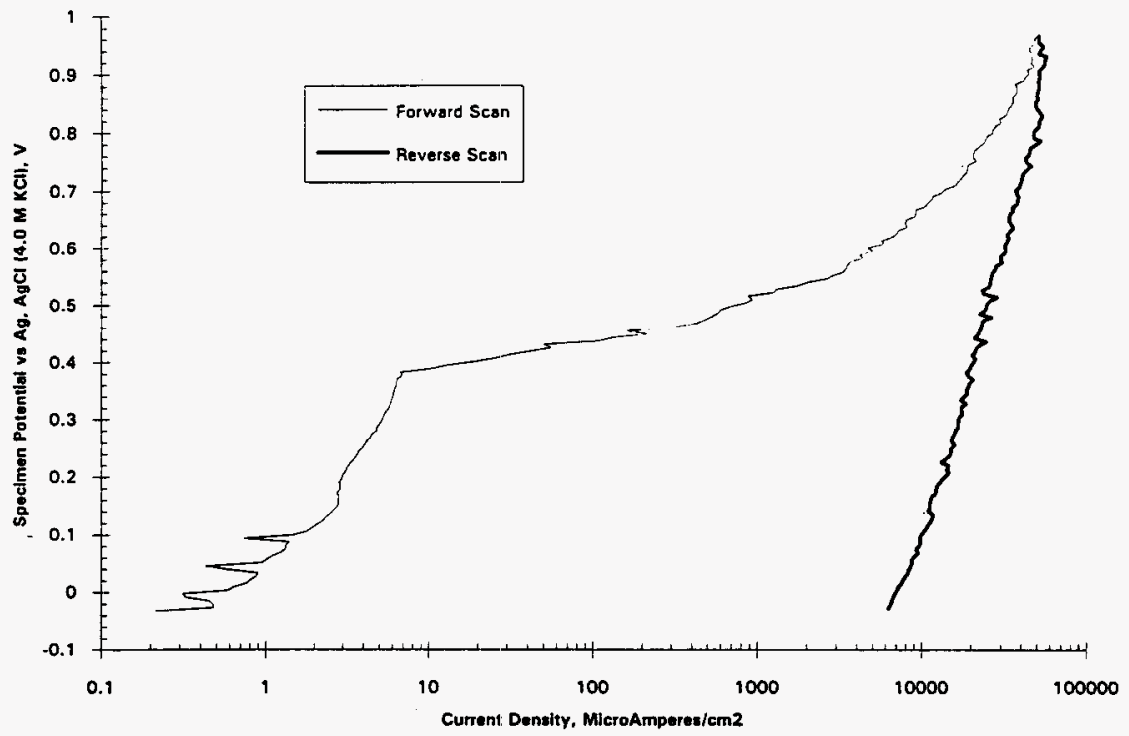

Figure B.2. Potentiodynamic Scan in Solution 2

B. 2 


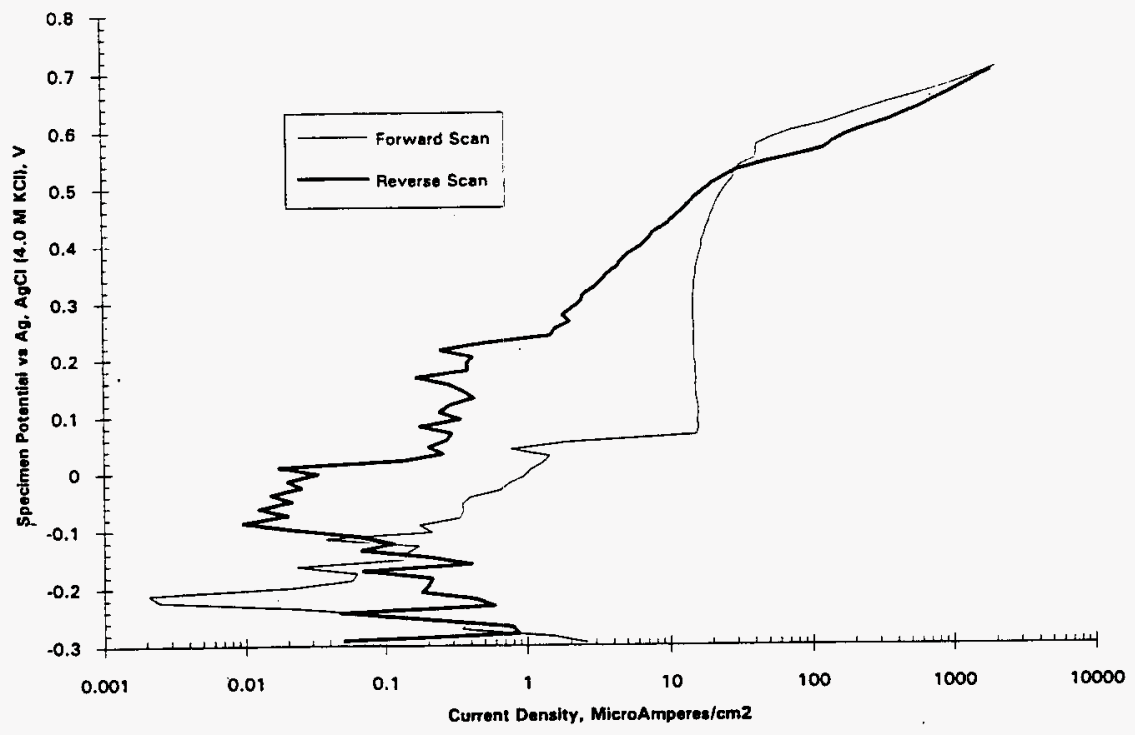

Figure B.3. Potentiodynamic Scan in Solution 3

B. 3 


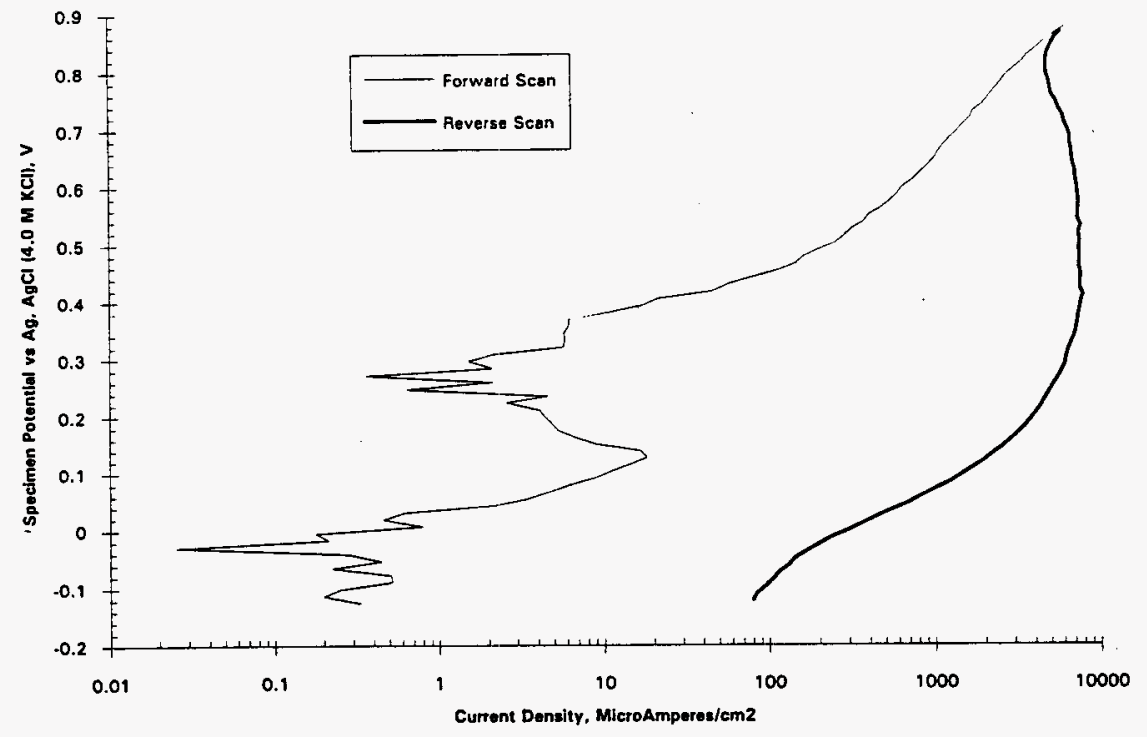

Figure B.4. Potentiodynamic Scan in Solution 4 
WHC-SD-WM-TI-765, Rev 0

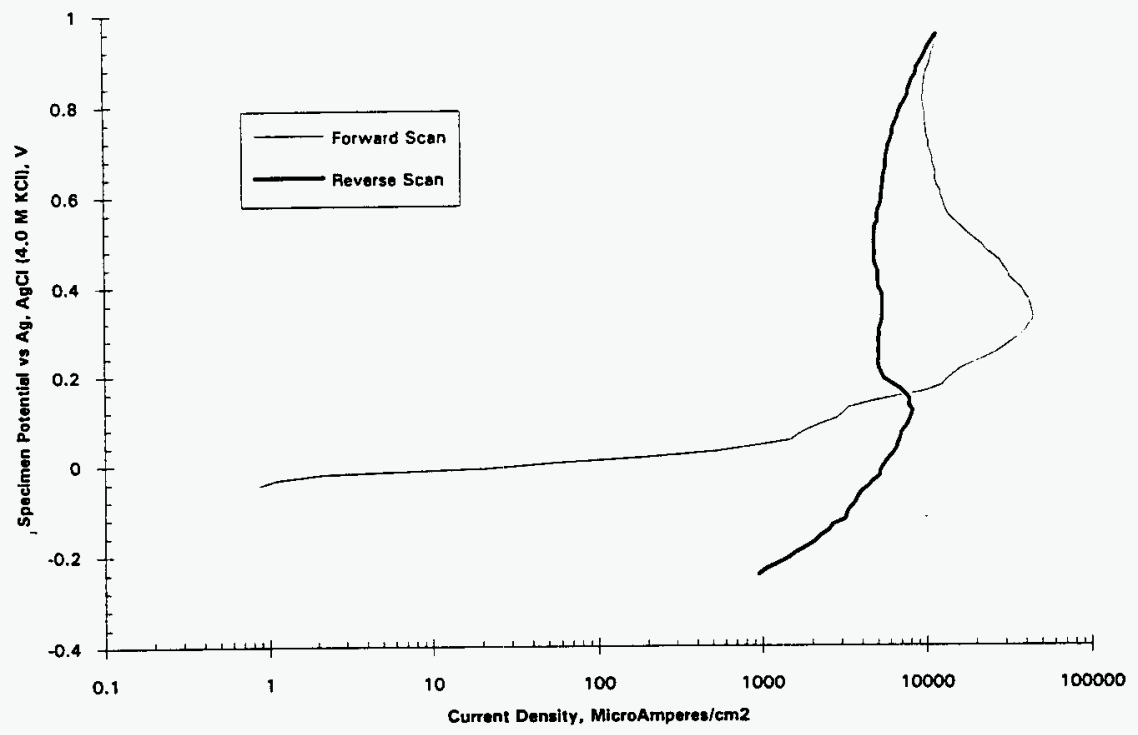

Figure B.5. Potentiodynamic Scan in Solution 5

B.5 
WHC-SD-WM-TI-765, Rev 0

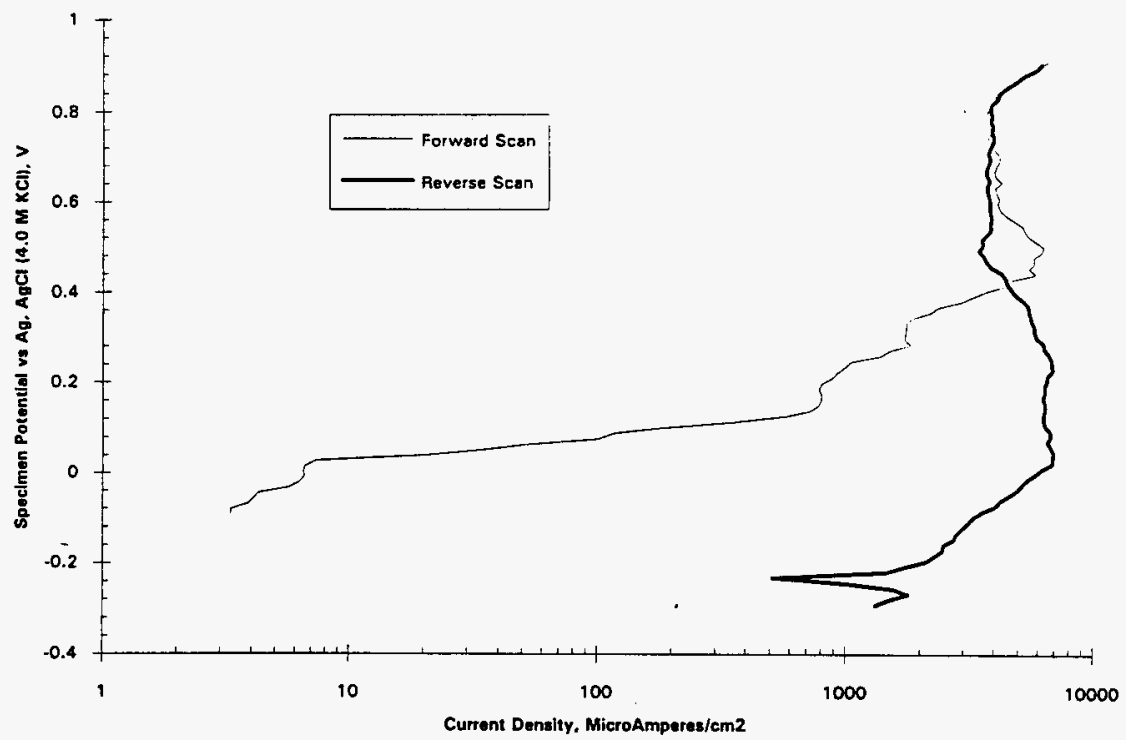

Figure B.6. Potentiodynamic Scan in Solution 6

B. 6 


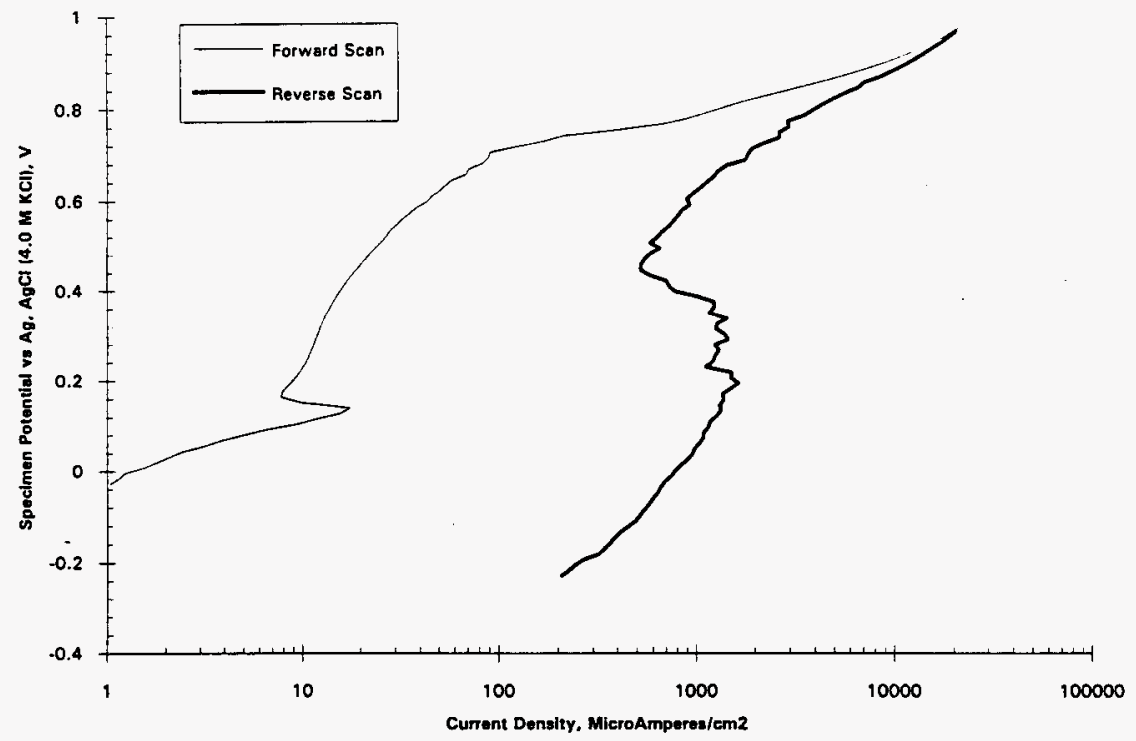

Figure B.7. Potentiodynamic Scan in Solution 7

B. 7 


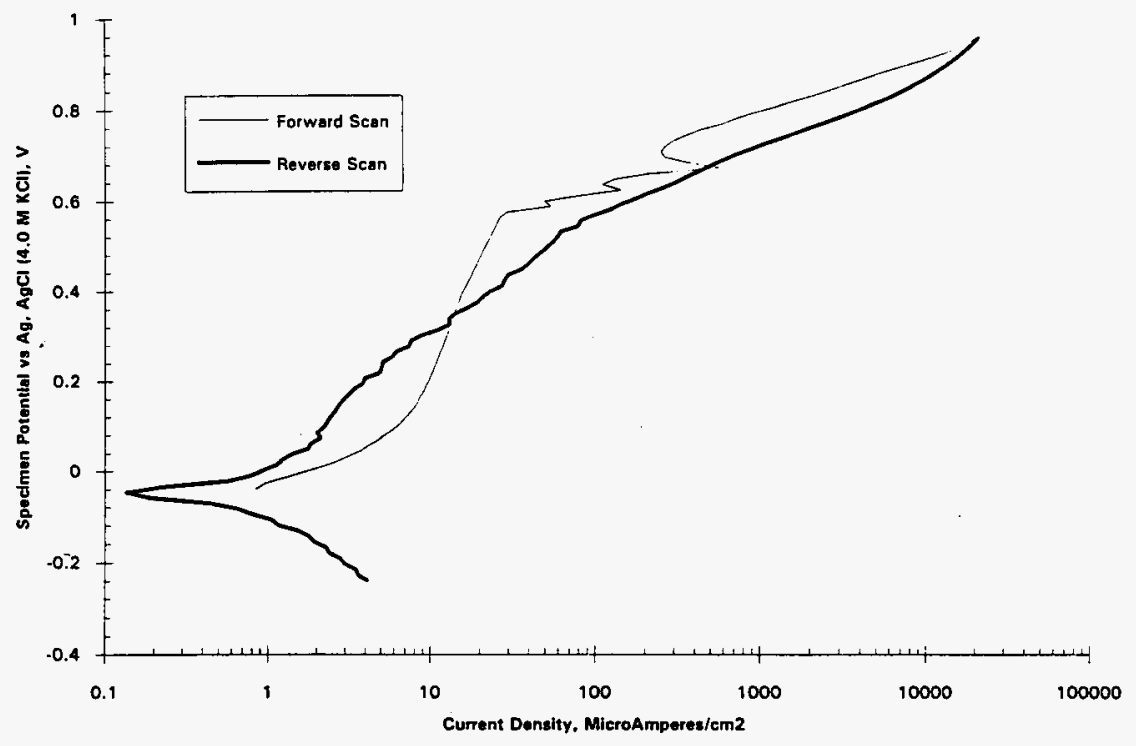

Figure B.8. Potentiodynamic Scan in Solution 8 


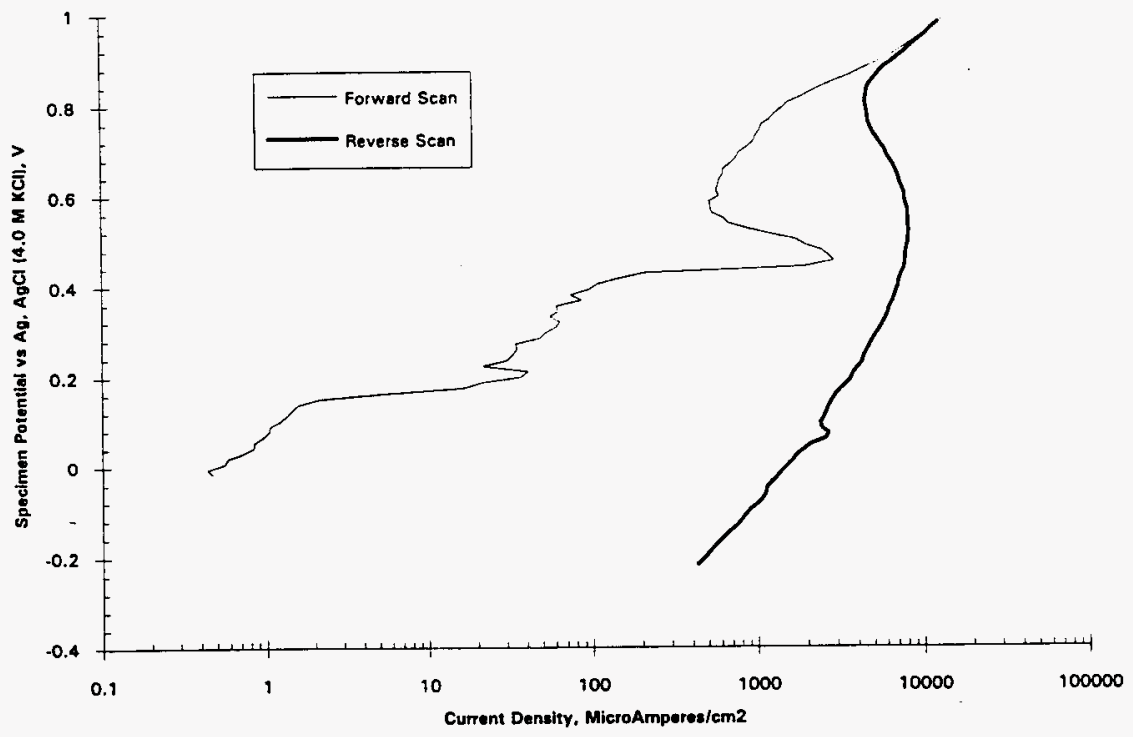

Figure B.9. Potentiodynamic Scan in Solution 9

B. 9 
WHC-SD-WM-TI-765, Rev 0

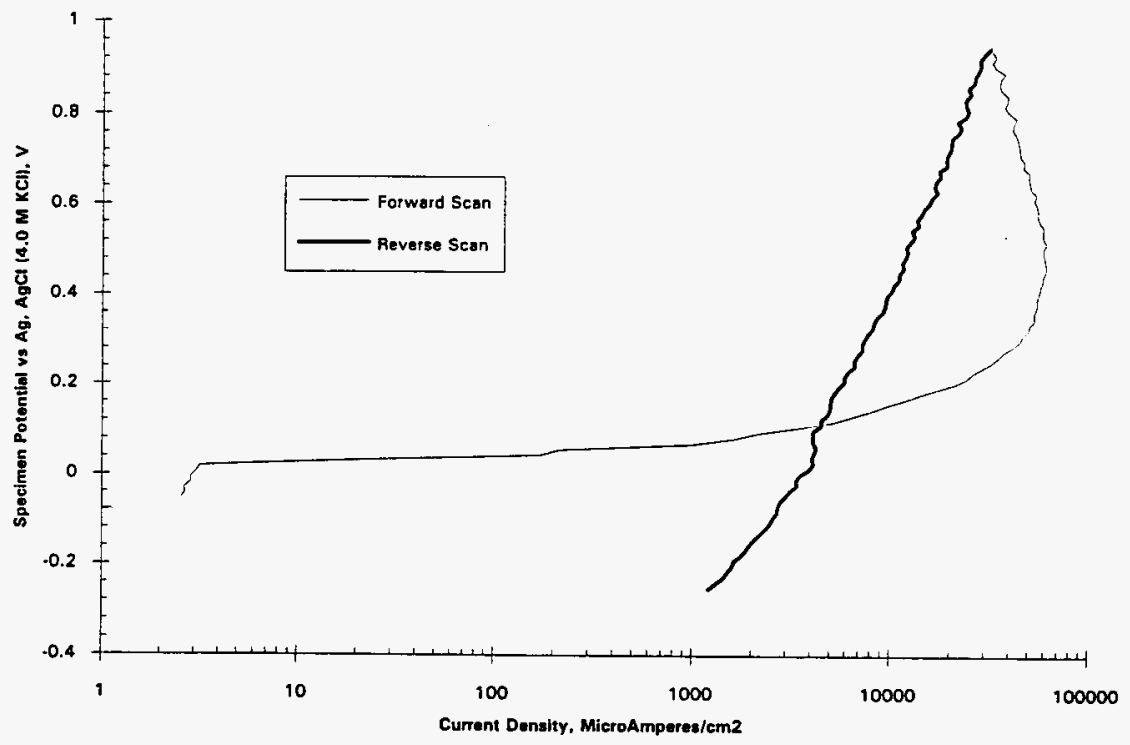

Figure B.10. Potentiodynamic Scan in Solution 10

B. 10 


\section{WHC-SD-WM-TI-765, Rev 0}

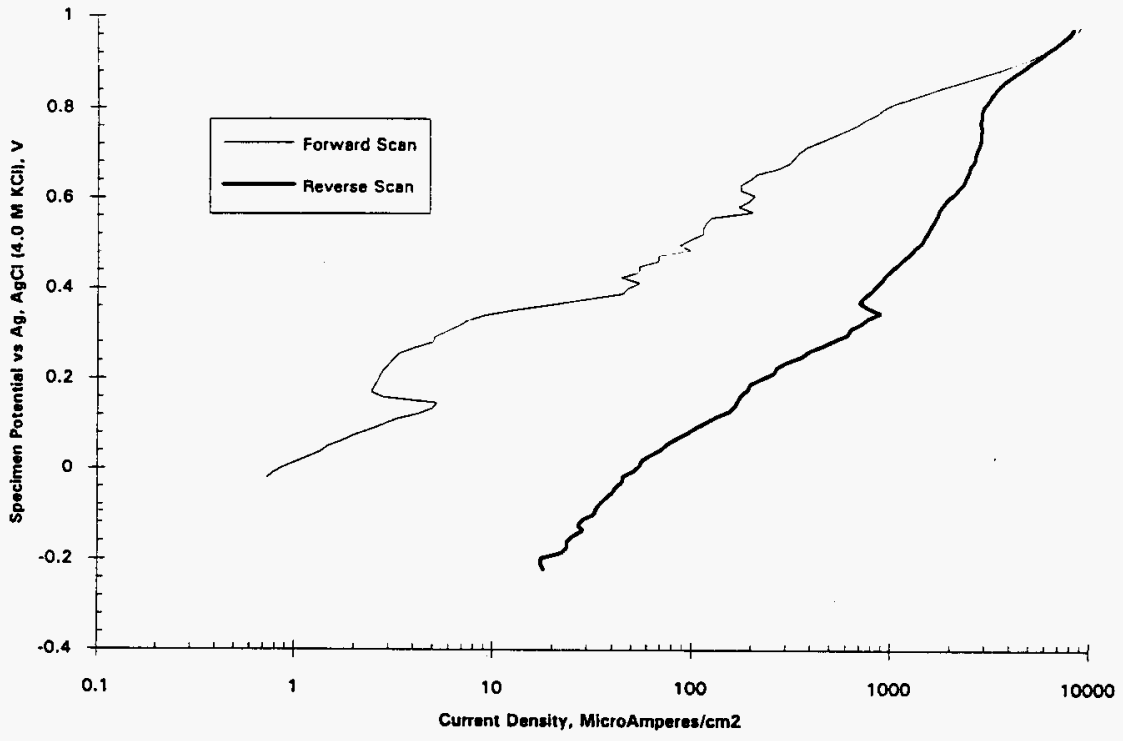

Figure B.11. Potentiodynamic Scan in Solution 11 
WHC-SD-WH-TI-765, Rev 0

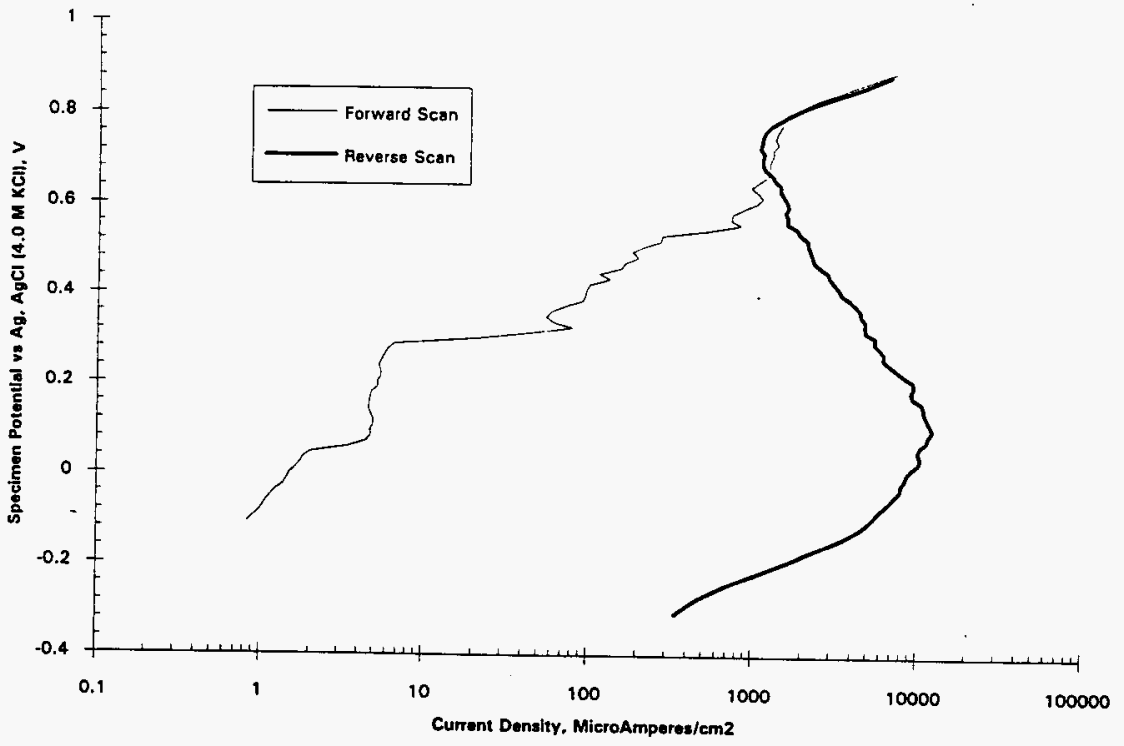

Figure B.12. Potentiodynamic Scan in Solution 12

B. 12 


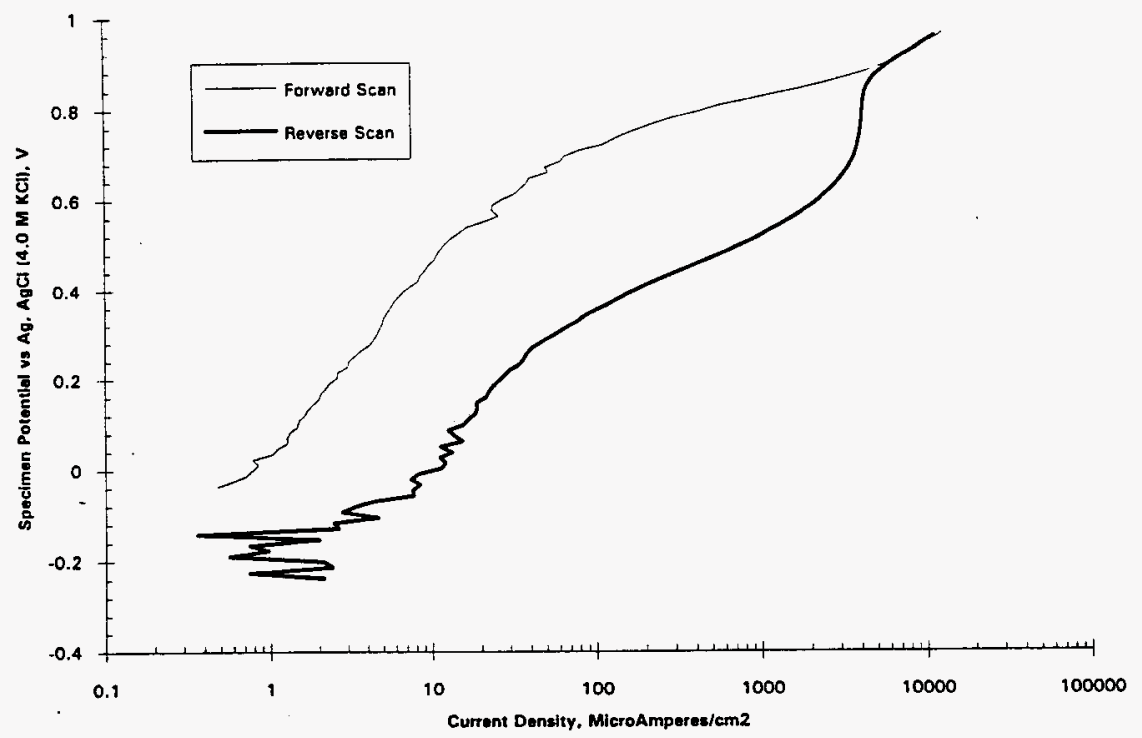

Figure B.13. Potentiodynamic Scan in Solution 13

B. 13 


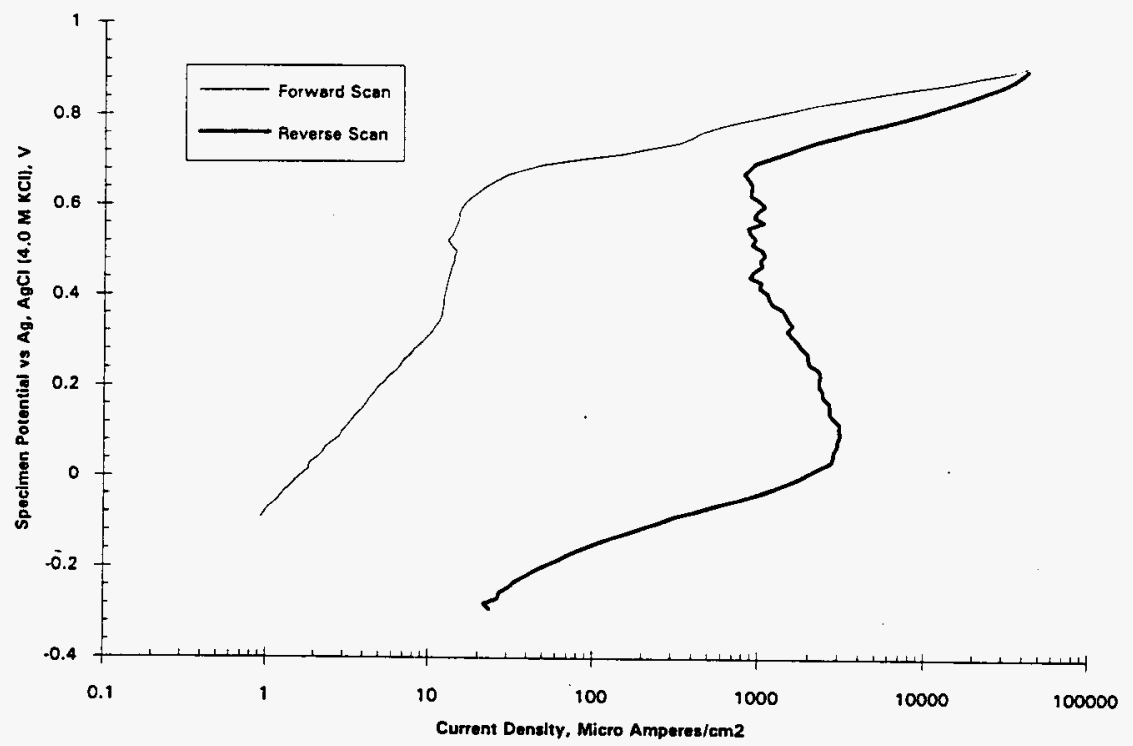

Figure B.14. Potentiodynamic Scan in Solution 14

B. 14 


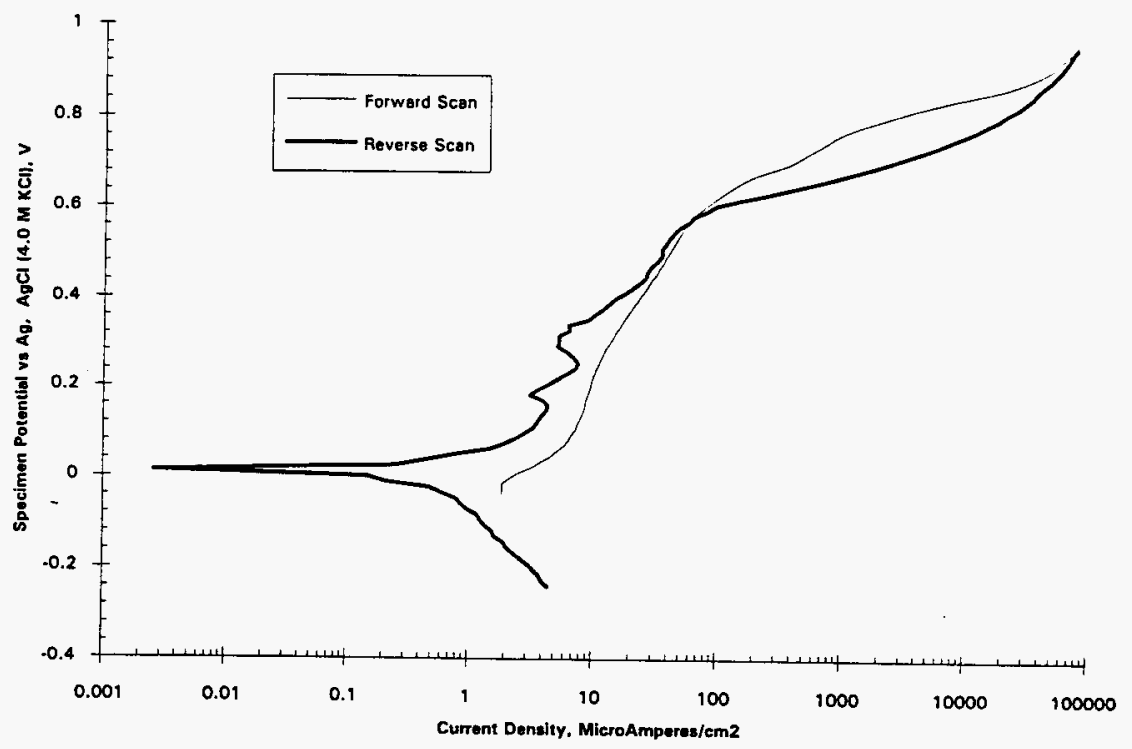

Figure B.15. Potentiodynamic Scan in Solution 15

\section{B. 15}




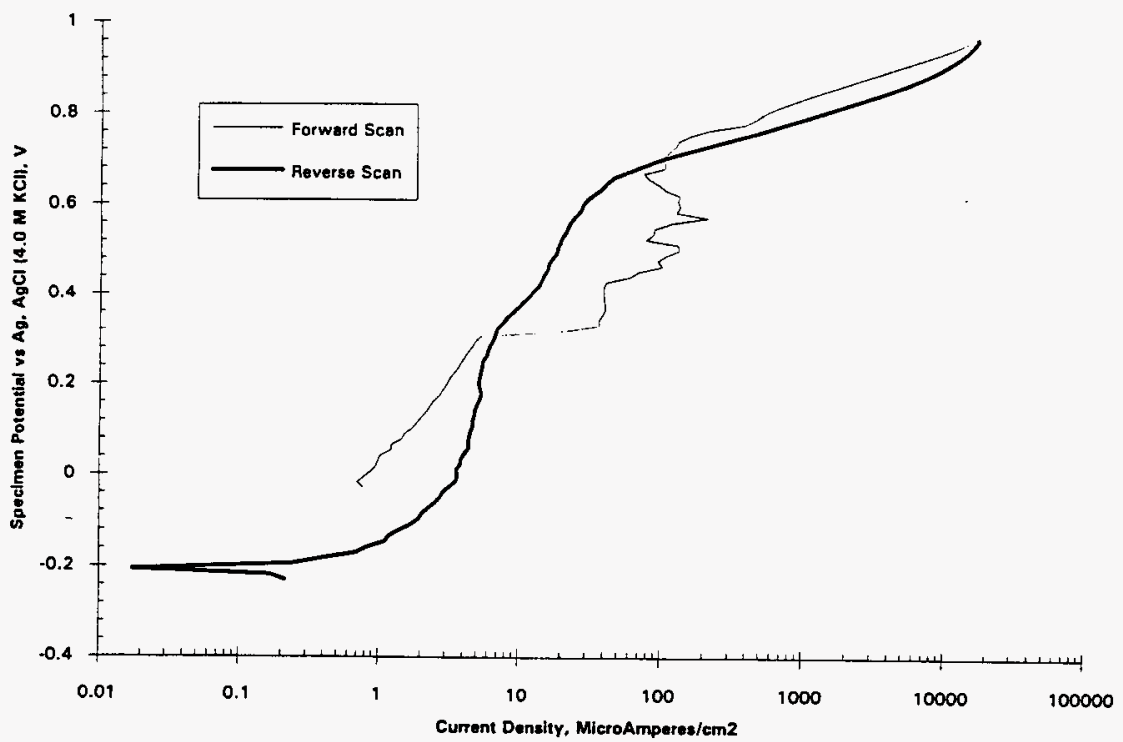

Figure B.16. Potentiodynamic Scan in Solution 16

B. 16 
WHC-SD-WM-TI-765, Rev 0

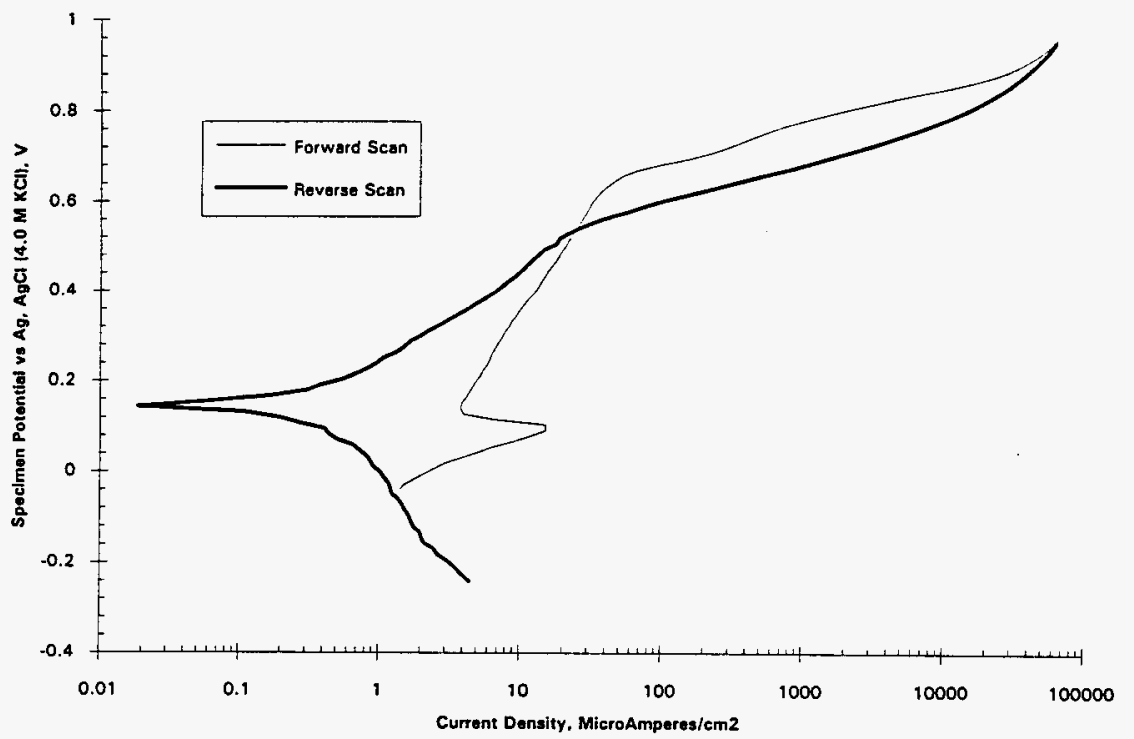

Figure B.17. Potentiodynamic Scan in Solution 17

B. 17 


\section{WHC-SD-WM-TI-765, Rev 0}

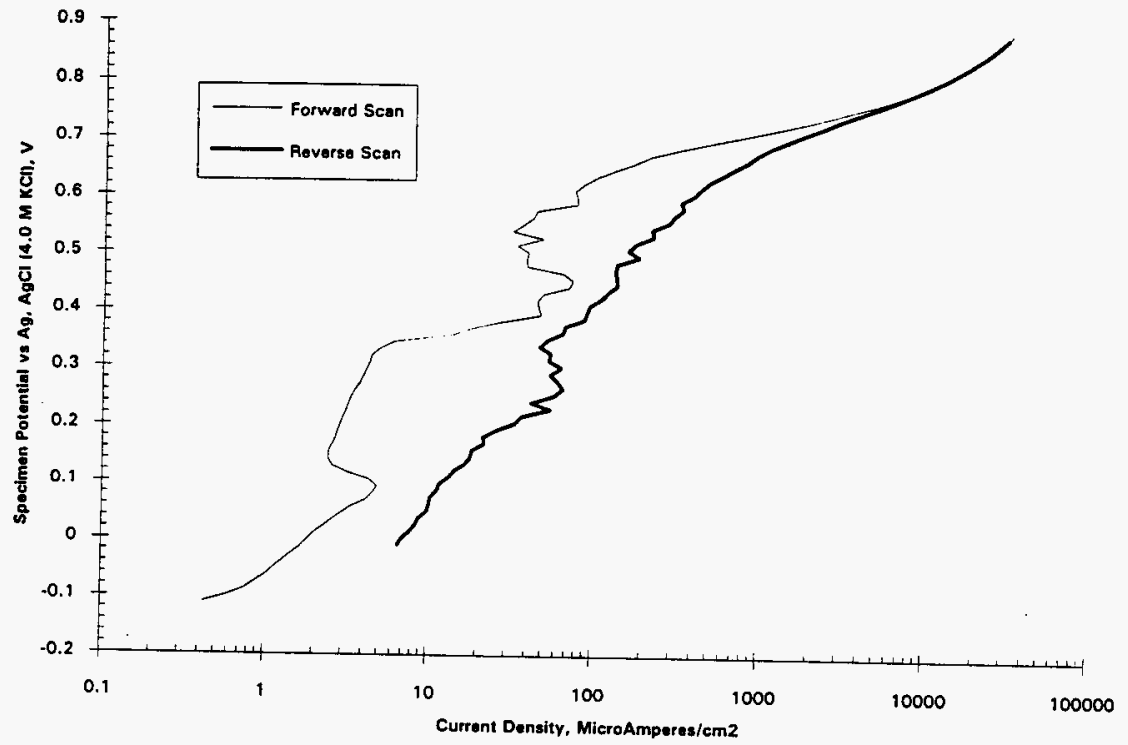

Figure B.18. Potentiodynamic Scan in Solution 18

B. 18 
WHC-SD-WM-TI-765, Rev 0

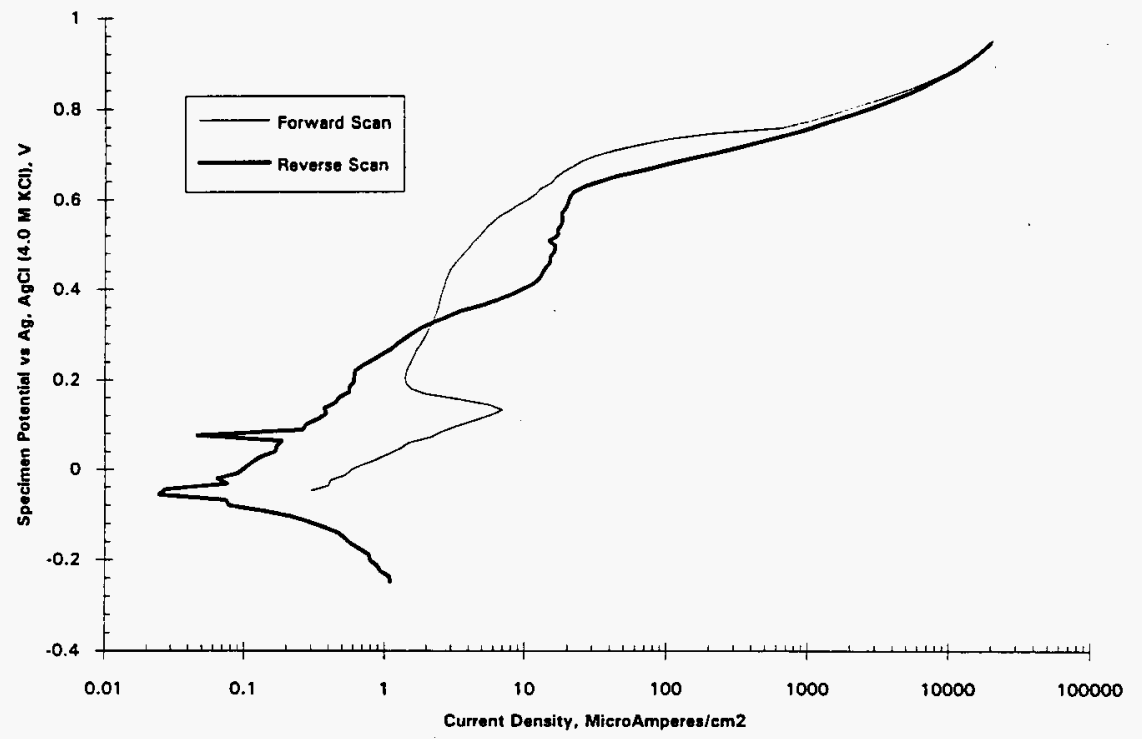

Figure B.19. Potentiodynamic Scan in Solution 19

\section{B. 19}


WHC-SD-WM-TI-765, Rev 0

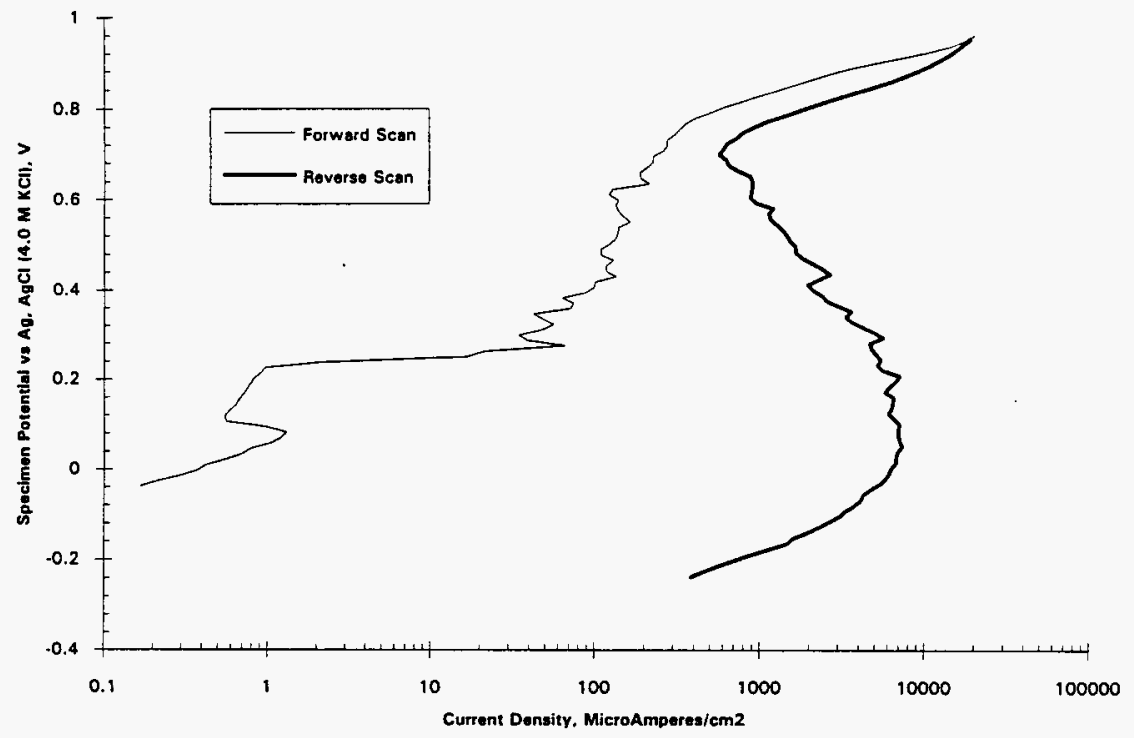

Figure B.20. Potentiodynamic Scan in Solution 20

B.20 
WHC-SD-WM-TI-765, Rev 0

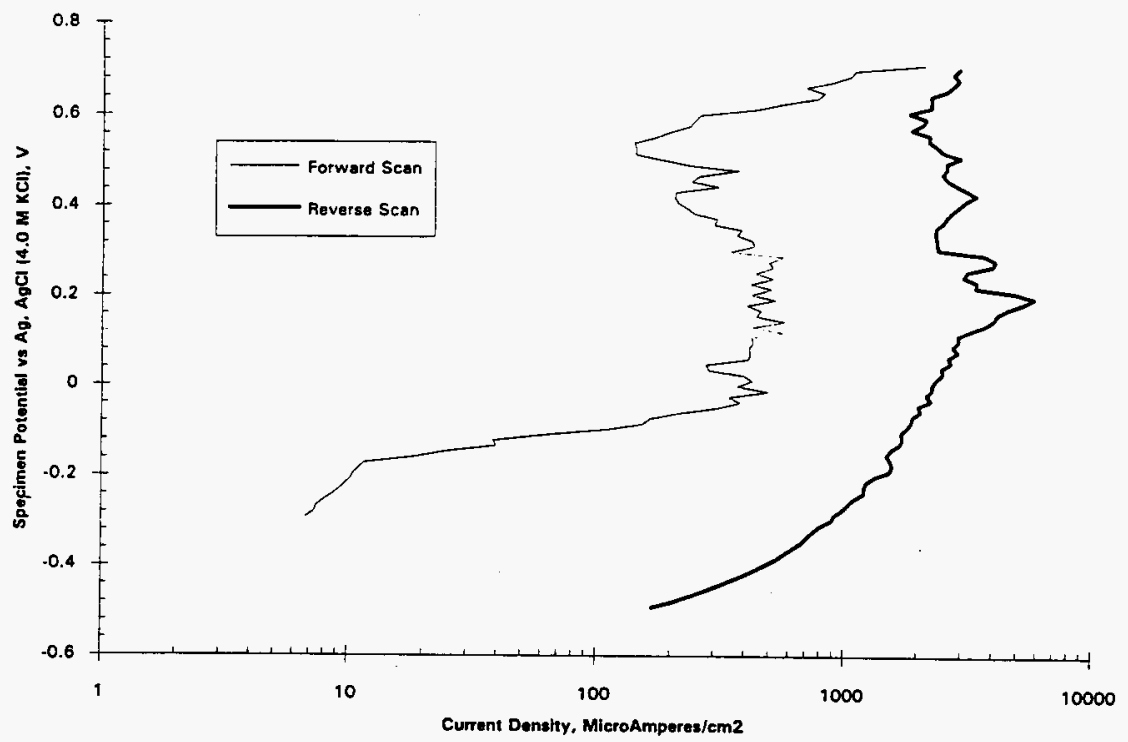

Figure B.21. Potentiodynamic Scan in Solution 21 


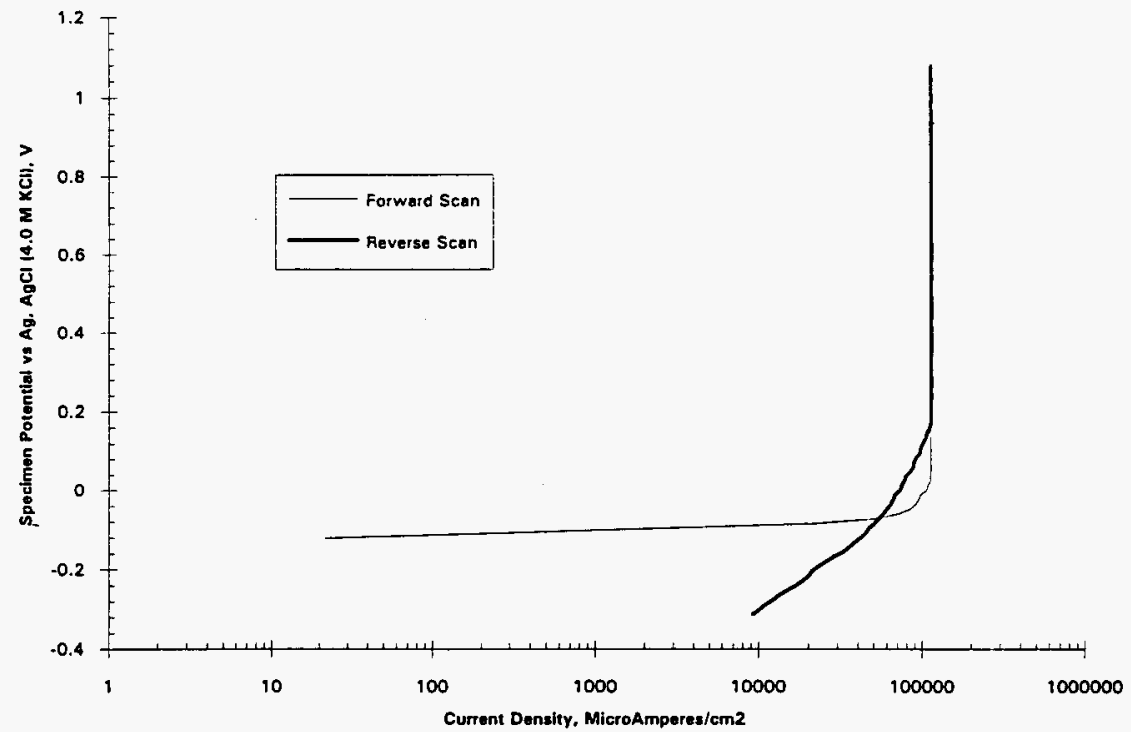

Figure B.22. Potentiodynamic Scan in Solution 22 
WHC-SD-WM-TI-765, Rev 0

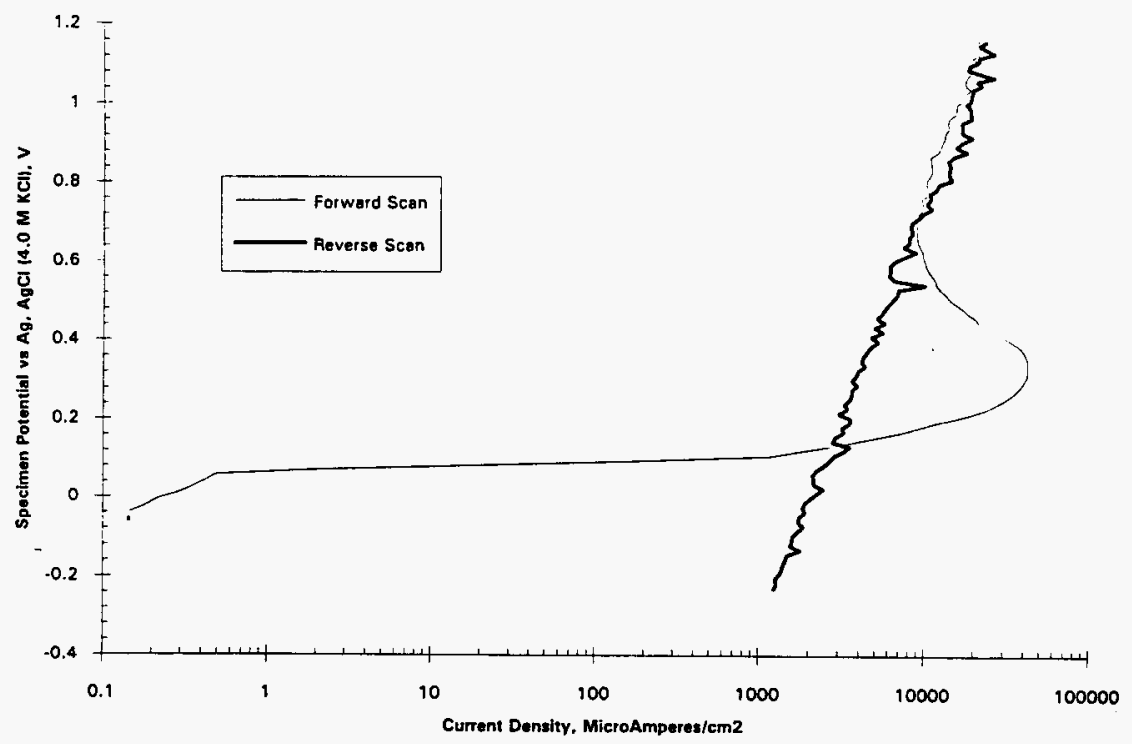

Figure B.23. Potentiodynamic Scan in Solution 23

B. 23 
WHC-SD-WM-TI-765, Rev 0

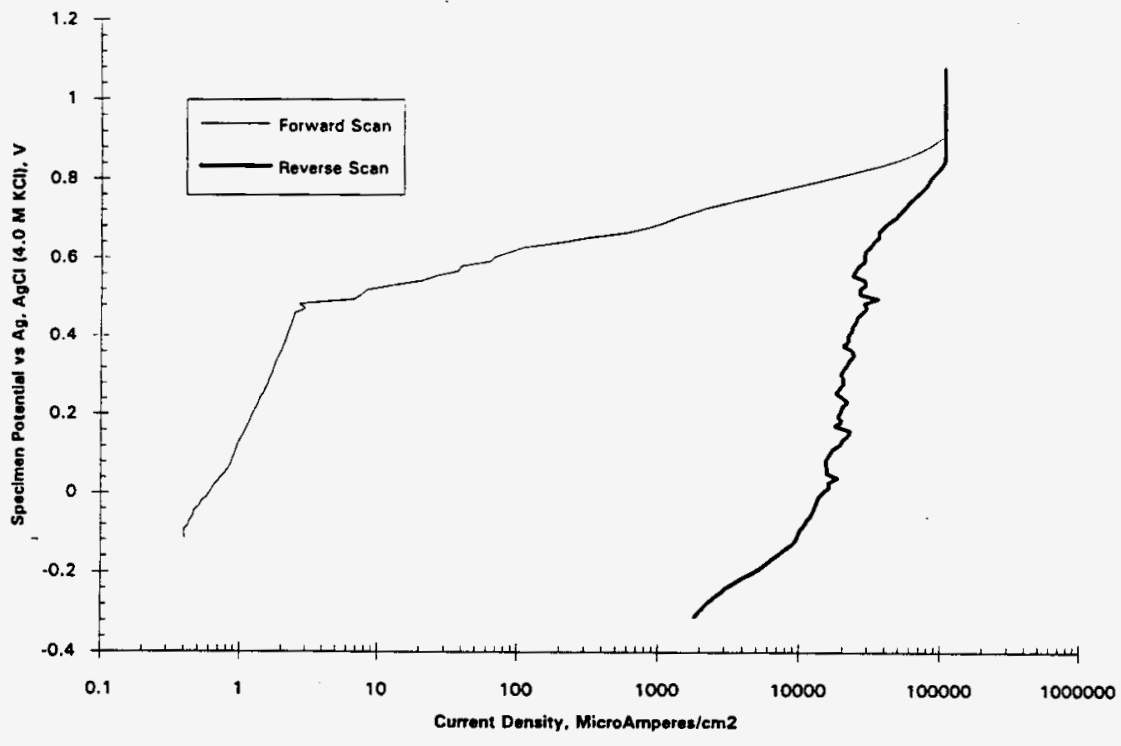

Figure B.24. Potentiodynamic Scan in Solution 24

B. 24 
WHC-SD-HM-TI-765, Rev 0

APPENDIX C: PHOTOGRAPHS OF REPRESENTATIVE SPECIMENS PRIOR TO CLEANING 
WHC-SD-WM-TI-765, Rev 0

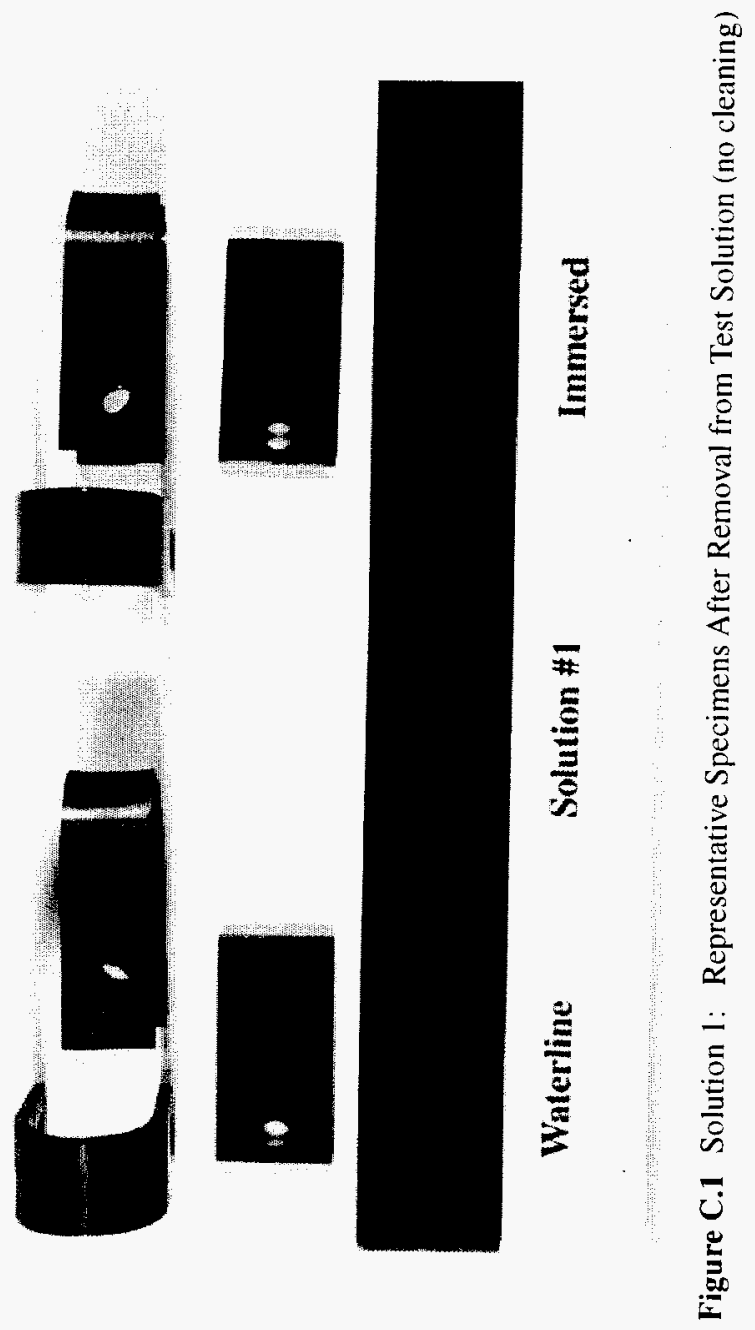

C. 1 
WHC-SD-WM-TI-765, Rev 0

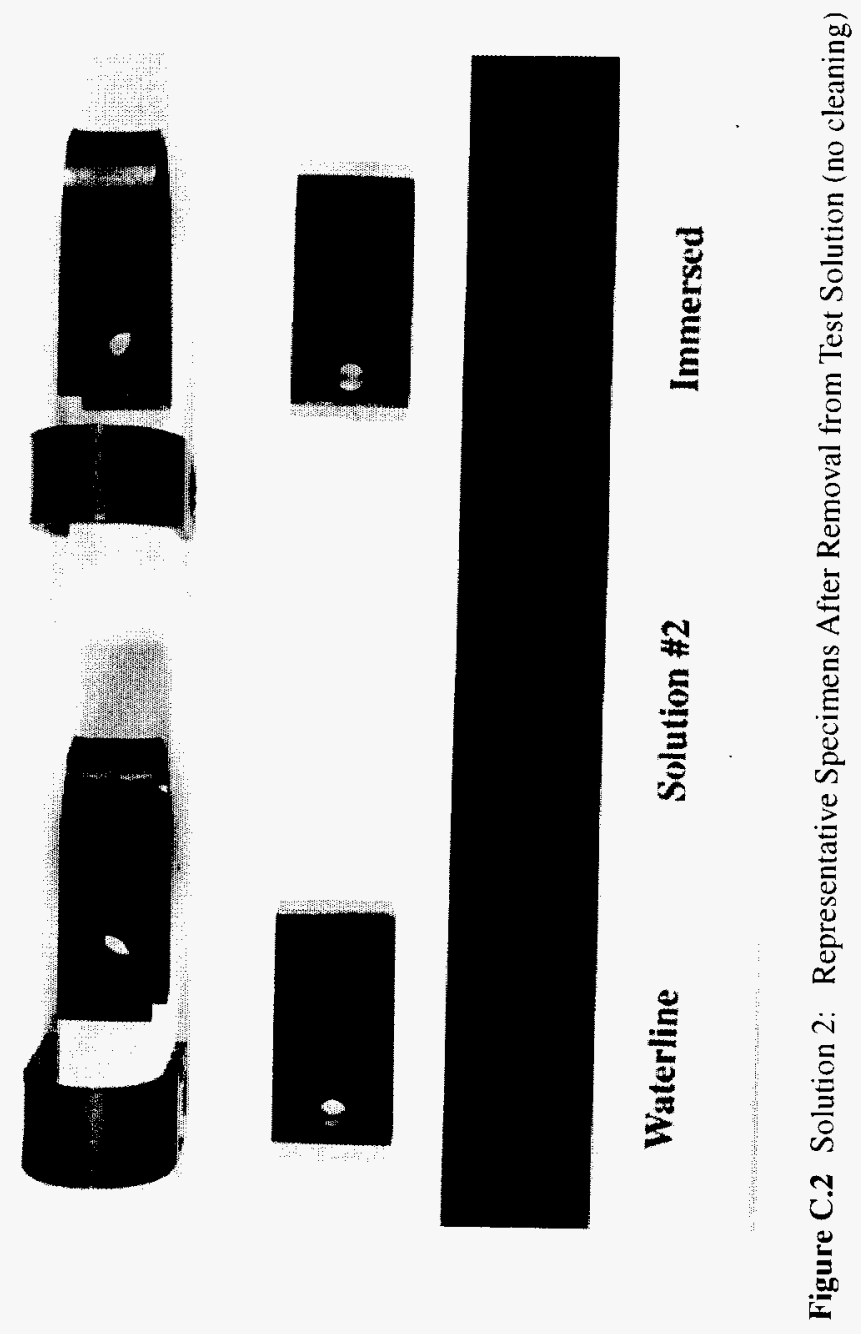

C.2 
WHC-SD-WM-TI-765, Rev 0
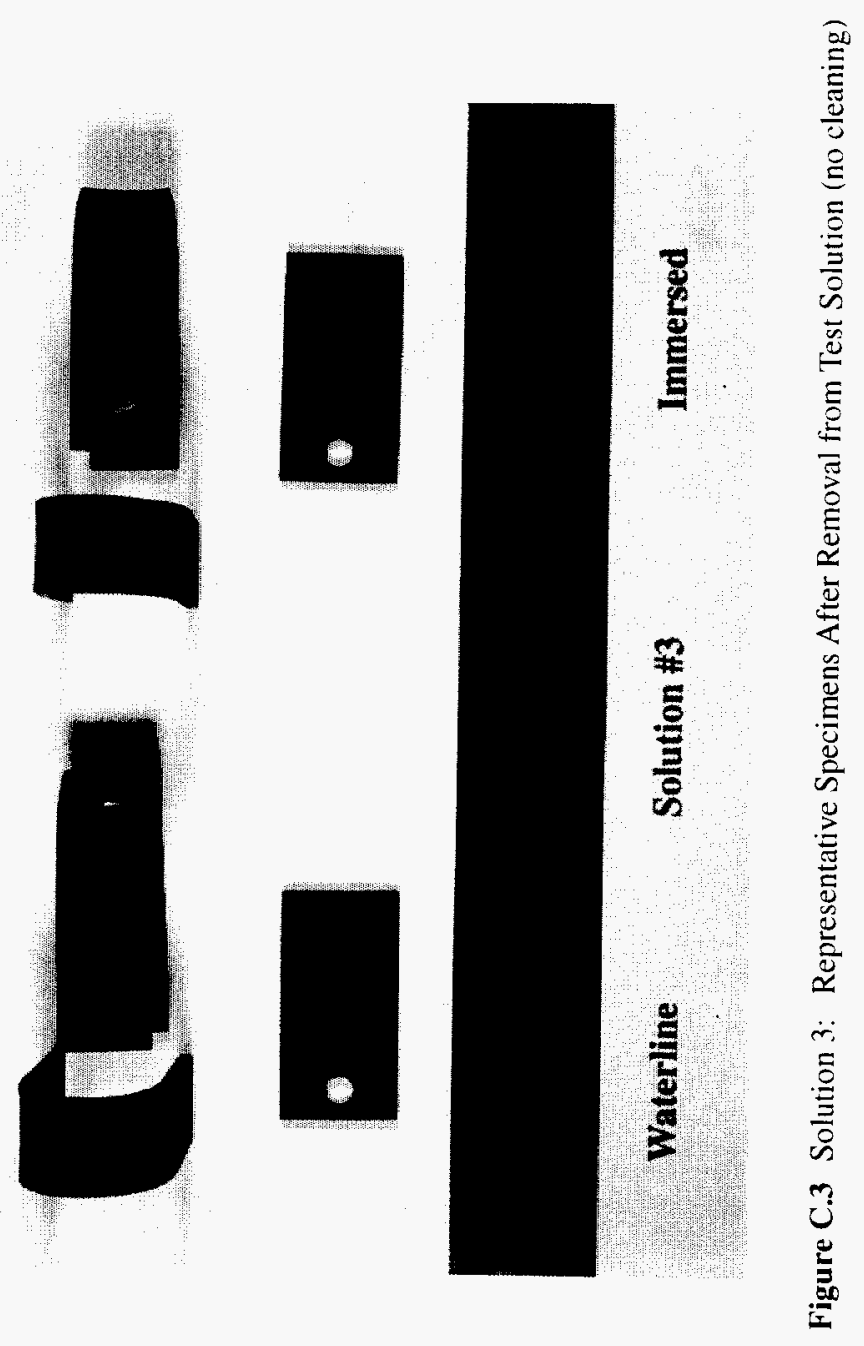

C. 3 
WHC-SD-WM-TI-765, Rev 0
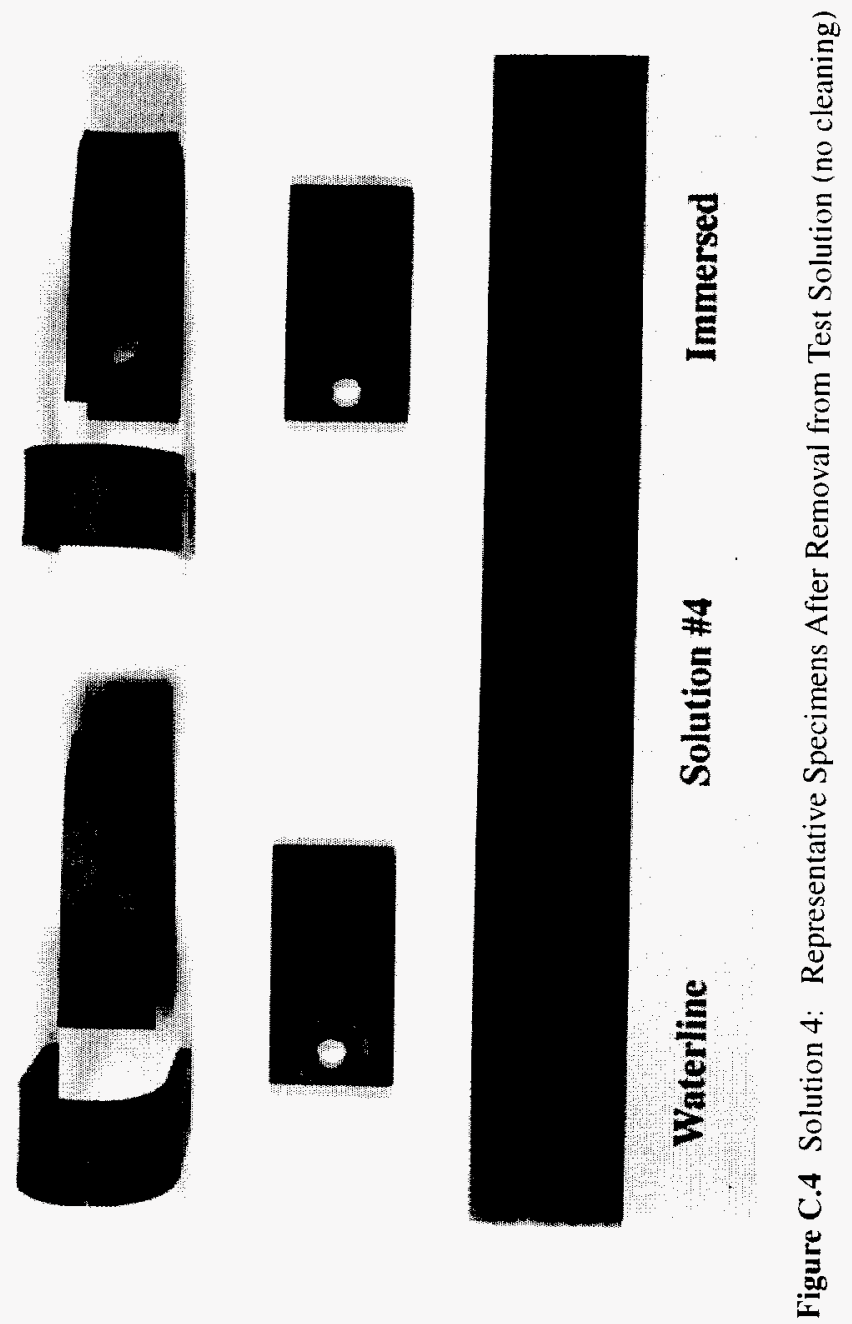

C. 4 

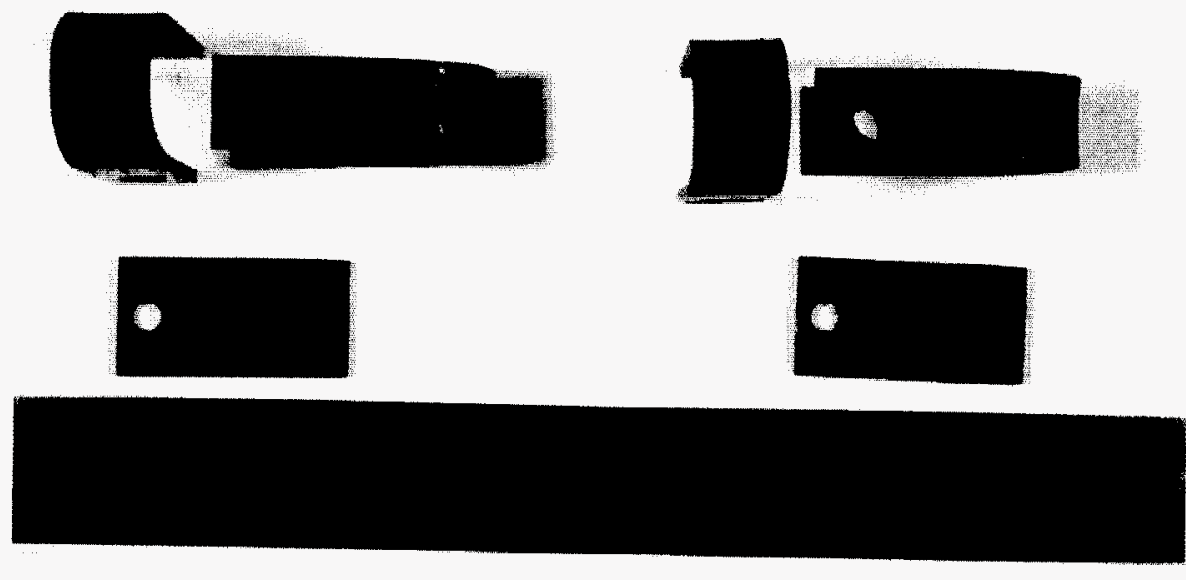

Waterline

Solution \#5

Immersed

Figure C.5 Solution 5: Representative Specimens After Removal from Test Solution (no cleaning) 

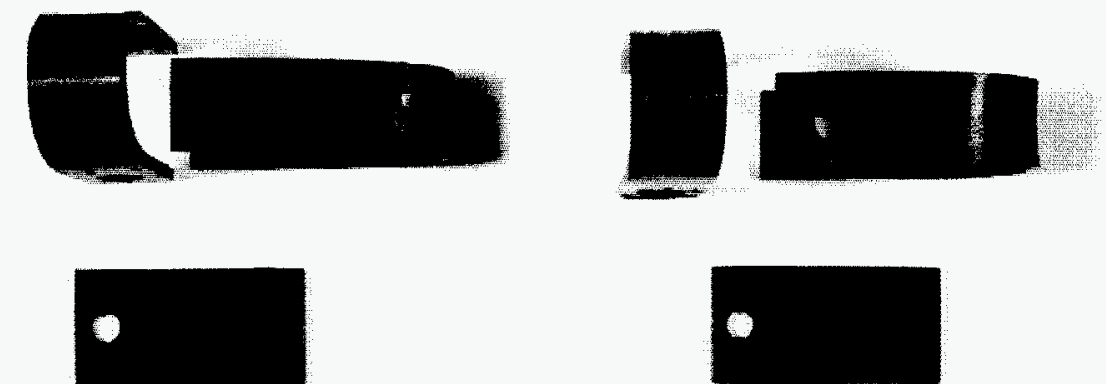

Waterline

Solution \#6

Immersed

Figure C.6 Solution 6: Representative Specimens After Removal from Test Solution (no cleaning) 
WHC-SD-WM-TI-765, Rev 0
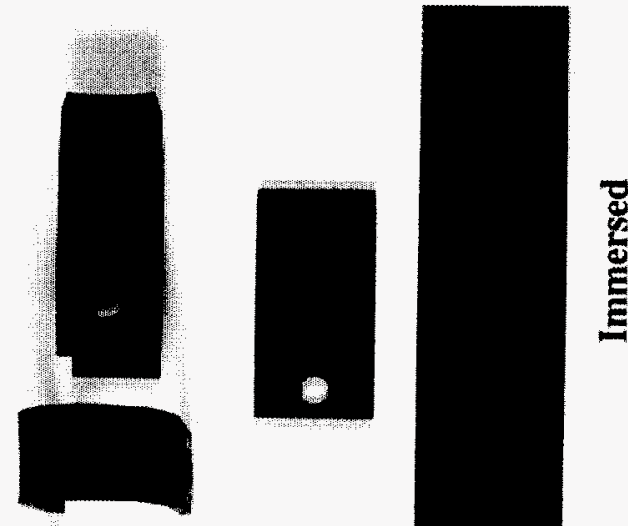

些

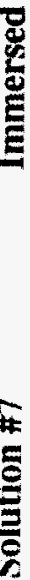

을

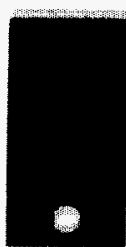

高

$\stackrel{5}{a}$
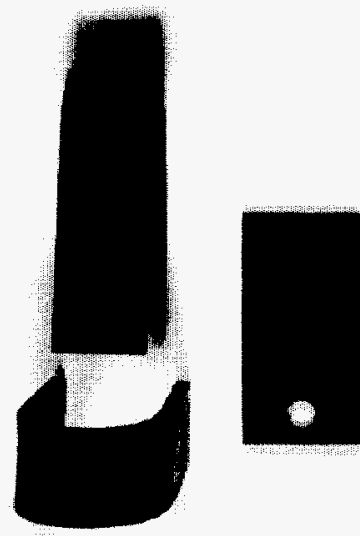

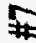

톨

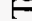

要

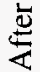

竞

莕

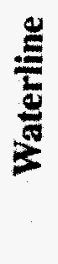

$\dot{r}$

을

0

몬 

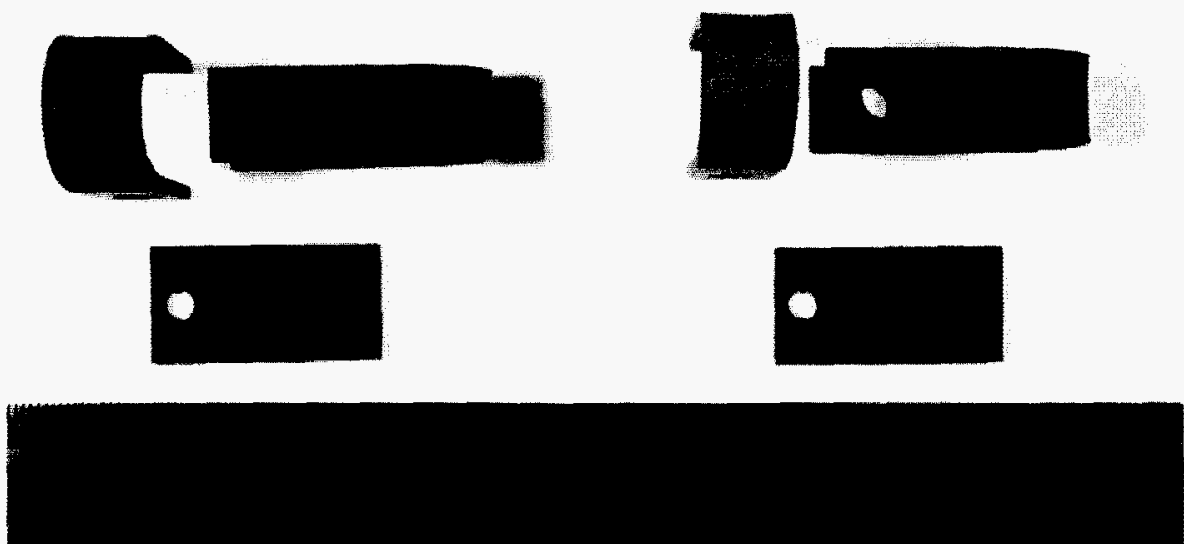

Waterline Solution \#8 Immersed

Figure C.8 Solution 8: Representative Specimens After Removal from Test Solution (no cleaning) 

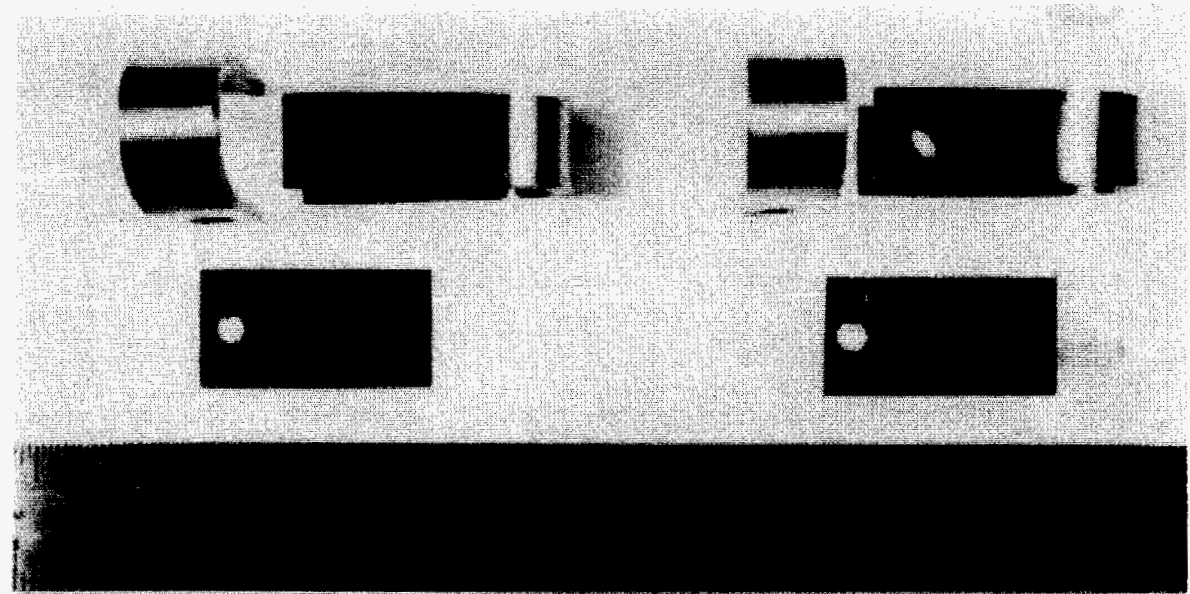

Waterline

Solution $\$ 9$

Inmersed

Figure C.9 Solution 9: Representative Specimens After Removal from Test Solution (no cleaning) 
WHC-SD-WM-TI-765, Rev 0

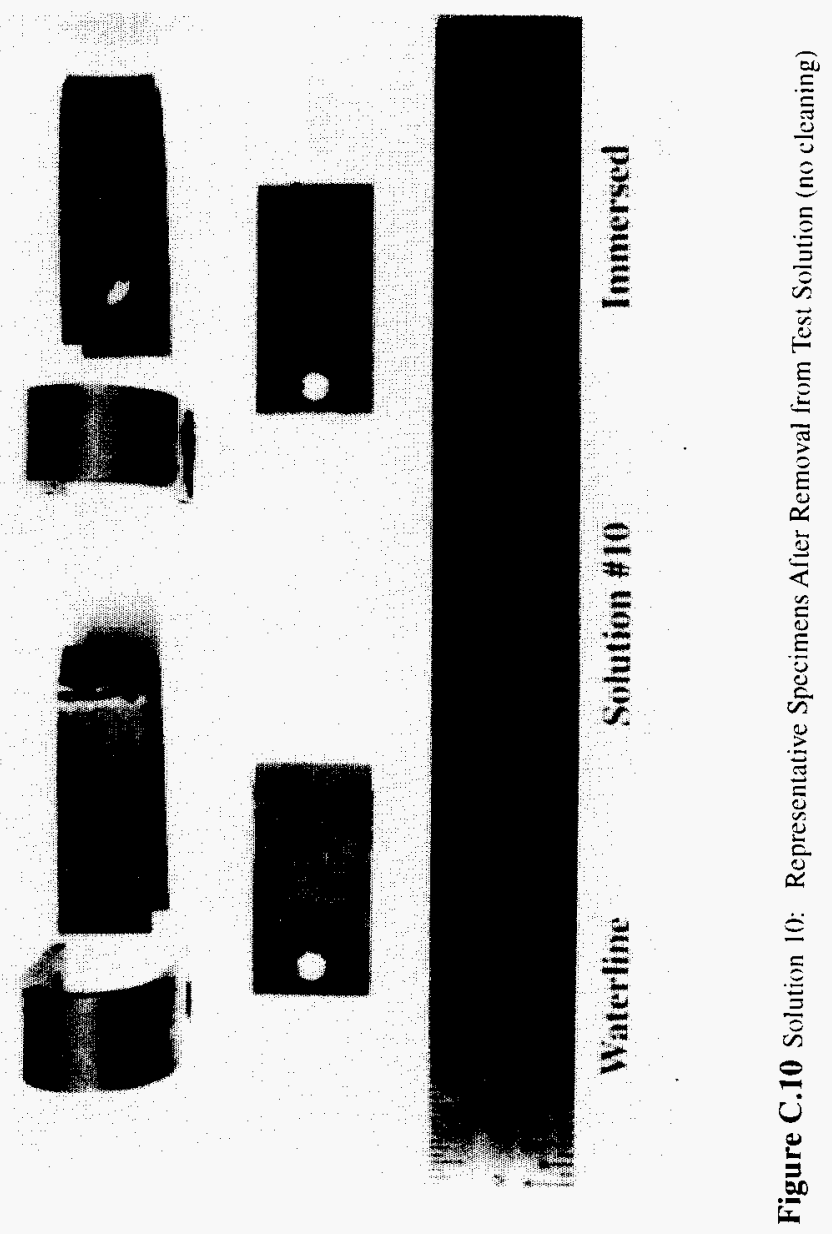

C.10 


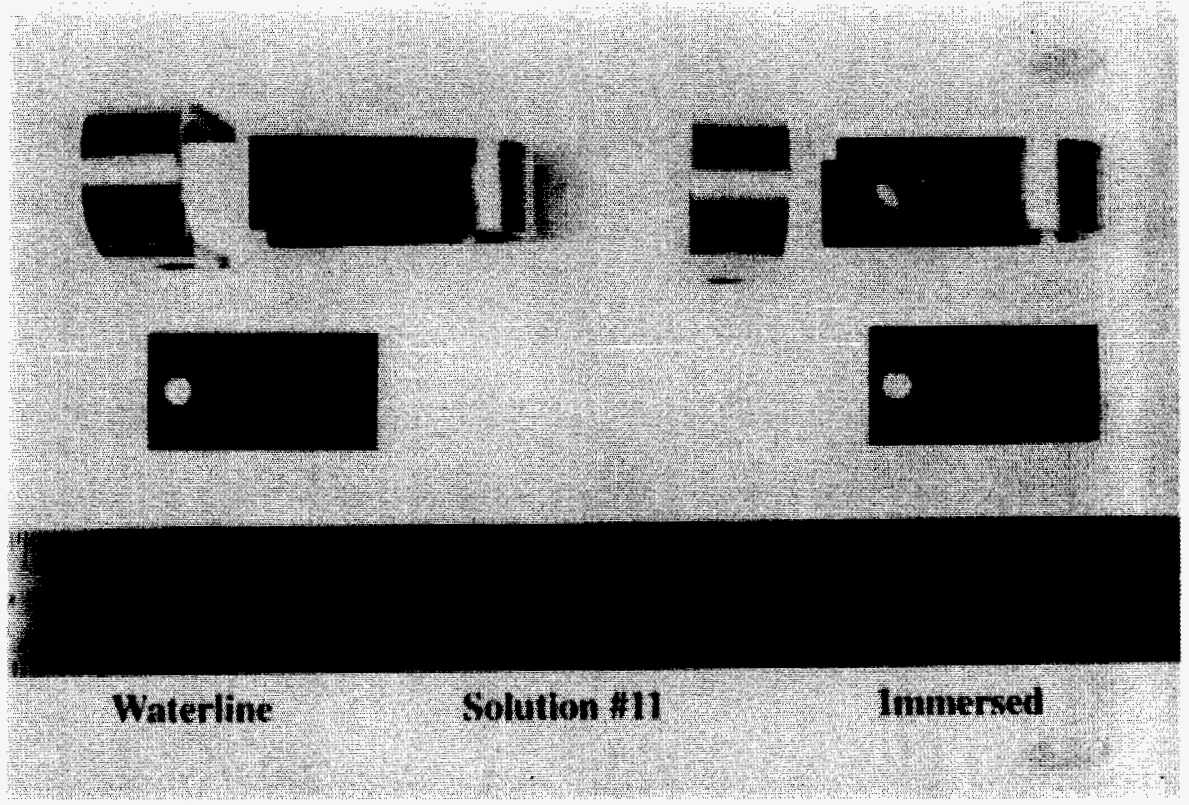

Figure C.11 Solution 11: Representative Specimens After Removal from Test Solution (no cleaning) 
WHC-SD-WM-TI-765, Rev 0
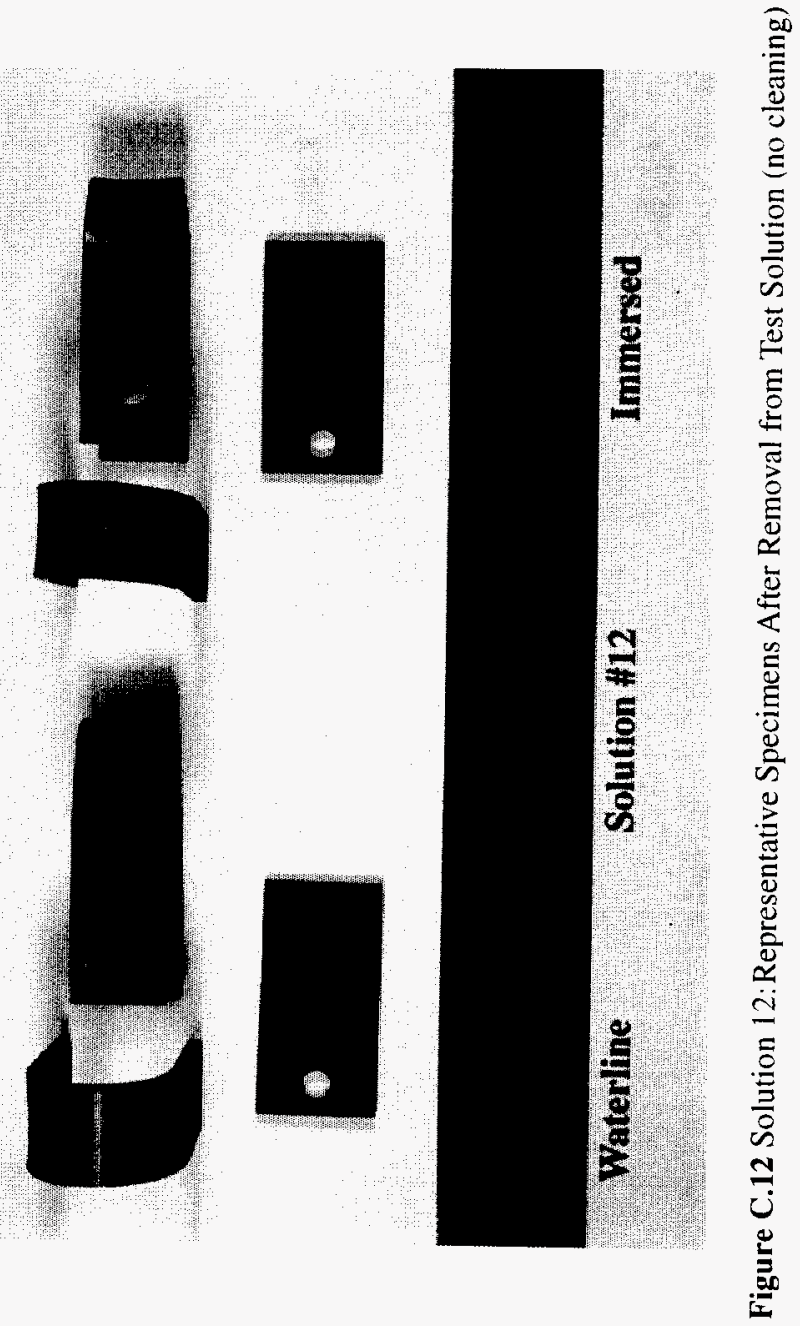

C. 12 
WHC-SD-WM-TI-765, Rev 0
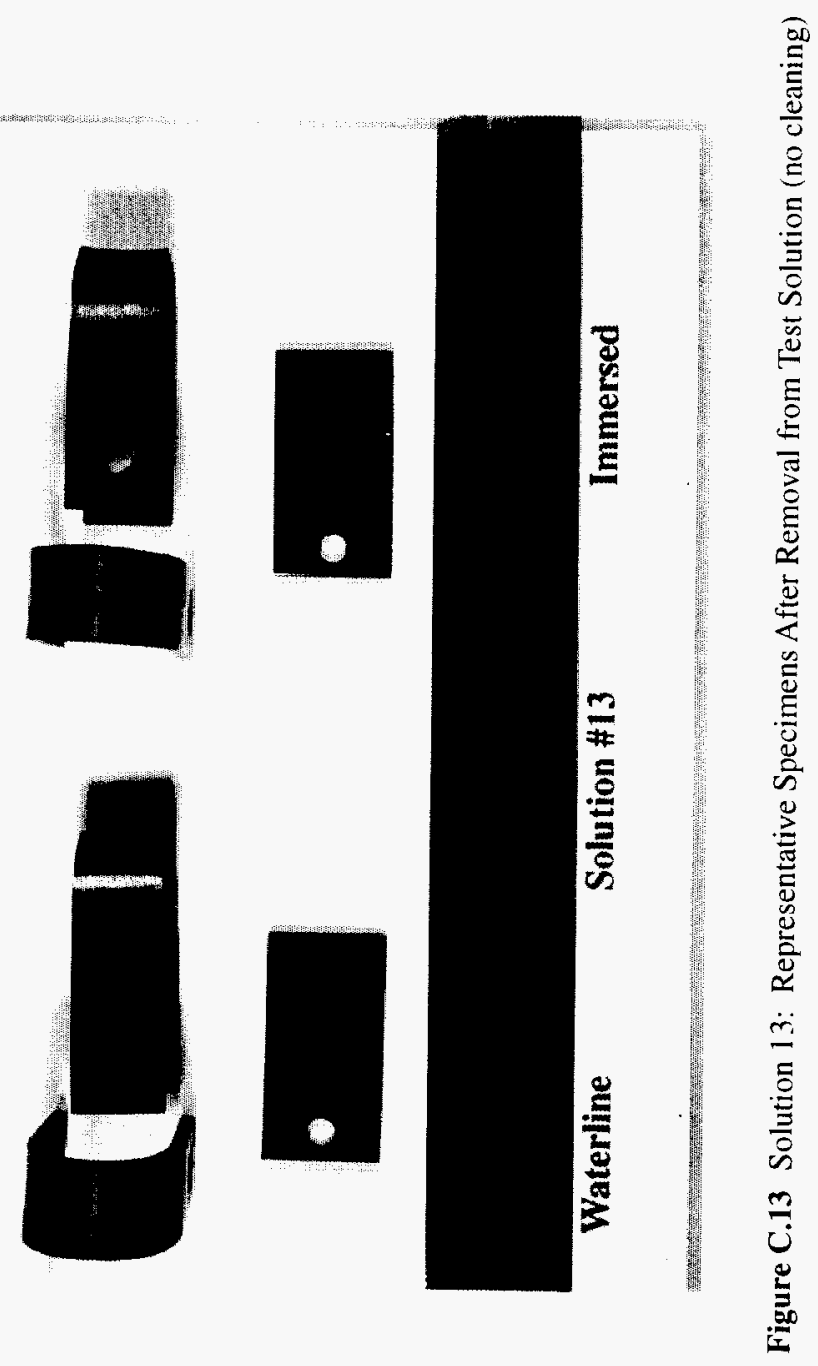

C. 13 

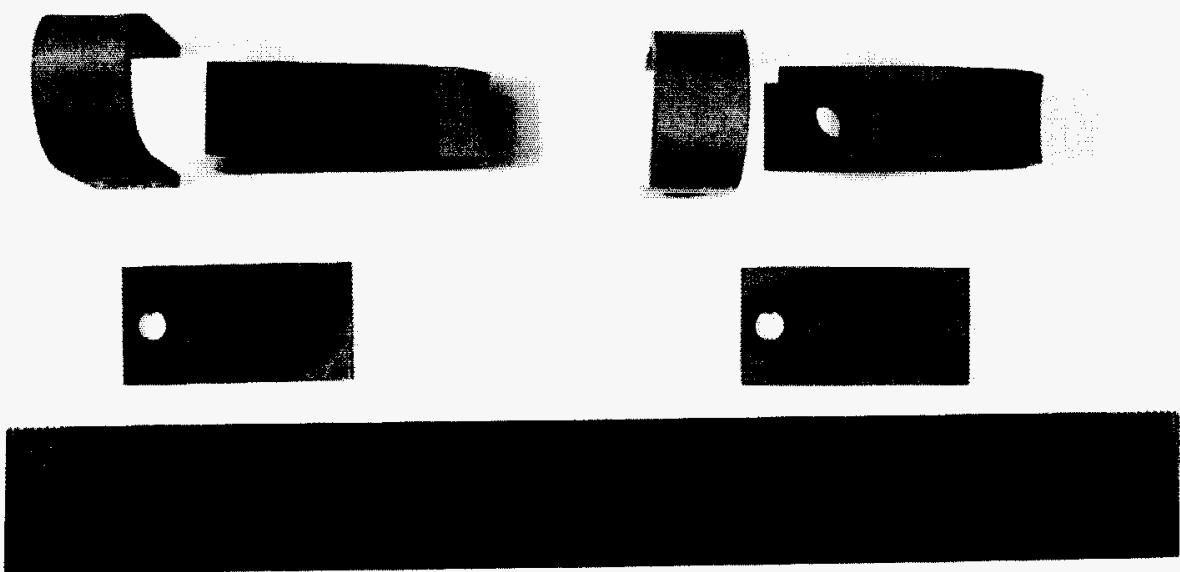

Waterline

Solution \#14

Immersed

Figure C.14 Solution 14: Representative Specimens After Removal from Test Solution (no cleaning) 
WHC-SD-WM-TI-765, Rev 0

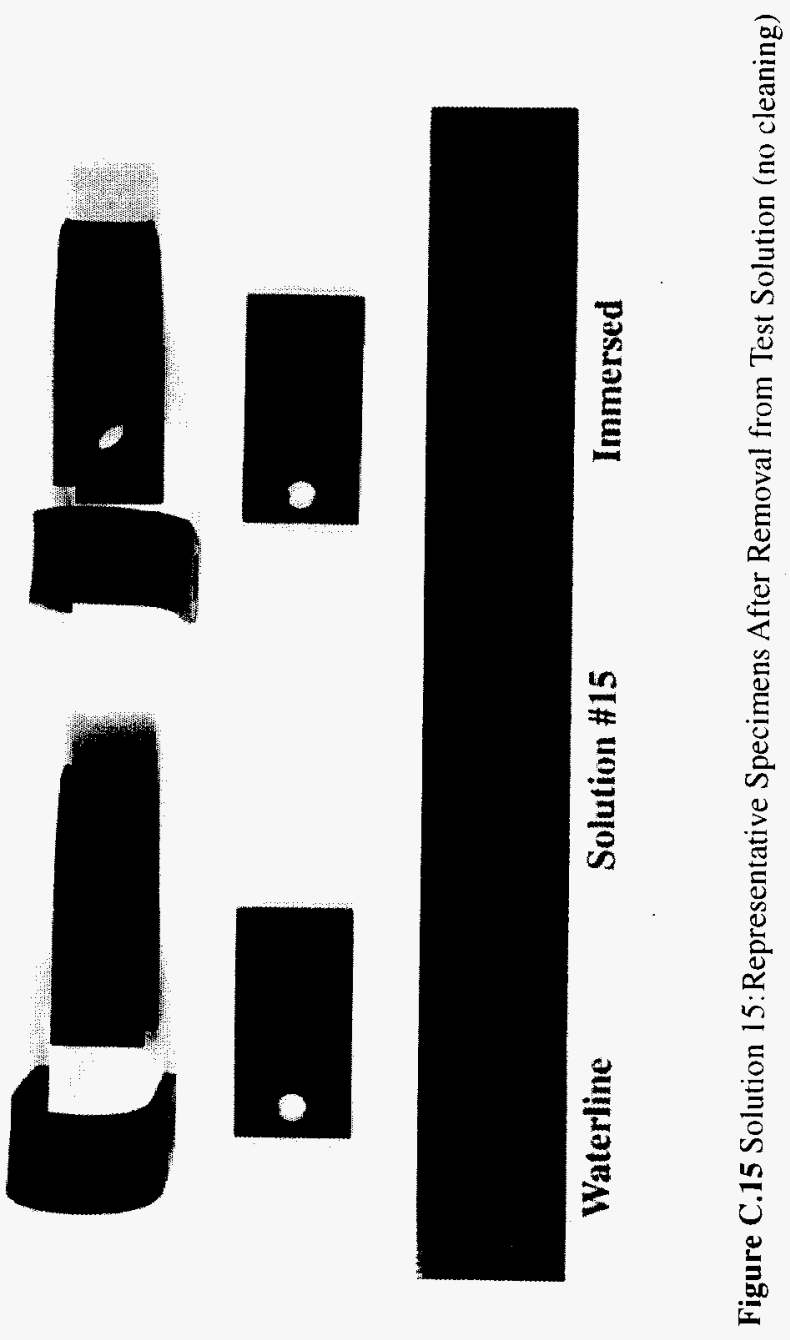

C. 15 

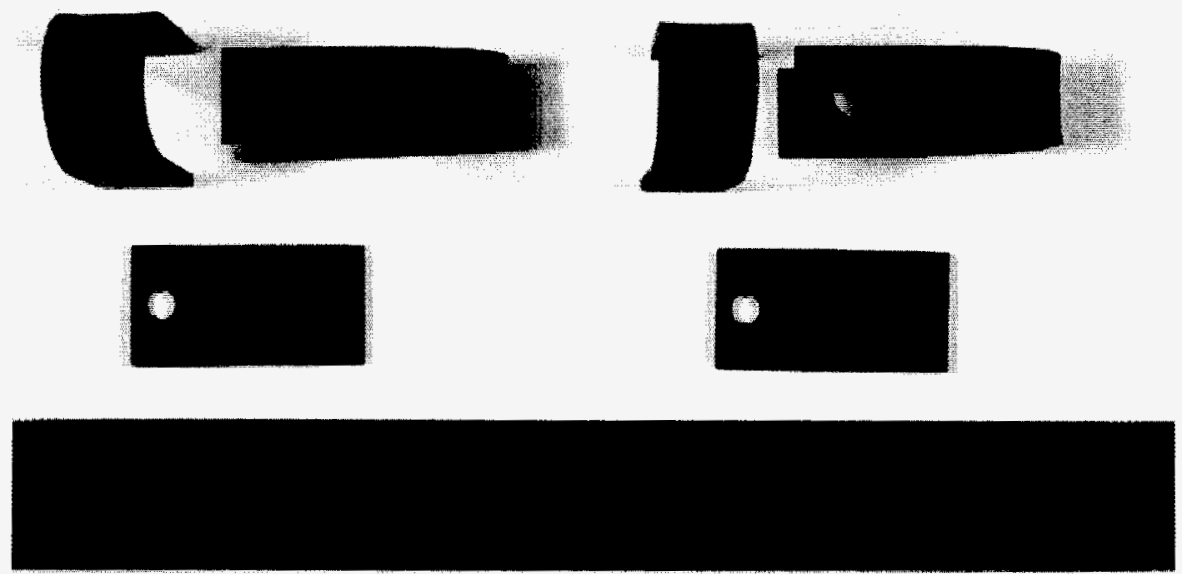

Waterline

Solution \#16

Immersed

Figure C.16 Solution 16: Representative Specimens After Removal from Test Solution (no cleaning) 
WHC-SD-WM-TI-765, Rev 0

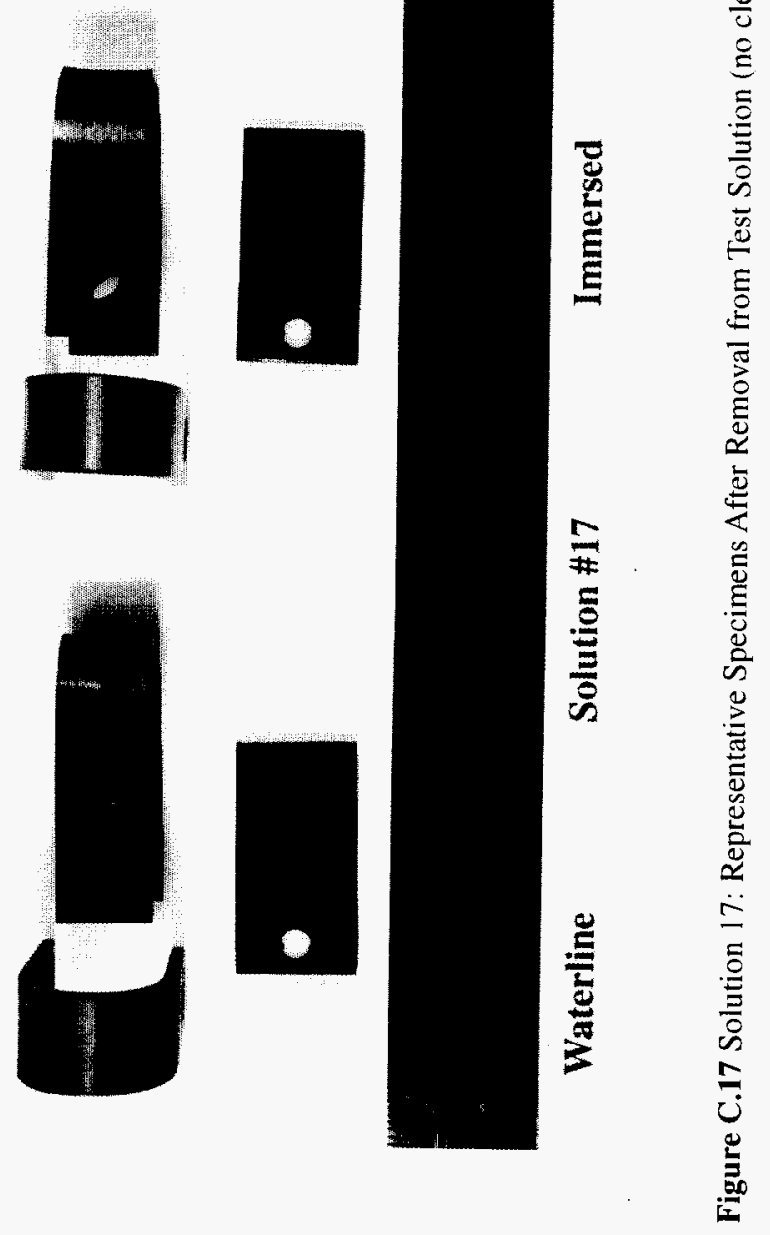

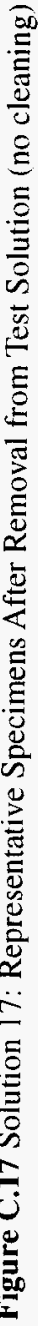


WHC-SD-WM-TI-765, Rev 0

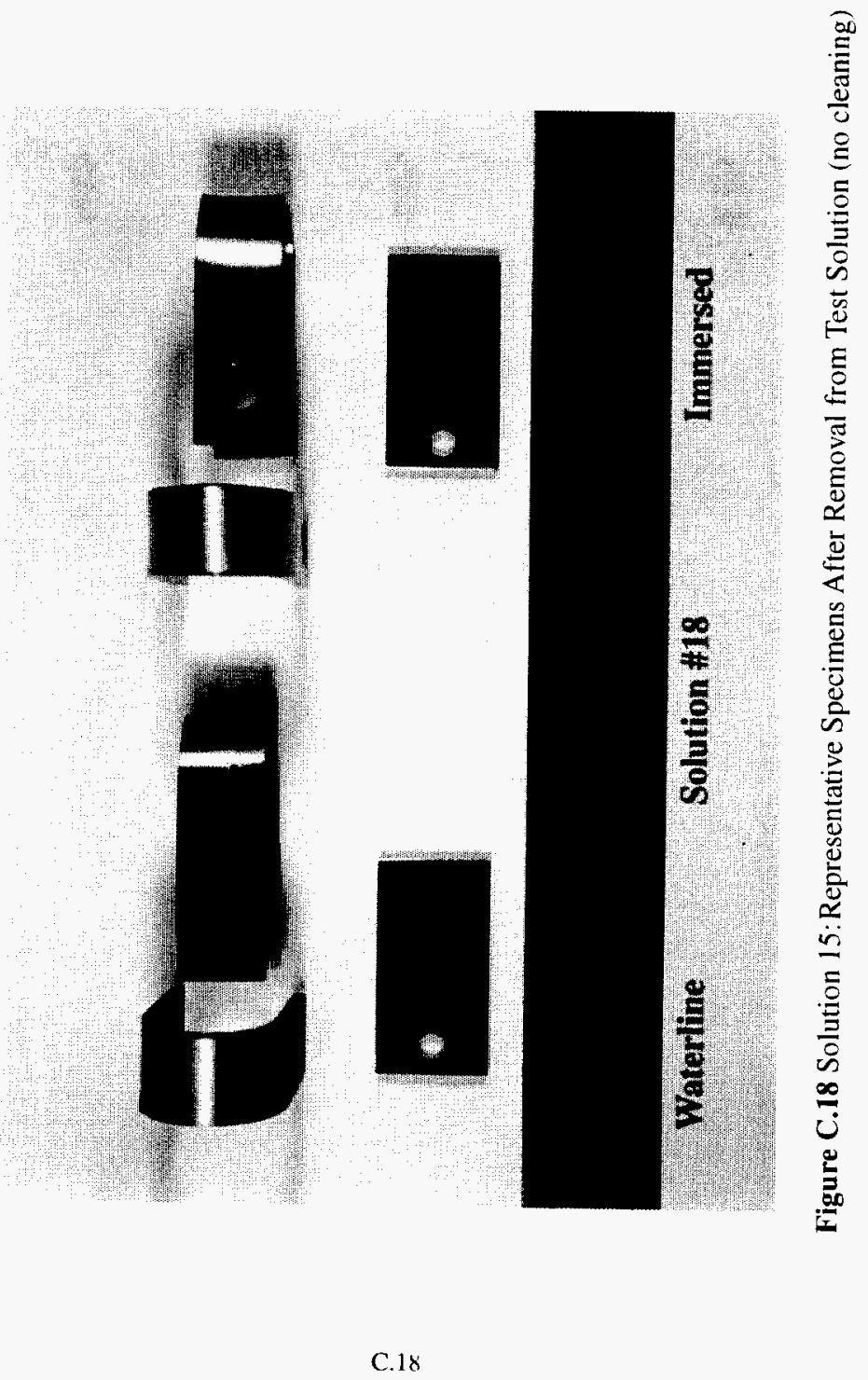



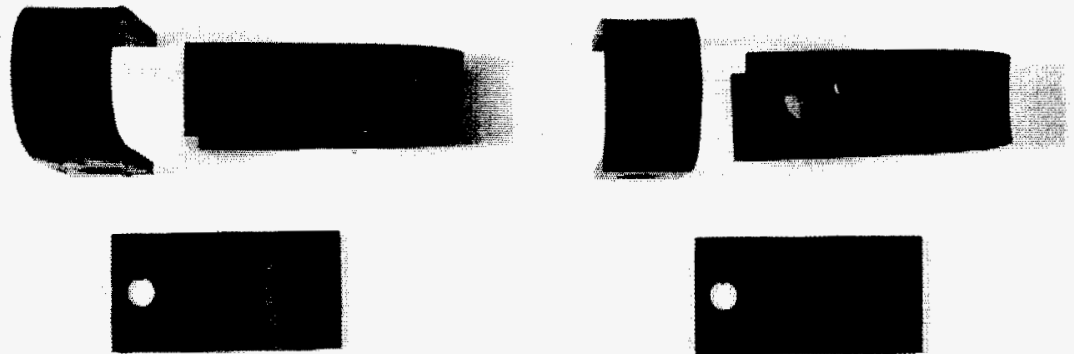

\section{Waterline} Solution \#19

Immersed

Figure C.19 Solution 19: Representative Specimens After Removal from Test Solution (no cleaning) 
WHC-SD-WM-TI-765, Rev 0

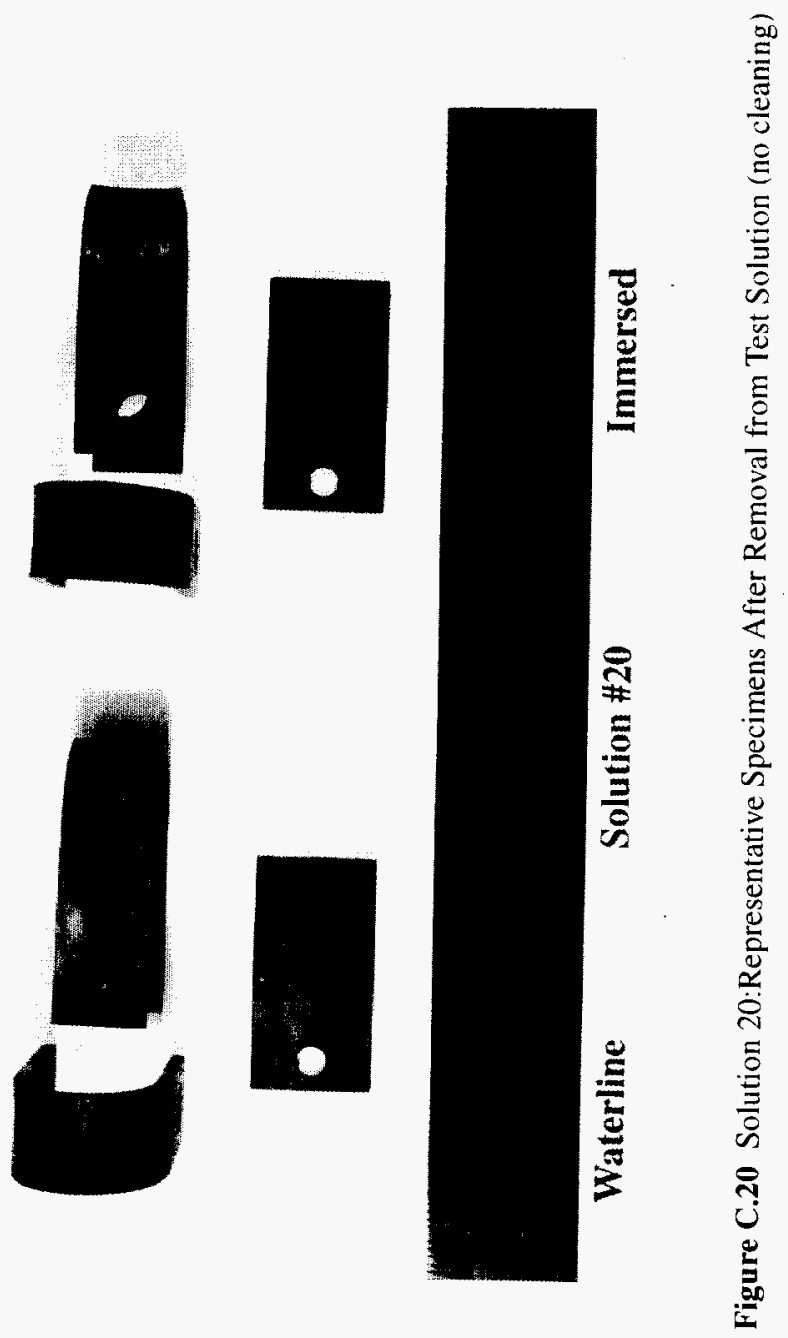


WHC-SD-WM-TI-765, Rev 0

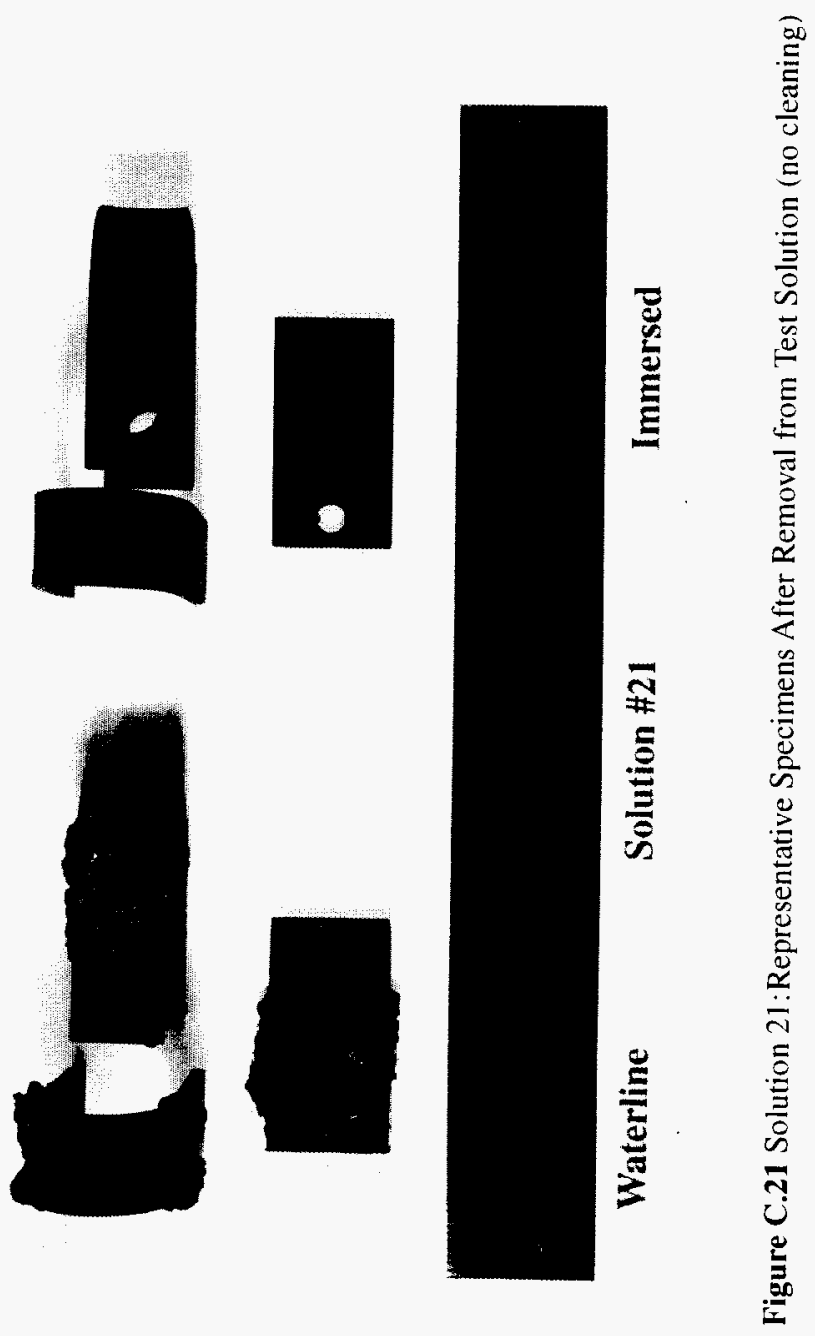

C.21 

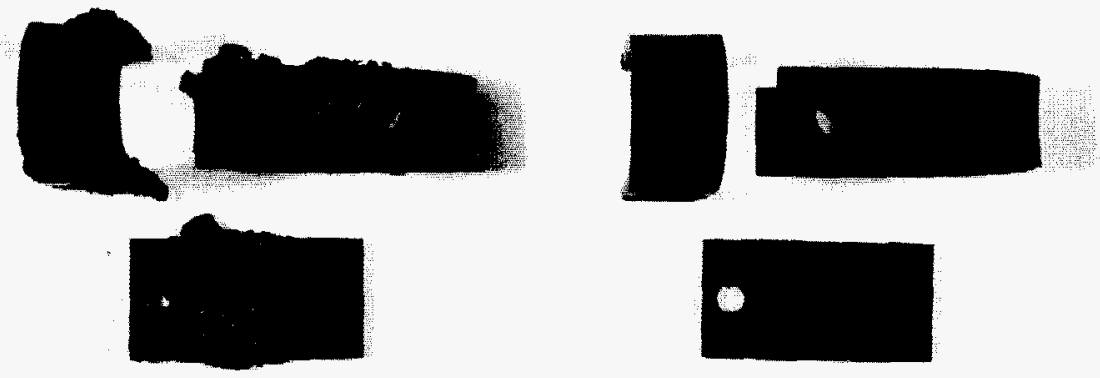

3

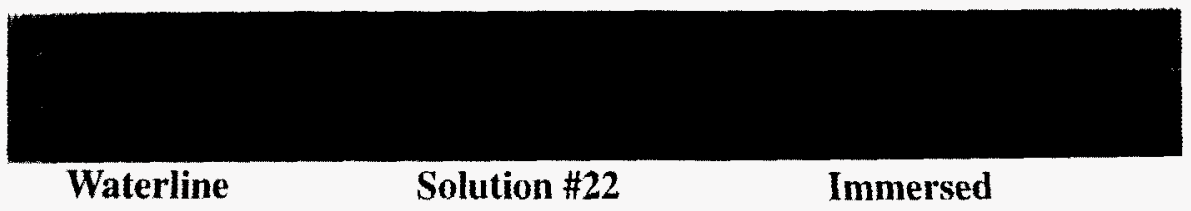

Figure C.22 Solution 22: Representative Specimens After Removal from Test Solution (no cleaning) 

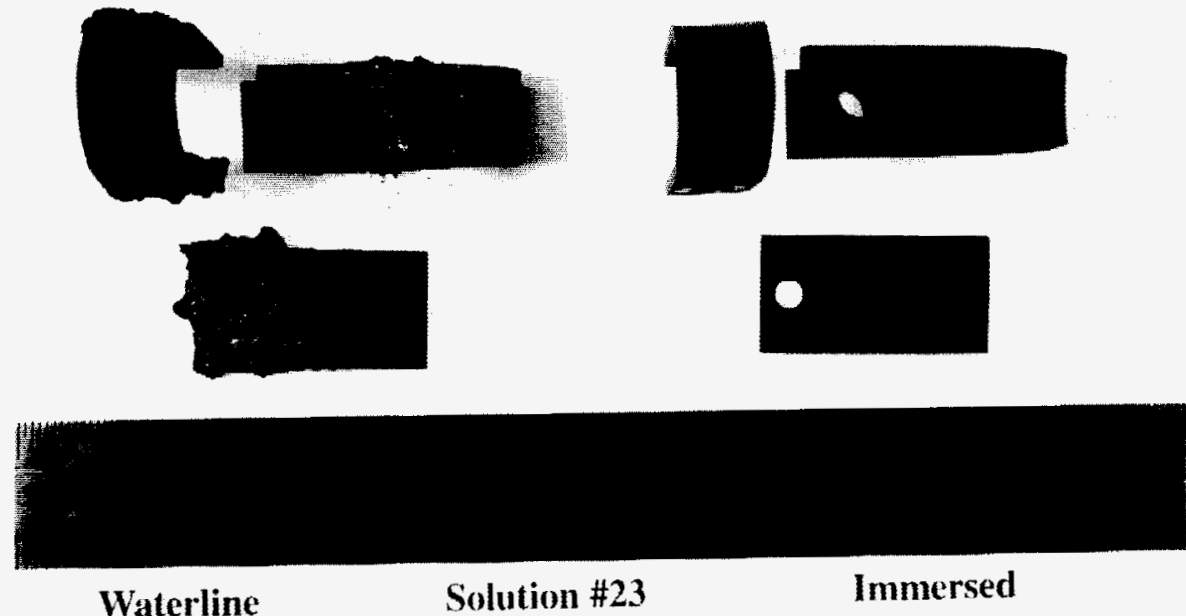

Figure C.23 Solution 23: Representative Specimens After Removal from Test Solution (no cleaning) 
WHC-SD-WM-TI-765, Rev 0

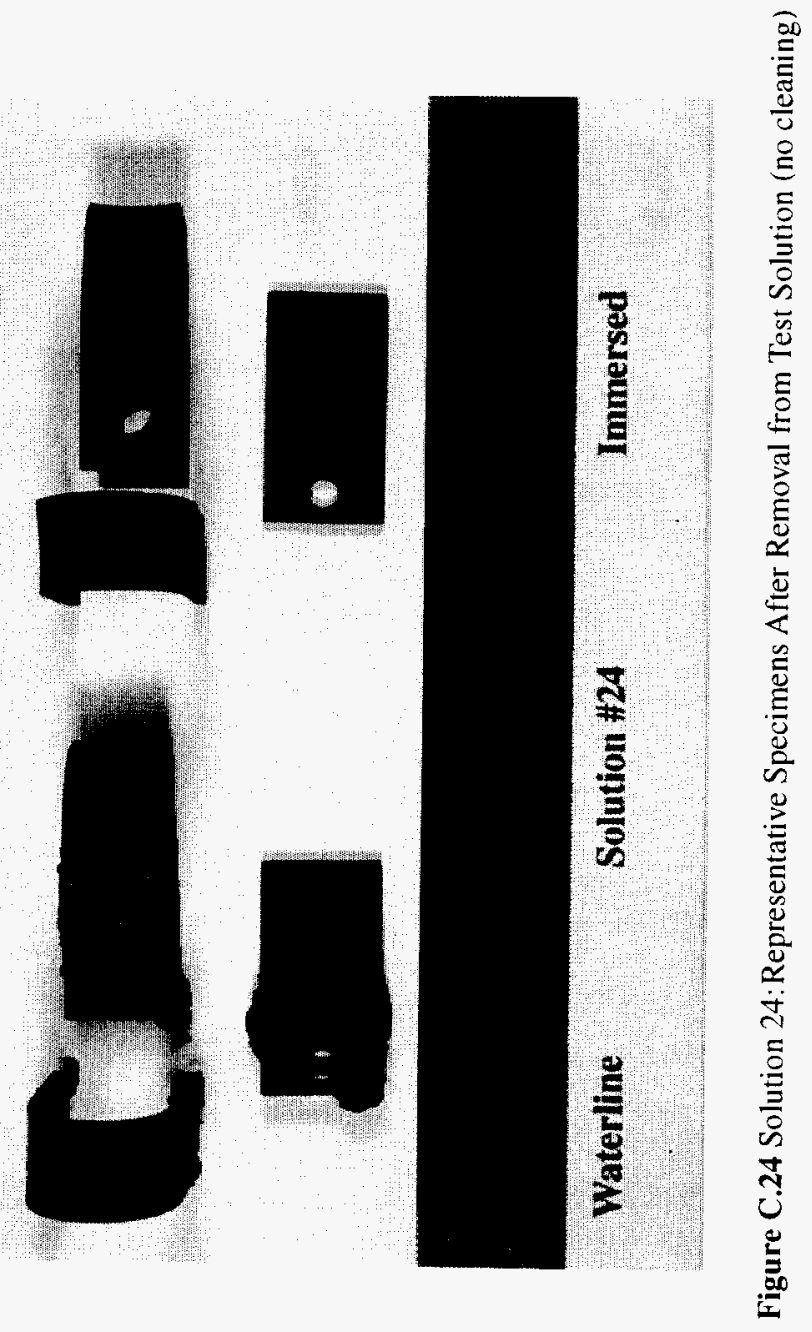


WHC-SD-WM-TI-765, Rev 0

APPENDIX D: WEIGHT LOSS DATA

D- $\mathbf{j}$ 
TABLE.XLS

\begin{tabular}{|c|c|c|c|c|c|c|c|c|c|}
\hline & & & Soln \#23 & & & & & & \\
\hline Type & Location & Spec ID\# & Starting & Post Wt & Wt. Loss & Specimen & Corr Rate & Aver Corr & \\
\hline & & & Wt., g & $\underline{g}$ & & Area, cm2 & $\mathrm{mm} / \mathrm{y}$ & Rate, $\overline{\mathrm{mm}} / \mathrm{y}$ & \\
\hline Corrosion & Liquid & 482 & 30.6060 & 30.5587 & 0.0458 & 30.4256 & $3.81 \mathrm{E}-03$ & & \\
\hline Corrosion & Liquid & 483 & 30.7166 & 30.6738 & 0.0413 & 30.3302 & 3.45E-03 & $3.84 \mathrm{E}-03$ & \\
\hline Corrosion & Liquid & 484 & 30.7570 & 30.7038 & 0.0517 & 30.7037 & $4.26 \mathrm{E}-03$ & & \\
\hline Corrosion & Vapor & 485 & 31.0223 & 24.5082 & 6.4506 & 30.6268 & 5.33E-01 & & \\
\hline Corrosion & Vapor & $48 \overline{6}$ & 31.0413 & 24.5082 & 6.4696 & 30.7409 & 5.33E-01 & $5.22 \mathrm{E}-01$ & \\
\hline Corrosion & Vapor & 487 & 30.6167 & 24.5082 & 6.0450 & 30.5375 & $5.01 \mathrm{E}-01$ & & \\
\hline U-bend & Liquid & 337 & 56.1089 & 55.9888 & 0.1116 & 56.9999 & $4.96 \mathrm{E}-03$ & & \\
\hline U-bend & Liquid & 338 & 56.6890 & 56.5763 & 0.1042 & 57.5521 & $4.58 \mathrm{E}-03$ & $4.76 \mathrm{E}-\overline{\mathrm{O}}$ & \\
\hline U-bend & Liquid & 339 & $5 \overline{6.4222}$ & 56.3064 & 0.1073 & 57.2981 & $4.74 \mathrm{E}-03$ & & \\
\hline U-bend & Vapor & 340 & 55.8168 & not cleaned & & & & & \\
\hline U-bend & Vapor & 341 & 55.4771 & not cleaned & & & & & \\
\hline U-bend & Vapor & 342 & 56.0766 & not cleaned & & & & & \\
\hline & & & Soln \#24 & & & & & & \\
\hline Type & Location & Spec ID\# & Starting & Post Wt & Wt. Loss & Specimen & Corr Rate & Aver Corr & \\
\hline & & & Wt., g & $g$ & & Area, $\mathrm{cm} 2$ & $\mathrm{~mm} / \mathrm{y}$ & Rate, $\mathrm{mm} / \mathrm{y}$ & \\
\hline Corrosion & Liquid & 488 & 30.8237 & 30.7653 & 0.0569 & 30.5867 & $4.71 \mathrm{E}-03$ & & \\
\hline Corrosion & Liquid & 489 & 30.8381 & 30.7819 & 0.0547 & 30.6750 & $4.51 \mathrm{E}-03$ & $4.56 \mathrm{E}-03$ & \\
\hline Corrosion & Liquid & 490 & 30.5760 & 30.5204 & 0.0541 & 30.6673 & $4.47 \mathrm{E}-03$ & & \\
\hline Corrosion & Vapor & 491 & 30.2074 & 23.9074 & $\overline{6} .2365$ & 30.5578 & $5.17 \mathrm{E}-01$ & & \\
\hline Corrosion & Vapor & 492 & 30.8632 & 28.7767 & 2.0230 & 30.7221 & $1.67 \mathrm{E}-01$ & 2.69E-01 & \\
\hline Corrosion & Vapor & 493 & 30.4711 & 28.9194 & 1.4882 & 30.5720 & $1.23 \mathrm{E}-01$ & & \\
\hline U-bend & Liquid & 343 & 55.5618 & 55.4589 & 0.0944 & 56.4791 & $4.23 \mathrm{E}-03$ & & \\
\hline U-bend & Liquid & 344 & 55.8338 & 55.7294 & 0.0959 & 56.7381 & $4.28 \mathrm{E}-03$ & $4.30 \mathrm{E}-\mathrm{O3}$ & \\
\hline U-bend & Liquid & 345 & 55.3499 & 55.2436 & 0.0978 & 56.2774 & $4.40 \mathrm{E}-03$ & & \\
\hline U-bend & Vapor & 346 & 55.3808 & not cleaned & & & & & \\
\hline U-bend & Vapor & 347 & 55.3628 & not cleaned & & & & & \\
\hline U-bend & Vapor & 348 & 55.8844 & not cleaned & & & & & \\
\hline
\end{tabular}


TABLE.XLS

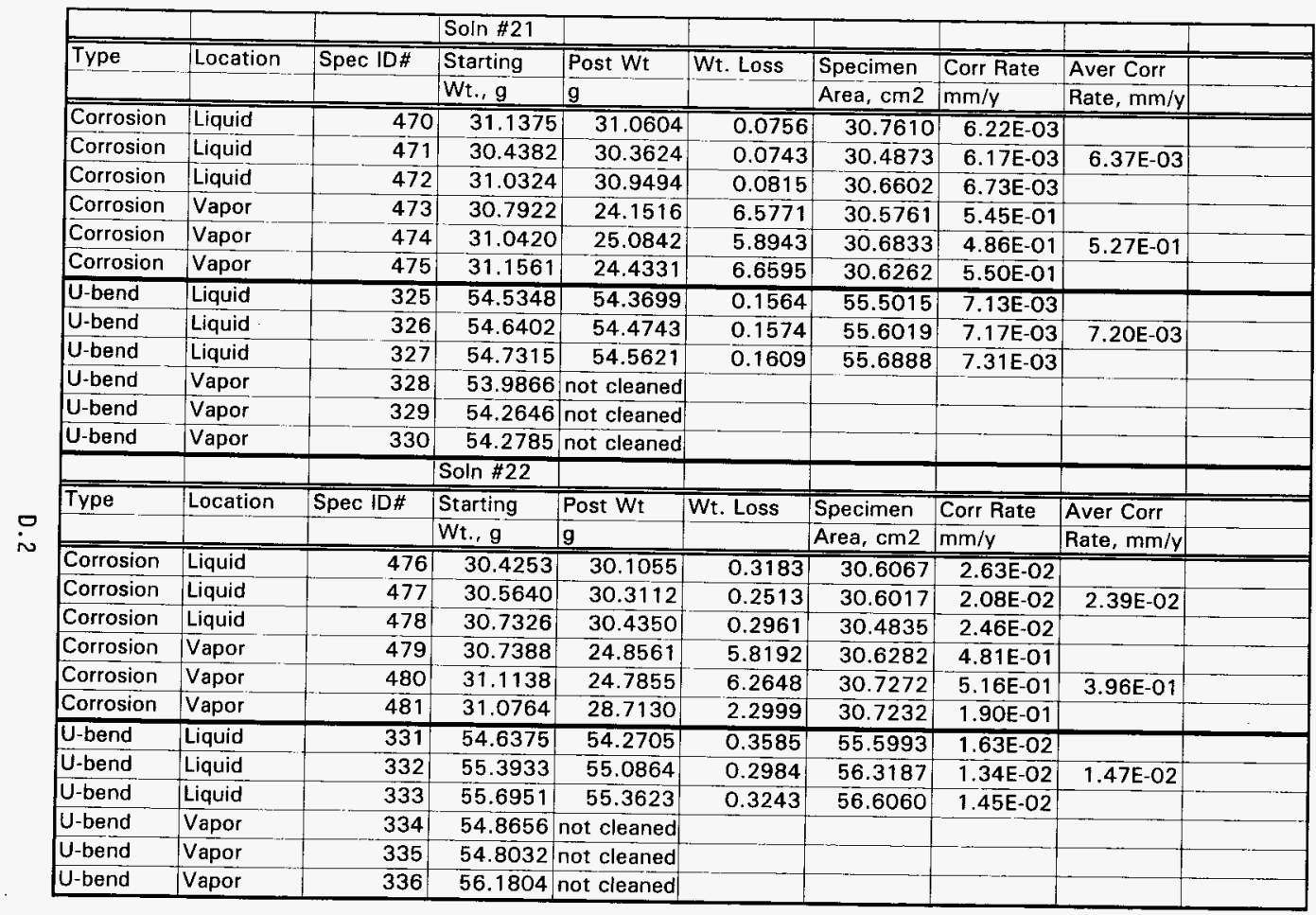


TABLE.XLS

\begin{tabular}{|c|c|c|c|c|c|c|c|c|c|}
\hline & & & Soln \#19 & & & & & & \\
\hline Type & Location & Spec ID\# & Starting & Post Wt & Wt. Loss & Specimen & Corr Rate & Aver Corr & \\
\hline & & & Wt., g & $\mathrm{g}$ & & Area, $\mathrm{cm} 2$ & $\mathrm{~mm} / \mathrm{y}$ & Rate, $\mathrm{mm} / \mathrm{y}$ & \\
\hline Corrosion & Liquid & 458 & 30.6566 & 30.6275 & 0.0276 & $30.64 \overline{41}$ & $2.28 \mathrm{E}-\mathrm{O} 3$ & & \\
\hline Corrosion & Liquid & 459 & 30.7306 & 30.7005 & 0.0286 & $30 . \overline{5939}$ & $2.37 \mathrm{E}-03$ & $2.25 \mathrm{E}-03$ & \\
\hline Corrosion & Liquid & 460 & 30.1905 & 30.1639 & 0.0251 & 30.4172 & $2.09 \mathrm{E}-03$ & & \\
\hline Corrosion & Vapor & 461 & 31.0874 & 31.0644 & 0.0215 & 30.7437 & $1.77 \mathrm{E}-03$ & & \\
\hline Corrosion & Vapor & 462 & 30.8333 & 30.8069 & 0.0249 & 30.6572 & $2.06 \mathrm{E}-03$ & 1.92E-03 & \\
\hline Corrosion & Vapor & 463 & 30.8541 & 30.8290 & 0.0236 & 30.6869 & $1.95 \bar{E}-03$ & & \\
\hline U-bend & Liquid & 313 & 54.4216 & 54.3645 & 0.0486 & 55.3938 & $2.22 \mathrm{E}-\mathrm{O} 3$ & & \\
\hline U-bend & Liquid & 314 & 54.7925 & 54.7317 & 0.0523 & 55.7468 & $2.38 \mathrm{E}-03$ & $2.31 \mathrm{E}-03$ & \\
\hline U-bend & Liquid & 315 & 54.7721 & 54.7121 & 0.0515 & 55.7274 & $2.34 \mathrm{E}-03$ & & \\
\hline U-bend & Vapor & 316 & 54.5736 & 54.5212 & 0.0439 & 55.5385 & $2.00 \mathrm{E}-03$ & & \\
\hline U-bend & Vapor & 317 & 54.9822 & 54.9231 & 0.0506 & 55.9274 & $2.29 \mathrm{E}-03$ & $2.21 \mathrm{E}-03$ & \\
\hline U-bend & Vapor & 318 & 55.4440 & 55.3837 & 0.0518 & 56.3670 & $2.33 E-03$ & & \\
\hline & & & Soln \#20 & & & & & & \\
\hline Type & Location & Spec ID\# & Starting & Post Wt & Wt. Loss & Specimen & Corr Rate & Aver Corr & \\
\hline & & & Wt., $\mathrm{g}$ & $g$ & & Area, $\mathrm{cm} 2$ & $\mathrm{~mm} / \mathrm{y}$ & Rate, $\mathrm{mm} / \mathrm{y}$ & \\
\hline Corrosion & Liquid & 404 & 30.8514 & $30.825 \overline{9}$ & 0.0240 & 30.6927 & $1.98 \mathrm{E}-03$ & & \\
\hline Corrosion & Liquid & 465 & 30.9331 & 30.9058 & 0.0258 & 30.6851 & $2.13 \mathrm{E}-03$ & $2.10 \mathrm{E}-\mathrm{O} 3$ & \\
\hline Corrosion & Liquid & 466 & 30.8357 & 30.8076 & $0.026 \overline{6}$ & 30.5695 & $2.20 \mathrm{E}-03$ & & \\
\hline Corrosion & Vapor & 467 & 31.2313 & 31.1886 & 0.0412 & 30.7933 & $3.39 \mathrm{E}-03$ & & \\
\hline Corrosion & Vapor & 468 & 30.3659 & 30.3273 & 0.0371 & 30.4859 & $3.08 \mathrm{E}-03$ & $3.16 \mathrm{E}-03$ & \\
\hline Corrosion & Vapor & 469 & 30.7851 & 30.7472 & 0.0364 & 30.6894 & 3.00E-03 & & \\
\hline U-bend & Liquid & 319 & 54.5503 & 54.4981 & 0.0437 & 55.5163 & $1.99 \mathrm{E}-03$ & & \\
\hline U-bend & Liquid & 320 & 55.7314 & 55.6768 & 0.0461 & 56.6406 & $2.06 \mathrm{E}-03$ & $2.02 \mathrm{E}-03$ & \\
\hline U-bend & Liquid & 321 & 55.9754 & 55.9218 & 0.0451 & 56.8728 & $2.01 \mathrm{E}-03$ & & \\
\hline U-bend & Vapor & 322 & 54.8053 & 54.7387 & 0.0581 & 55.7590 & $2.64 \mathrm{E}-03$ & & \\
\hline U-bend & Vapor & 323 & 54.8818 & 54.8164 & 0.0569 & 55.8319 & $2.58 \mathrm{E}-03$ & $2.5 \overline{5} \mathrm{E}-03$ & \\
\hline U-bend & Vapor & 324 & 54.0298 & 53.9684 & 0.0529 & 55.0208 & $2.43 \mathrm{E}-03$ & & \\
\hline
\end{tabular}


TABLE.XLS

\begin{tabular}{|c|c|c|c|c|c|c|c|c|c|}
\hline & & & Soln \#17 & & & & & & \\
\hline Type & Location & Spec ID\# & Starting & Post Wt & Wt. Loss & Specimen & Corr Rate & Aver Corr & \\
\hline & & & Wt., g & $g$ & & Area, $\mathrm{cm} 2$ & $\mathrm{~mm} / \mathrm{v}$ & Rate, $\mathrm{mm} / \mathrm{y}$ & \\
\hline Corrosion & Liquid & -446 & 30.8866 & 30.8713 & 0.0138 & 30.7225 & $1.14 \mathrm{E}-03$ & & \\
\hline Corrosion & Liquid & 447 & 30.5311 & 30.5162 & 0.0134 & 30.6372 & 1.11E-03 & $1.12 \mathrm{E}-03$ & \\
\hline Corrosion & Liquid & 448 & 30.0649 & 30.0499 & 0.0135 & 30.5583 & $1.12 \mathrm{E}-03$ & & \\
\hline Corrosion & Vapor & 449 & 30.3289 & 30.3041 & 0.0233 & 30.5958 & $1.93 \mathrm{E}-03$ & & \\
\hline Corrosion & Vapor & $4 \overline{50}$ & 30.4025 & 30.3777 & 0.0233 & 30.5613 & $1.93 \mathrm{E}-03$ & $1.83 \mathrm{E}-\overline{0}$ & \\
\hline Corrosion & Vapor & 451 & 30.6479 & 30.6265 & $0 . \overline{0} 199$ & 30.6199 & $1.65 \mathrm{E}-\overline{03}$ & & \\
\hline U-bend & Liquid & 301 & 55.1596 & 55.1277 & 0.0234 & 56.0963 & $1.06 \mathrm{E}-03$ & & \\
\hline U-bend & Liquid & 302 & 55.7649 & 55.7342 & 0.0222 & 56.6725 & $9.92 E-04$ & $1.03 \mathrm{E}-03$ & \\
\hline U-bend & Liquid & 303 & 54.9133 & 54.8818 & 0.0230 & 55.8618 & 1.04E-03 & & \\
\hline U-bend & Vapor & 304 & 55.2329 & 55.1685 & 0.0559 & 56.1661 & $2.52 \mathrm{E}-03$ & & \\
\hline U-bend & Vapor & 305 & 55.0327 & 54.9738 & 0.0504 & 55.9755 & $2.28 \mathrm{E}-03$ & $2.41 \mathrm{E}-03$ & \\
\hline U-bend & Vapor & 306 & 55.0744 & 55.0124 & 0.0535 & 56.0152 & $2.42 \mathrm{E}-03$ & & \\
\hline & & & Soln \#18 & & & & & & \\
\hline Type & Location & Spec ID\# & Starting & Post Wt & Wt. Loss & Specimen & Corr Rate & Aver Corr & \\
\hline & & & Wt., g & $g$ & & Area, $\mathrm{cm} 2$ & $\mathrm{~mm} / \mathrm{s}$ & Rate, $\mathrm{mm} / \mathrm{y}$ & \\
\hline Corrosion & Liquid & 452 & 30.1635 & 30.1589 & 0.0031 & 30.5661 & $2.57 \mathrm{E}-04$ & & \\
\hline Corrosion & Liquid & 453 & 30.4010 & 30.3980 & 0.0015 & 30.5392 & 1.24E-04 & $1.71 \mathrm{E}-04$ & \\
\hline Corrosion & Liquid & 454 & 30.1610 & 30.1579 & 0.0016 & 30.5226 & $1.33 \mathrm{E}-04$ & & \\
\hline Corrosion & Vapor & 455 & 30.3221 & 30.2972 & 0.0234 & 30.5250 & $1.94 \mathrm{E}-03$ & & \\
\hline Corrosion & Vapor & 456 & 30.4546 & 30.4311 & 0.0220 & 30.5668 & $1.82 \mathrm{E}-03$ & $1.98 \mathrm{E}-03$ & \\
\hline Corrosion & Vapor & 457 & 30.5968 & $30.5 \overline{6} 88$ & 0.0265 & 30.6263 & $2.19 \mathrm{E}-03$ & & \\
\hline U-bend & Liquid & 307 & 55.8202 & 55.8128 & -0.0011 & 56.7251 & $-4.91 \mathrm{E}-05$ & & \\
\hline U-bend & Liquid & $30 \overline{8}$ & 55.7893 & 55.7850 & -0.0042 & 56.6957 & $-1.88 E-04$ & $-1.30 \mathrm{E}-04$ & \\
\hline U-bend & Liquid & 309 & 55.7094 & 55.7043 & -0.0034 & 56.6196 & $-1.52 \mathrm{E}-04$ & & \\
\hline U-bend & Vapor & 310 & 55.7220 & 55.6698 & 0.0437 & 56.6316 & $1.95 \mathrm{E}-03$ & & \\
\hline U-bend & Vapor & 311 & 55.6883 & 55.6392 & 0.0406 & 56.5996 & $1.82 \mathrm{E}-03$ & $1.81 \mathrm{E}-03$ & \\
\hline U-bend & Vapor & 312 & 55.8097 & 55.7643 & 0.0369 & 56.7151 & $1.65 \mathrm{E}-03$ & & \\
\hline
\end{tabular}


TABLE.XLS

\begin{tabular}{|c|c|c|c|c|c|c|c|c|c|}
\hline & & & Soln $\# 15$ & & & & & & \\
\hline Type & Location & Spec ID\# & Starting & Post Wt & Wt. Loss & Specimen & Corr Rate & Aver Corr & \\
\hline & & & Wt., $\mathrm{g}$ & $\mathrm{g}$ & & Area, $\mathrm{cm} 2$ & $\mathrm{~mm} / \mathrm{y}$ & Rate, $\mathrm{mm} / \mathrm{y}$ & \\
\hline Corrosion & Liquid & 434 & $30.4 \overline{218}$ & 30.3646 & 0.0557 & 30.6163 & $4.61 \mathrm{E}-03$ & & \\
\hline Corrosion & Liquid & 435 & 30.8250 & 30.7688 & 0.0547 & 30.5744 & $4.53 \mathrm{E}-03$ & $4.56 \mathrm{E}-03$ & \\
\hline Corrosion & Liquid & 436 & 30.7128 & 30.6564 & 0.0549 & 30.6366 & $4.54 \mathrm{E}-03$ & & \\
\hline Corrosion & Vapor & 437 & 30.1947 & 30.1587 & 0.0345 & 30.5138 & $2.86 \mathrm{E}-03$ & & \\
\hline Corrosion & Vapor & 438 & 30.6755 & 30.6424 & $0.031 \overline{6}$ & 30.5730 & $2.62 \mathrm{E}-03$ & $2.74 \mathrm{E}-03$ & \\
\hline Corrosion & Vapor & $43 \overline{9}$ & 30.3093 & 30.2748 & 0.0330 & $30.437 \overline{3}$ & $2.74 \mathrm{E}-03$ & & \\
\hline U-bend & Liquid & 289 & 55.7208 & 55.6207 & 0.0916 & 56.6305 & $4.09 E-03$ & & \\
\hline U-bend & Liquid & 290 & 55.4953 & 55.3945 & 0.0923 & 56.4158 & $4.14 \bar{E}-03$ & $4.15 \mathrm{E}-03$ & \\
\hline U-bend & Liquid & 291 & 55.1116 & 55.0097 & 0.0934 & 56.0506 & $4.22 \mathrm{E}-03$ & & \\
\hline U-bend & Vapor & 292 & 56.2337 & 56.1537 & 0.0715 & 57.1187 & $3.17 \mathrm{E}-03$ & & \\
\hline U-bend & Vapor & 293 & 55.3965 & 55.3251 & 0.0629 & 56.3218 & $2.83 \mathrm{E}-03$ & $3.00 \mathrm{E}-03$ & \\
\hline U-bend & Vapor & 294 & 53.9479 & 53.8741 & 0.0653 & $54.942 \overline{9}$ & $3.01 \mathrm{E}-03$ & & \\
\hline & & & Soln \#16 & & & & & & \\
\hline Type & Location & Spec ID\# & Starting & Post Wt & Wt. Loss & Specimen & Corr Rate & Aver Corr & \\
\hline & & & $W_{t}, \mathrm{~g}$ & $g$ & & Area, $\mathrm{cm} 2$ & $\mathrm{~mm} / \mathrm{y}$ & Rate, $\mathrm{mm} / \mathrm{y}$ & \\
\hline Corrosion & Liquid & 440 & 31.1207 & 31.0793 & 0.0399 & $30 . \overline{8018}$ & $3.28 \mathrm{E}-03$ & & \\
\hline Corrosion & Liquid & 441 & 30.5607 & 30.5181 & 0.0411 & 30.6228 & $3.40 \mathrm{E}-03$ & $3.34 \mathrm{E}-03$ & \\
\hline Corrosion & Liquid & 442 & 30.2506 & 30.2089 & 0.0402 & 30.5421 & $3.33 \mathrm{E}-03$ & & \\
\hline Corrosion & Vapor & 443 & 30.7500 & 30.7069 & 0.0416 & 30.6832 & $3.43 \mathrm{E}-03$ & & \\
\hline Corrosion & Vapor & 444 & 30.5862 & 30.5434 & 0.0413 & 30.6492 & $3.41 \mathrm{E}-03$ & $3.21 \mathrm{E}-03$ & \\
\hline Corrosion & Vapor & 445 & 31.0423 & 31.0070 & 0.0338 & $30.755 \overline{3}$ & $2.78 \mathrm{E}-03$ & & \\
\hline U-bend & Liquid & 295 & 55.5299 & 55.4503 & 0.0711 & 56.4488 & $3.19 \mathrm{E}-03$ & & \\
\hline$U$-bend & Liquid & 296 & 56.2014 & 56.1121 & 0.0808 & 57.0880 & $3.58 \mathrm{E}-03$ & $3.41 \mathrm{E}-03$ & \\
\hline U-bend & Liquid & 297 & $53 . \overline{7159}$ & 53.6329 & $0.0 \overline{7} 45$ & 54.7220 & $3.45 \mathrm{E}-03$ & & \\
\hline U-bend & Vapor & 298 & 55.6669 & 55.5956 & 0.0628 & 56.5792 & $2.81 \mathrm{E}-03$ & & \\
\hline U-bend & Vapor & 299 & 55.7341 & 55.6635 & 0.0621 & 56.6431 & $2.78 \mathrm{E}-03$ & 2.93E-03 & \\
\hline U-bend & Vapor & 300 & 55.4482 & 55.3682 & 0.0715 & 56.3710 & $3.21 \mathrm{E}-\overline{03}$ & & \\
\hline
\end{tabular}


TABLE, XLS

\begin{tabular}{|c|c|c|c|c|c|c|c|c|c|}
\hline & & & Soln \#13 & & & & & & \\
\hline Type & Location & Spec ID\# & Starting & Post Wt & Wt. Loss & Specimen & Corr Rate & Aver Corr & \\
\hline & & & Wt., g & $g$ & & Area, $\mathrm{cm} 2$ & $\mathrm{~mm} / \mathrm{y}$ & Rate, $\mathrm{mm} / \mathrm{y}$ & \\
\hline Corrosion & Liquid & 422 & 30.7559 & 30.7522 & 0.0022 & 30.6350 & $1.82 \mathrm{E}-04$ & & \\
\hline Corrosion & Liquid & 423 & 31.0759 & 31.0716 & 0.0028 & 30.6808 & $2.31 \mathrm{E}-04$ & $1.98 \mathrm{E}-04$ & \\
\hline Corrosion & Liquid & 424 & 30.8218 & 30.8181 & 0.0022 & 30.6616 & $1.82 \mathrm{E}-04$ & & \\
\hline Corrosion & Vapor & 425 & 30.4357 & 30.4265 & 0.0077 & 30.6031 & $6.37 \mathrm{E}-04$ & & \\
\hline Corrosion & Vapor & 426 & 30.2006 & 30.1902 & 0.0089 & 30.5172 & $7.38 \mathrm{E}-04$ & $6.76 \mathrm{E}-04$ & \\
\hline Corrosion & Vapor & 427 & 30.6881 & 30.6787 & 0.0079 & 30.6678 & $6.52 \mathrm{E}-04$ & & \\
\hline U-bend & Liquid & 277 & 55.4890 & 55.4788 & 0.0017 & 56.4098 & $7.63 \mathrm{E}-05$ & & \\
\hline U-bend & Liquid & 278 & 55.5376 & 55.5318 & -0.0027 & 56.4561 & $-1.21 \mathrm{E}-04$ & $2.18 \mathrm{E}-07$ & \\
\hline U-bend & Liquid & 279 & 54.7657 & 54.7562 & 0.0010 & 55.7213 & $4.54 \mathrm{E}-05$ & & \\
\hline U-bend & Vapor & 280 & 56.4640 & 56.4474 & 0.0081 & 57.3379 & $3.58 \mathrm{E}-04$ & & \\
\hline U-bend & Vapor & 281 & 56.2871 & 56.2702 & 0.0084 & 57.1695 & $3.72 \mathrm{E}-04$ & $3.31 E-04$ & \\
\hline U-bend & Vapor & 282 & 55.0517 & 55.0374 & 0.0058 & 55.9936 & $2.62 \bar{E}-04$ & & \\
\hline & & & Soln \#14 & & & & & & \\
\hline Type & Location & Spec ID\# & Starting & Post Wt & Wt. Loss & Specimen & Corr Rate & Aver Corr & \\
\hline & & & Wt., g & $\mathrm{g}$ & & Area, $\mathrm{cm} 2$ & $\mathrm{~mm} / \mathrm{y}$ & Rate, $\mathrm{mm} / \mathrm{v}$ & \\
\hline Corrosion & Liquid & 428 & 30.5013 & 30.4681 & 0.0317 & 30.5873 & $2.62 \mathrm{E}-03$ & & \\
\hline Corrosion & Liquid & 429 & 30.7708 & 30.7381 & 0.0312 & 30.6576 & $2.58 \mathrm{E}-03$ & $2.61 \mathrm{E}-03$ & \\
\hline Corrosion & Liquid & 430 & 29.2987 & 29.2655 & 0.0317 & 30.3537 & $2.64 \mathrm{E}-03$ & & \\
\hline Corrosion & Vapor & 431 & 31.0518 & 31.0067 & 0.0436 & 30.6999 & $3.60 \mathrm{E}-03$ & & \\
\hline Corrosion & Vapor & 432 & 30.8186 & 30.7733 & 0.0438 & 30.6420 & $3.62 \mathrm{E}-03$ & $3.58 \mathrm{E}-03$ & \\
\hline Corrosion & Vapor & 433 & 30.6478 & 30.6035 & 0.0428 & 30.6233 & $3.54 \mathrm{E}-03$ & & \\
\hline U-bend & Liquid & 283 & 55.0167 & 54.9542 & 0.0540 & 55.9603 & $2.44 \mathrm{E}-03$ & & \\
\hline U-bend & Liquid & 284 & 55.2280 & 55.1677 & 0.0518 & 56.1614 & $2.33 \mathrm{E}-03$ & $2.36 \mathrm{E}-03$ & \\
\hline U-bend & Liquid & 285 & 55.6568 & 55.5971 & 0.0512 & 56.5696 & $2.29 \mathrm{E}-03$ & & \\
\hline U-bend & Vapor & 286 & 55.5717 & 55.4899 & 0.0733 & 56.4886 & $3.28 \mathrm{E}-03$ & & \\
\hline U-bend & Vapor & 287 & 55.4961 & 55.4177 & 0.0699 & 56.4166 & $3.14 \mathrm{E}-03$ & $3.21 \mathrm{E}-03$ & \\
\hline U-bend & Vapor & $28 \overline{8}$ & 55.8673 & 55.7870 & 0.0718 & 56.7699 & $3.20 \mathrm{E}-\mathrm{O} 3$ & & \\
\hline
\end{tabular}


TABLE.XLS

\begin{tabular}{|c|c|c|c|c|c|c|c|c|c|}
\hline & & & Soln \#11 & & & & & & \\
\hline \multirow[t]{2}{*}{ Type } & Location & Spec ID\# & Starting & Post $\mathrm{Wt}$ & Wt. Loss & Specimen & Corr Rate & Aver Corr & \\
\hline & & & Wt., g & $g$ & & Area, $\mathrm{cm} 2$ & $\mathrm{~mm} / \mathrm{y}$ & Rate, $\mathrm{mm} / \mathrm{y}$ & \\
\hline Corrosion & Liquid & 410 & 30.2164 & 30.2140 & 0.0009 & 30.5595 & $7.46 \mathrm{E}-05$ & & \\
\hline Corrosion & Liquid & 411 & 30.5793 & 30.5792 & -0.0014 & 30.6471 & $-1.16 \mathrm{E}-04$ & $1.12 \mathrm{E}-05$ & \\
\hline Corrosion & Liquid & 412 & 30.3008 & 30.2984 & 0.0009 & 30.4822 & $7.47 \mathrm{E}-05$ & & \\
\hline Corrosion & Vapor & 413 & 30.3237 & 30.3202 & 0.0020 & 30.5661 & $1.66 \mathrm{E}-04$ & & \\
\hline Corrosion & Vapor & 414 & 30.5228 & 30.5197 & 0.0016 & 30.7346 & $1.32 \mathrm{E}-04$ & $1.38 \mathrm{E}-04$ & \\
\hline Corrosion & Vapor & 415 & 30.4647 & 30.4618 & 0.0014 & 30.5620 & $1.16 \mathrm{E}-\mathrm{O} 4$ & & \\
\hline U-bend & Liquid & 265 & 55.2704 & 55.2654 & -0.0035 & 56.2018 & $-1.58 E-04$ & & \\
\hline U-bend & Liquid & 266 & 55.3297 & 55.3265 & -0.0053 & 56.2582 & $-2.38 \mathrm{E}-04$ & $-1.95 \mathrm{E}-04$ & \\
\hline U-bend & Liquid & 267 & 55.1375 & 55.1332 & -0.0042 & 56.0753 & $-1.90 E-04$ & & \\
\hline U-bend & Vapor & 268 & 54.7167 & 54.7093 & -0.0011 & 55.6747 & $-5.00 \mathrm{E}-05$ & & \\
\hline U-bend & Vapor & 269 & 54.7071 & 54.6906 & 0.0080 & 55.6656 & $3.64 \mathrm{E}-04$ & $1.99 \overline{\mathrm{E}-04}$ & \\
\hline \multirow[t]{2}{*}{ U-bend } & Vapor & 270 & 55.3870 & 55.3722 & 0.0063 & 56.3127 & 2.83E-04 & & \\
\hline & & & Soln \#12 & & & & & & \\
\hline \multirow[t]{2}{*}{ Type } & Location & Spec ID\# & Starting & Post Wt & Wt. Loss & Specimen & Corr Rate & Aver Corr & \\
\hline & & & Wt., g & $g$ & & Area, $\mathrm{cm} 2$ & $\mathrm{~mm} / \mathrm{y}$ & Rate, $\mathrm{mm} / \mathrm{y}$ & \\
\hline Corrosion & Liquid & 416 & 30.4892 & $30 . \overline{4656}$ & 0.0221 & 30.5261 & $1.83 \mathrm{E}-03$ & & \\
\hline Corrosion & Liquid & 417 & 30.6258 & 30.6038 & 0.0205 & 30.6276 & $1.69 \mathrm{E}-03$ & $1.65 \mathrm{E}-03$ & \\
\hline Corrosion & Liquid & 418 & 30.2612 & 30.2424 & 0.0173 & 30.6200 & $1.43 \mathrm{E}-03$ & & \\
\hline Corrosion & Vapor & 419 & 30.6865 & 30.6460 & 0.0390 & 30.6162 & 3.22E-03 & & \\
\hline Corrosion & Vapor & 420 & 30.8938 & 30.8528 & 0.0395 & 30.7249 & $3.25 \mathrm{E}-03$ & $3.25 \mathrm{E}-03$ & \\
\hline Corrosion & Vapor & 421 & 30.6928 & 30.6517 & 0.0396 & 30.6989 & $3.27 \mathrm{E}-03$ & & \\
\hline U-bend & Liquid & 271 & 54.0163 & 53.9758 & 0.0320 & 55.0080 & $1.47 \mathrm{E}-03$ & & \\
\hline U-bend & Liquid & 272 & 55.8406 & 55.8018 & 0.0303 & 56.7445 & $1.35 \mathrm{E}-03$ & $1.44 \mathrm{E}-03$ & \\
\hline U-bend & Liquid & 273 & 55.9816 & 55.9392 & 0.0339 & 56.8787 & $1.51 \mathrm{E}-03$ & & \\
\hline U-bend & Vapor & 274 & 55.5007 & 55.4257 & 0.0665 & 56.4210 & $2.98 \mathrm{E}-03$ & & \\
\hline U-bend & Vapor & 275 & 56.3753 & 56.3116 & 0.0552 & 57.2535 & $2.44 \mathrm{E}-03$ & $2.73 \mathrm{E}-03$ & \\
\hline U-bend & Vapor & 276 & 55.8542 & 55.7836 & 0.0621 & 56.7575 & $2.77 \mathrm{E}-03$ & & \\
\hline
\end{tabular}




\begin{tabular}{|c|c|c|c|c|c|c|c|c|c|}
\hline & & & Soln \#9 & & & & & & \\
\hline \multirow[t]{2}{*}{ Type } & Location & Spec ID\# & Starting & Post Wt & Wt. Loss & Specimen & Corr Rate & Aver Corr & \\
\hline & & & Wt., g & 9 & & Area, $\mathrm{cm} 2$ & $\mathrm{~mm} / \mathrm{y}$ & Rate, $\mathrm{mm} / \mathrm{y}$ & \\
\hline Corrosion & Liquid & 398 & 30.5774 & 30.5735 & 0.0024 & 30.5491 & 1.99E-04 & & \\
\hline Corrosion & Liquid & 399 & 29.2529 & 29.2482 & 0.0032 & 30.2303 & 2.68E-04 & 2.19E-04 & \\
\hline Corrosion & Liquid & 400 & 30.9877 & 30.9839 & $0 . \overline{0023}$ & 30.5421 & 1.91E-04 & & \\
\hline Corrosion & Vapor & 401 & 30.9160 & 30.9082 & 0.0063 & 30.5775 & $5.22 \mathrm{E}-04$ & & \\
\hline Corrosion & Vapor & 402 & 30.8359 & 30.8256 & 0.0088 & 30.5922 & $7.28 \mathrm{E}-04$ & $5.67 \mathrm{E}-04$ & \\
\hline Corrosion & Vapor & 403 & 30.8164 & 30.8094 & 0.0055 & 30.7740 & $4.52 \mathrm{E}-04$ & & \\
\hline U-bend & Liquid & 253 & 54.8698 & 54.8569 & 0.0044 & 55.8204 & $2.00 \mathrm{E}-04$ & & \\
\hline U-bend & Liquid & 254 & 55.1661 & 55.1567 & 0.0009 & 56.1025 & $4.06 \mathrm{E}-05$ & $8.61 \mathrm{E}-05$ & \\
\hline U-bend & Liquid & 255 & 55.0807 & 55.0718 & 0.0004 & 56.0212 & $1.81 \mathrm{E}-05$ & & \\
\hline U-bend & Vapor & 256 & 54.9793 & 54.9672 & 0.0036 & 55.9247 & $1.63 \mathrm{E}-04$ & & \\
\hline U-bend & Vapor & 257 & $55.17 \overline{52}$ & 55.1588 & 0.0079 & 56.1111 & $3.56 \mathrm{E}-04$ & $3.10 \mathrm{E}-04$ & \\
\hline \multirow[t]{2}{*}{ ü-bend } & Vapor & 258 & 55.1760 & 55.1584 & 0.0091 & 56.1119 & $4.11 \mathrm{E}-04$ & & \\
\hline & & & Soln \#10 & & & & & & \\
\hline Type & Location & Spec ID\# & Starting & Post Wt & Wt. Loss & Specimen & Corr Rate & Aver Corr & \\
\hline & & & Wt., g & $\mathrm{g}$ & & Area, $\mathrm{cm} 2$ & $\mathrm{~mm} / \mathrm{y}$ & Rate, $\mathrm{mm} / \mathrm{y}$ & \\
\hline Corrosion & Liquid & 404 & 30.2213 & 30.1367 & 0.0831 & 30.4078 & $6.92 \mathrm{E}-03$ & & \\
\hline Corrosion & Liquid & 405 & 29.7655 & 29.6789 & 0.0851 & 30.2776 & $7.12 \mathrm{E}-03$ & $7.73 \mathrm{E}-03$ & \\
\hline Corrosion & Liquid & 406 & 30.6524 & 30.5404 & 0.1105 & 30.5078 & $9.17 E-03$ & & \\
\hline Corrosion & Vapor & 407 & 30.7620 & 30.6753 & 0.0852 & 30.6797 & 7.03E-03 & & \\
\hline Corrosion & Vapor & 408 & 30.4286 & 30.2928 & 0.1343 & 30.5063 & $1.11 \mathrm{E}-02$ & $8.35 \mathrm{E}-03$ & \\
\hline Corrosion & Vapor & 409 & 30.3976 & 30.3131 & 0.0830 & 30.5950 & $6.87 \mathrm{E}-03$ & & \\
\hline U-bend & Liquid & 259 & 55.3036 & 54.8257 & 0.4694 & 56.2334 & $2.11 \mathrm{E}-02$ & & \\
\hline U-bend & Liquid & 260 & 55.8825 & 55.7028 & 0.1712 & 56.7844 & $7.63 \mathrm{E}-03$ & $1.27 \mathrm{E}-02$ & \\
\hline U-bend & Liquid & 261 & 54.8422 & 54.6255 & 0.2082 & 55.7942 & $9.45 \mathrm{E}-03$ & & \\
\hline U-bend & Vapor & 262 & 54.7897 & 54.6128 & 0.1684 & 55.7442 & $7.65 \mathrm{E} \cdot 03$ & & \\
\hline U-bend & Vapor & 263 & 55.3677 & 55.2181 & 0.1411 & 56.2944 & $6.35 \mathrm{E}-03$ & $6.98 \mathrm{E}-03$ & \\
\hline U-bend & Vapor & 264 & 55.6609 & 55.4969 & 0.1555 & 56.5735 & $6.96 \mathrm{E}-03$ & & \\
\hline
\end{tabular}


TABLE.XLS

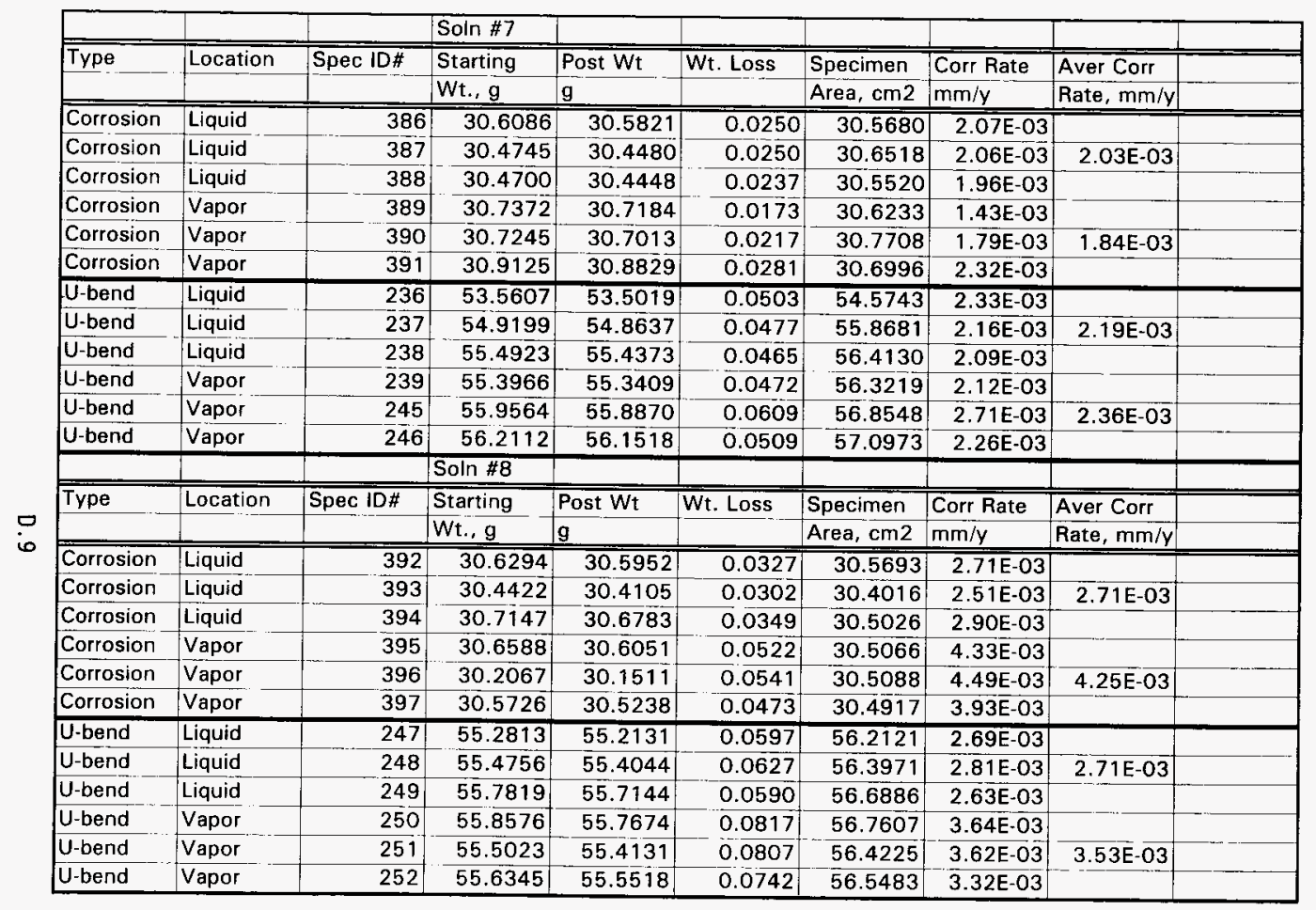


TABLE,XLS

\begin{tabular}{|c|c|c|c|c|c|c|c|c|c|}
\hline & & & Soln \#5 & & & & & & \\
\hline \multirow[t]{2}{*}{ Type } & Location & Spec ID\# & Starting & Post Wt & Wt. Loss & Specimen & Corr Rate & Aver Corr & \\
\hline & & & Wt., g & $\mathrm{g}$ & & Area, cm2 & $\mathrm{mm} / \mathrm{y}$ & Rate, $\mathrm{mm} / \mathrm{y}$ & \\
\hline Corrosion & Liquid & 374 & 30.1389 & 30.1090 & 0.0284 & $30 . \overline{3779}$ & $2.37 \mathrm{E}-03$ & & \\
\hline Corrosion & Liquid & 375 & 30.3551 & 30.3263 & 0.0273 & 30.4862 & $2.27 \mathrm{E}-03$ & $2.21 \mathrm{E}-03$ & \\
\hline Corrosion & Liquid & 376 & 30.2543 & 30.2289 & 0.0239 & 30.4443 & $1.99 \mathrm{E}-03$ & & \\
\hline Corrosion & Vapor & 377 & 30.5470 & 30.5206 & $\overline{0.0249}$ & 30.5705 & $2.06 \mathrm{E}-03$ & & \\
\hline Corrosion & Vapor & 378 & 30.2843 & 30.2493 & 0.0335 & 30.4207 & $2.79 \bar{E}-03$ & $2.20 \mathrm{E}-03$ & \\
\hline Corrosion & Vapor & 379 & 30.0047 & 29.9825 & 0.0207 & 30.1730 & $1.74 \mathrm{E}-03$ & & \\
\hline U-bend & Liquid & 224 & 54.6539 & 54.5677 & 0.0777 & 55.6149 & $3.54 \mathrm{E}-03$ & & \\
\hline U-bend & Liquid & 225 & 54.1479 & 54.0716 & 0.0678 & 55.1333 & $3.11 \mathrm{E}-03$ & $3.54 \mathrm{E}-03$ & \\
\hline U-bend & Liquid & 226 & 54.9554 & 54.8592 & 0.0877 & 55.9019 & $3.97 \mathrm{E}-03$ & & \\
\hline U-bend & Vapor & 227 & 53.5802 & 53.5148 & 0.0569 & 54.5929 & $2.64 \mathrm{E}-03$ & & \\
\hline U-bend & Vapor & 228 & 54.9481 & 54.8933 & $\overline{0.0463}$ & 55.8950 & $2.10 \mathrm{E}-03$ & $2.18 \mathrm{E}-03$ & \\
\hline \multirow[t]{2}{*}{ U-bend } & Vapor & 229 & 54.8020 & 54.7536 & 0.0399 & 55.7559 & $1.81 \mathrm{E}-03$ & & \\
\hline & & & Soln \#6 & & & & & & \\
\hline \multirow[t]{2}{*}{ Type } & Location & Spec ID\# & Starting & Post Wt & Wt. Loss & Specimen & Corr Rate & Aver Corr & \\
\hline & & & Wt., $\mathrm{g}$ & $\mathrm{g}$ & & Area, $\mathrm{cm} 2$ & $\mathrm{~mm} / \mathrm{y}$ & Rate, $\mathrm{mm} / \mathrm{y}$ & \\
\hline Corrosion & Liquid & 380 & 30.4051 & $30 . \overline{3852}$ & 0.0184 & 30.4379 & $1.53 \mathrm{E}-03$ & & \\
\hline Corrosion & Liquid & 381 & 30.4626 & 30.4384 & 0.0227 & 30.4510 & $1.89 \mathrm{E}-03$ & $1.63 \mathrm{E}-03$ & \\
\hline Corrosion & Liquid & 382 & 30.2885 & 30.2693 & 0.0177 & 30.4784 & 1.47E-03 & & \\
\hline Corrosion & Vapor & 383 & 30.6120 & 30.5984 & 0.0121 & 30.5605 & $1.00 \mathrm{E}-03$ & & \\
\hline Corrosion & Vapor & 384 & 30.5788 & 30.5676 & 0.0097 & 30.6202 & $8.02 \mathrm{E}-04$ & $8.94 \mathrm{E}-04$ & \\
\hline Corrosion & Vapor & 385 & 30.2530 & 30.2409 & 0.0106 & 30.5862 & $8.77 \mathrm{E}-04$ & & \\
\hline U-bend & Liquid & 230 & 54.3715 & 54.2941 & 0.0689 & 55.3461 & $3.15 \mathrm{E}-03$ & & \\
\hline U-bend & Liquid & 231 & 54.4233 & 54.3516 & 0.0632 & 55.3954 & $2.89 \mathrm{E}-03$ & $3.14 \mathrm{E}-03$ & \\
\hline U-bend & Liquid & 232 & 54.3692 & 54.2865 & 0.0742 & 55.3439 & $3.39 \mathrm{E}-03$ & & \\
\hline U-bend & Vapor & 233 & 53.9403 & 53.9077 & 0.0241 & 54.9357 & $1.11 \mathrm{E}-03$ & & \\
\hline U-bend & Vapor & 234 & 53,6792 & 53.6370 & 0.0337 & 54.6871 & $1.56 \mathrm{E}-03$ & $1.16 \mathrm{E}-03$ & \\
\hline U-bend & Vapor & 235 & 52.9751 & 52.9491 & 0.0175 & 54.0169 & $8.20 \mathrm{E}-04$ & & \\
\hline
\end{tabular}


TABLE. XLS

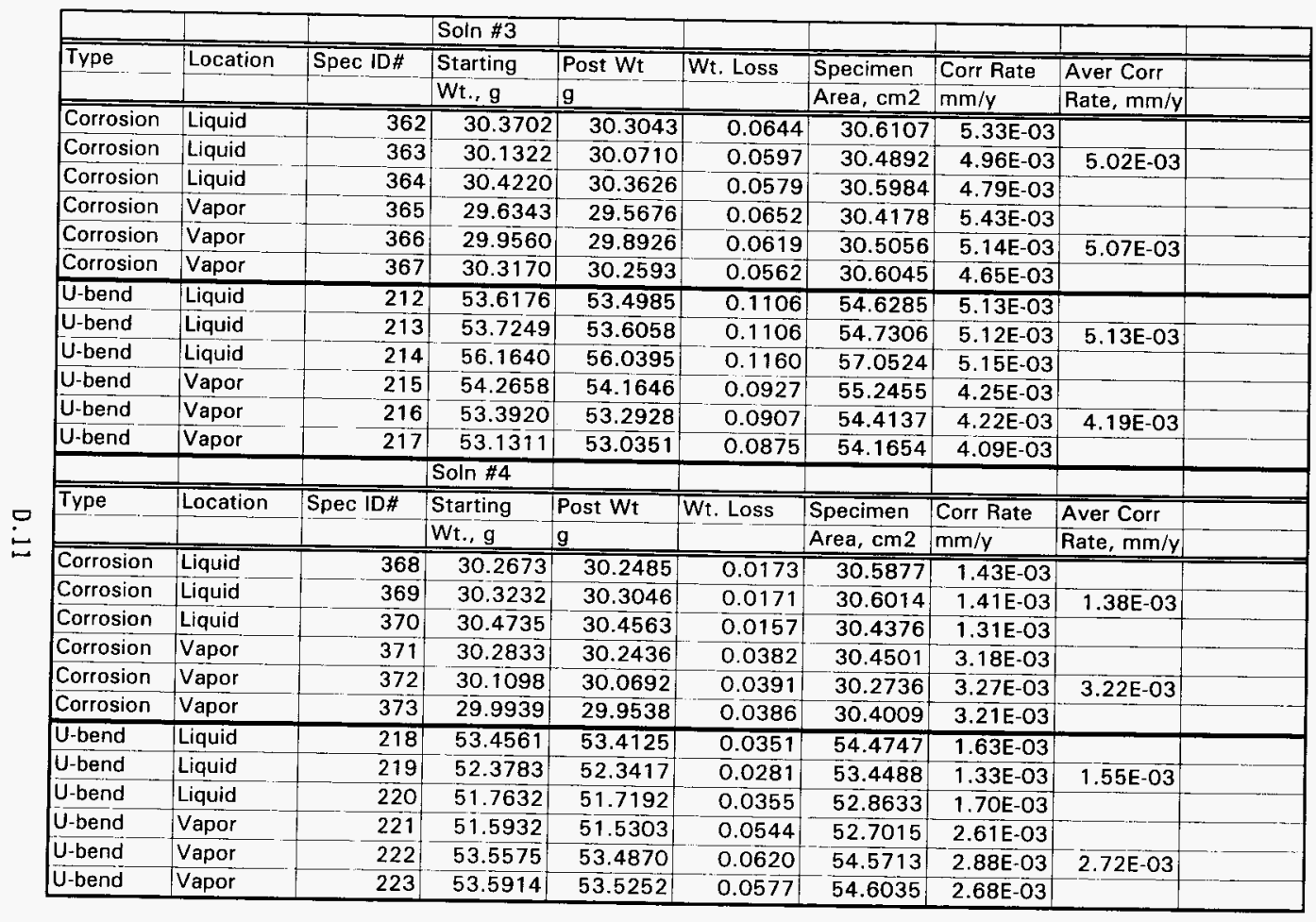


TABLE. XLS

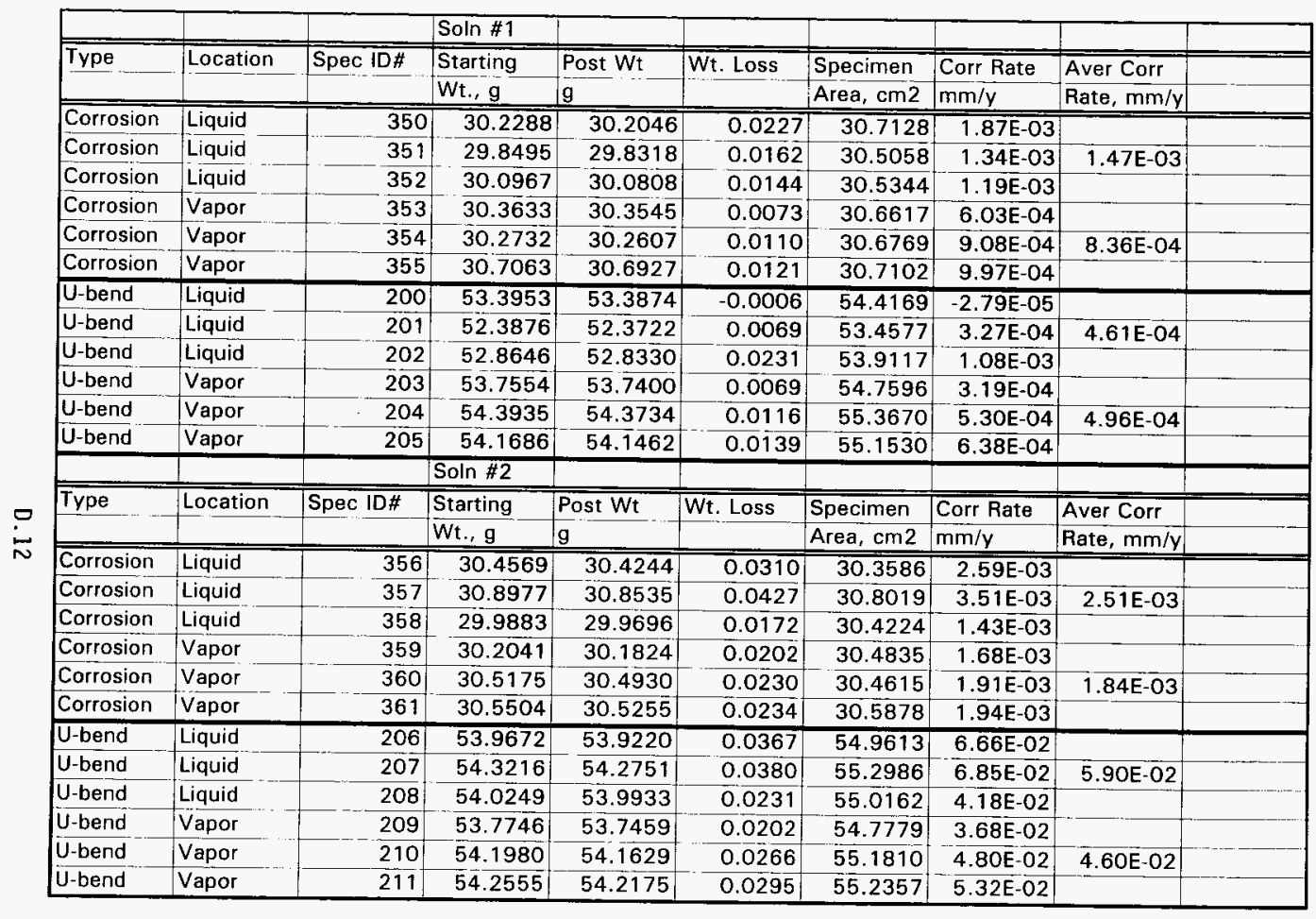


WHC-SD-WM-TI-765, Rev 0

APPENDIX E: OPTICAL PHOTOGRAPHS OF CLEANED SPECIMENS

E- $\mathbf{i}$ 


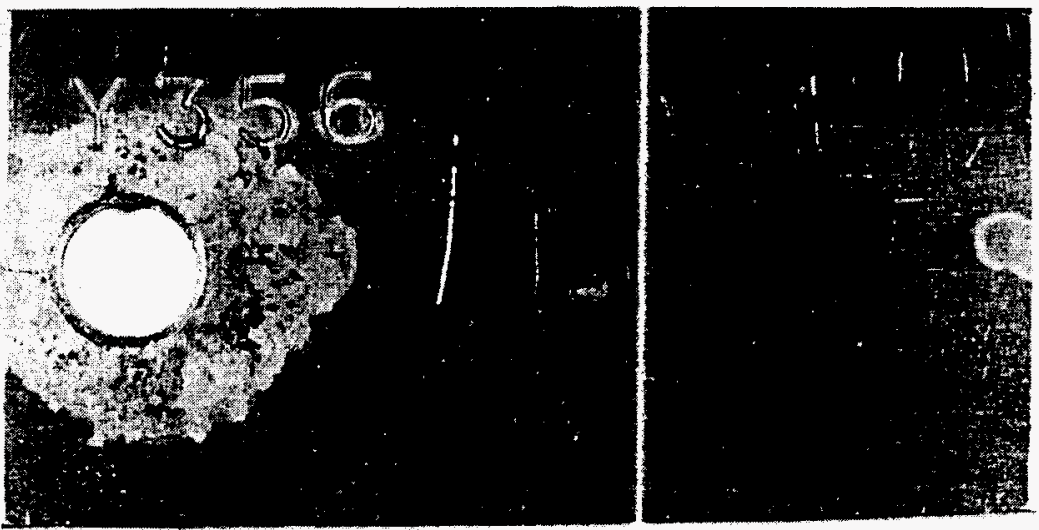

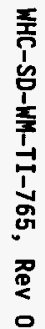

Figure E.1 Totally Immersed Weight Loss Specimen from Solution 2. Note crevice attack around hole. 


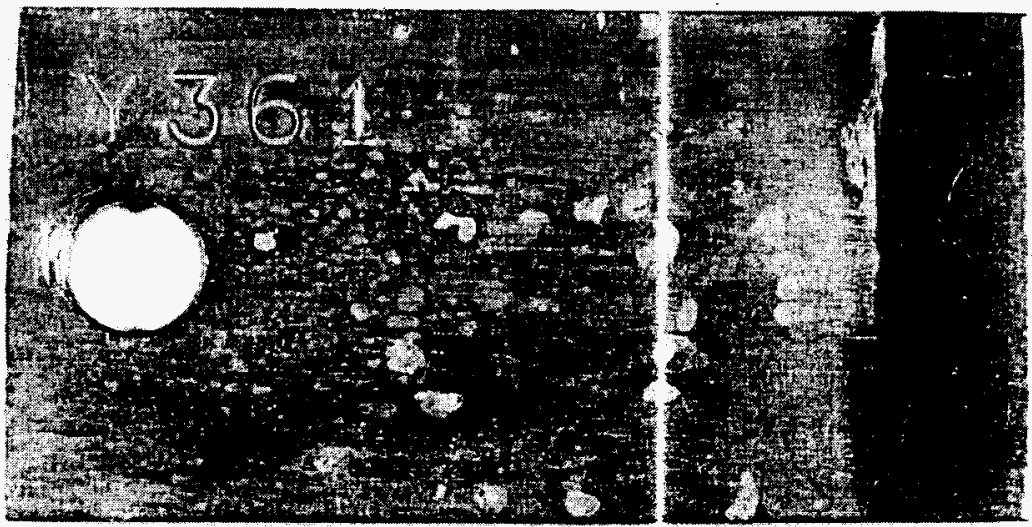

Figure E.2 Air/Solution Weight Loss Specimın from Solution 2. Note waterline attack and pits in the vapor phase. 
WHC-SD-WM-TI-765, Rev 0

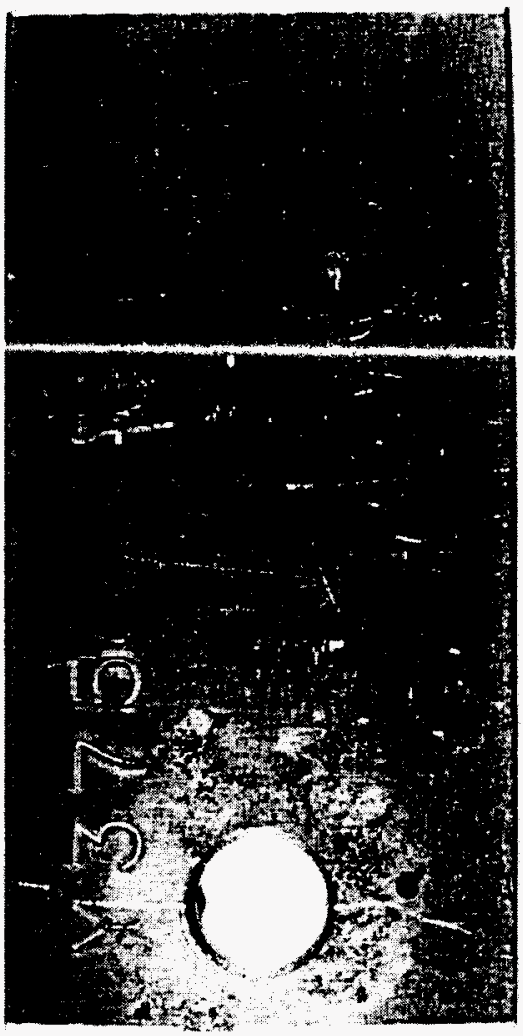

告

튼

ฏ

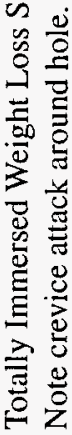

$m$

品

E.3 
WHC-SD-WM-TI-765, Rev 0

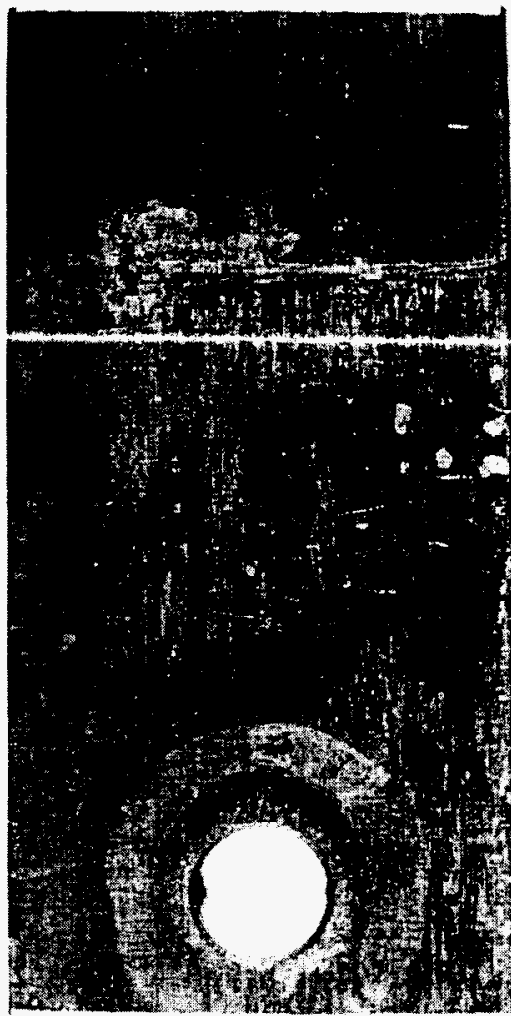

n

은

芯

क

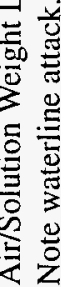

寸

[I

్ㅡㄹ 


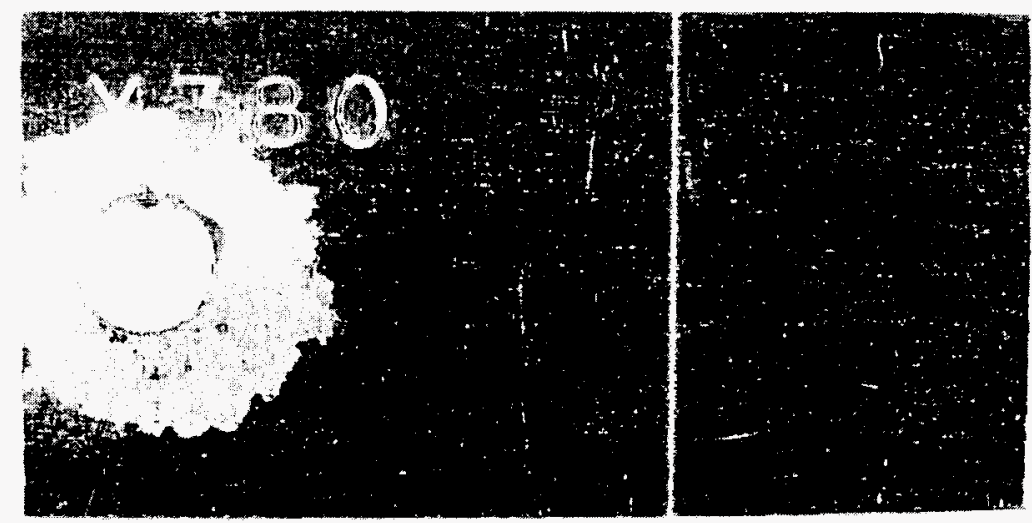

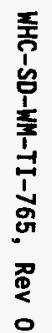

Figure E.5 Totally Immersed Weight Loss $S_{\text {p }}$ ecimen from Solution 6. Note crevice attack around hole. 
WHC-SD-WM-TI-765, Rev 0

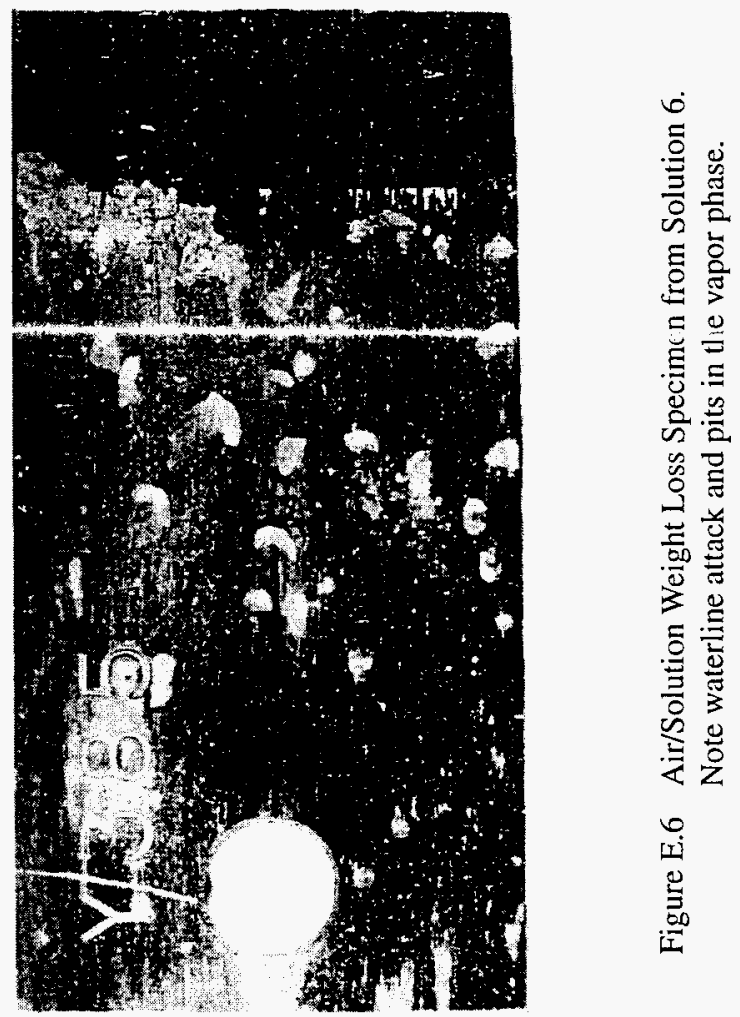


WHC-SD-WM-TI-765, Rev 0

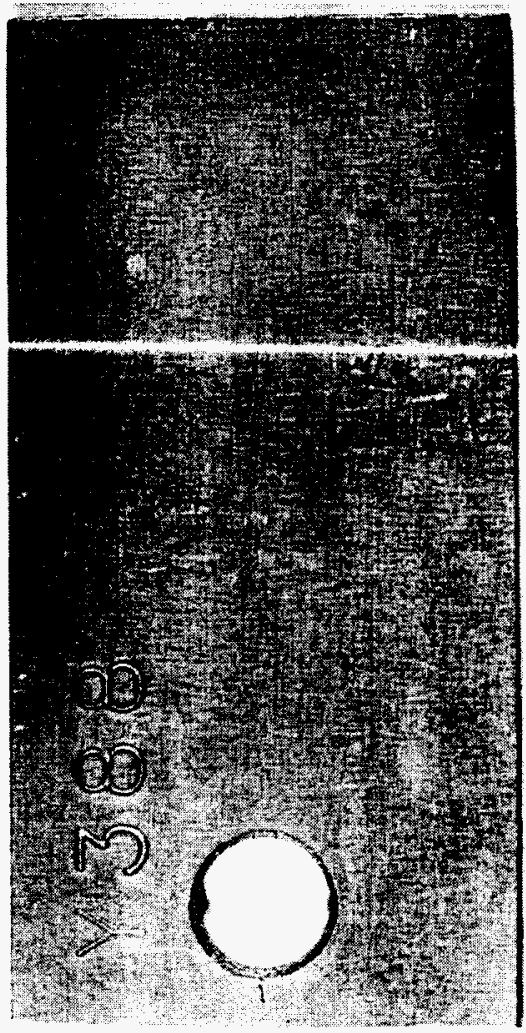

홀

을

离

के

告卷

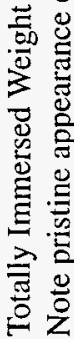

r

工I

$\underset{0}{0}$

E.7 


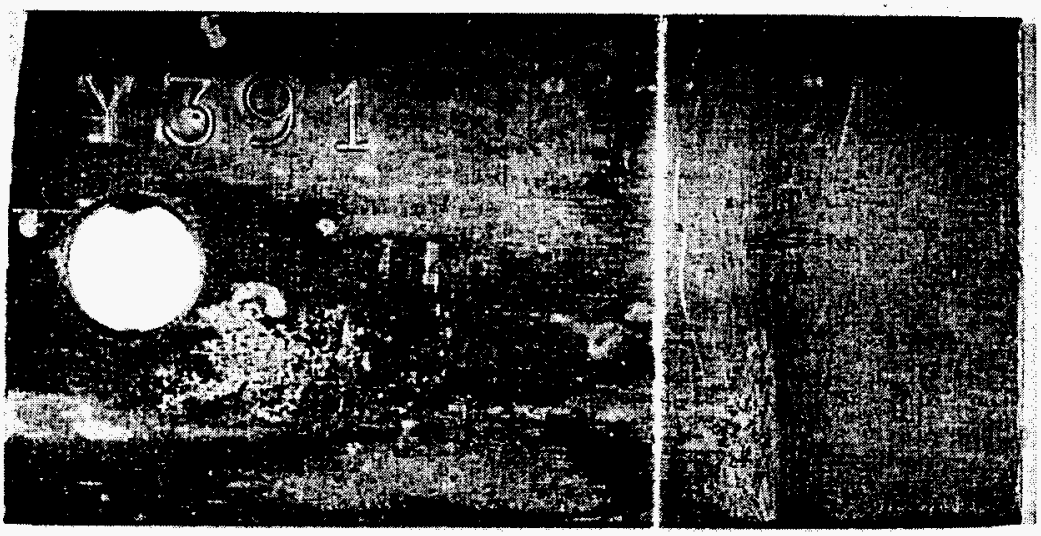

Figure E.8 Air/Solution Weight Loss Specinen from Solution 7. Note waterline attack and crevic 2 attack near hole. 


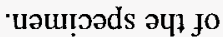

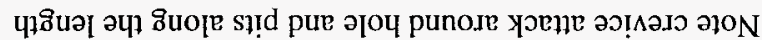

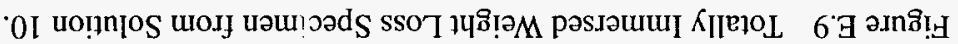

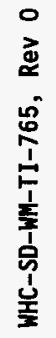

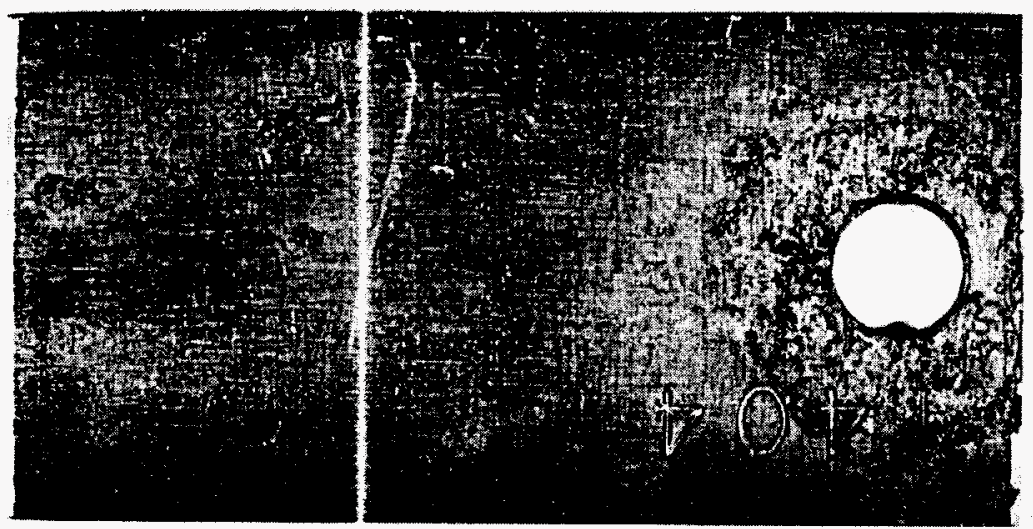




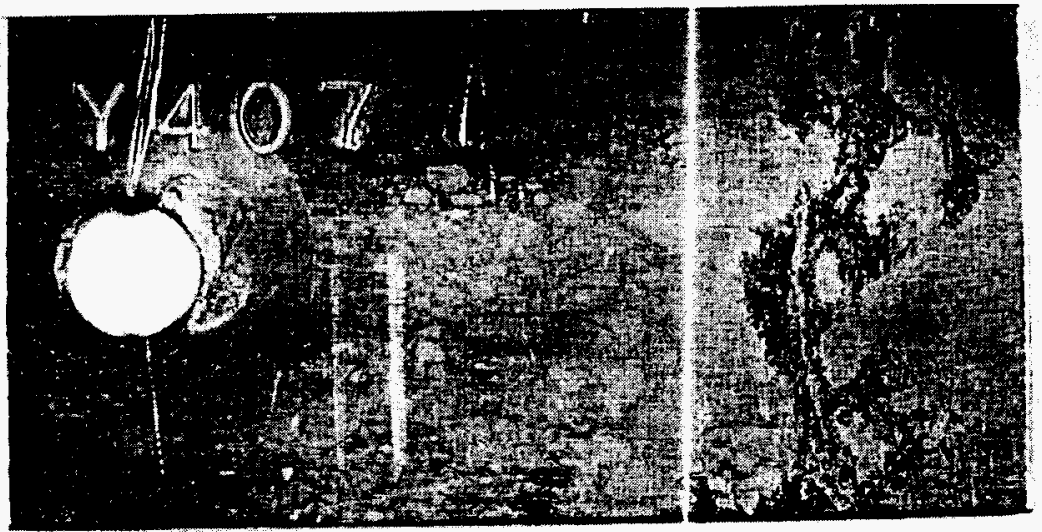

Figure E.10 Air/Solution Weight Loss Specim en from Solution 10. Note extensive waterline attack, $\mathrm{p}$ ts in the vapor space and slight crevice attack at hole. 


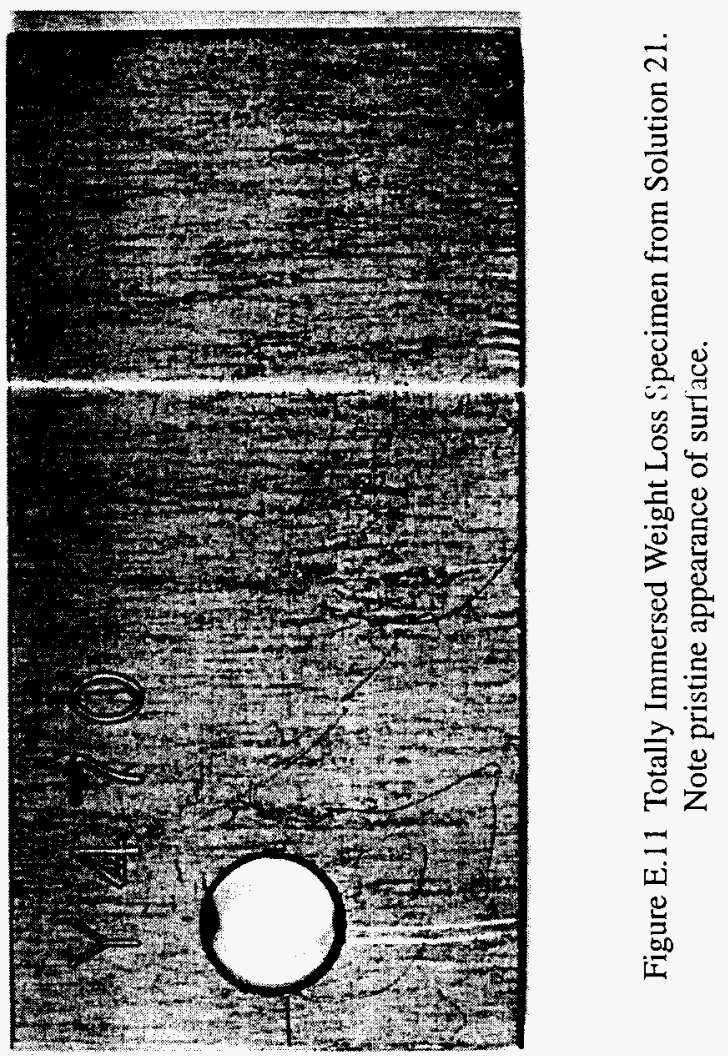

E.11 


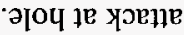

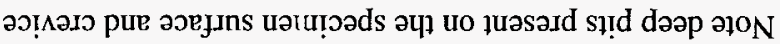

' $Z$ uo!̣n

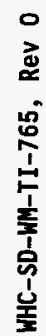
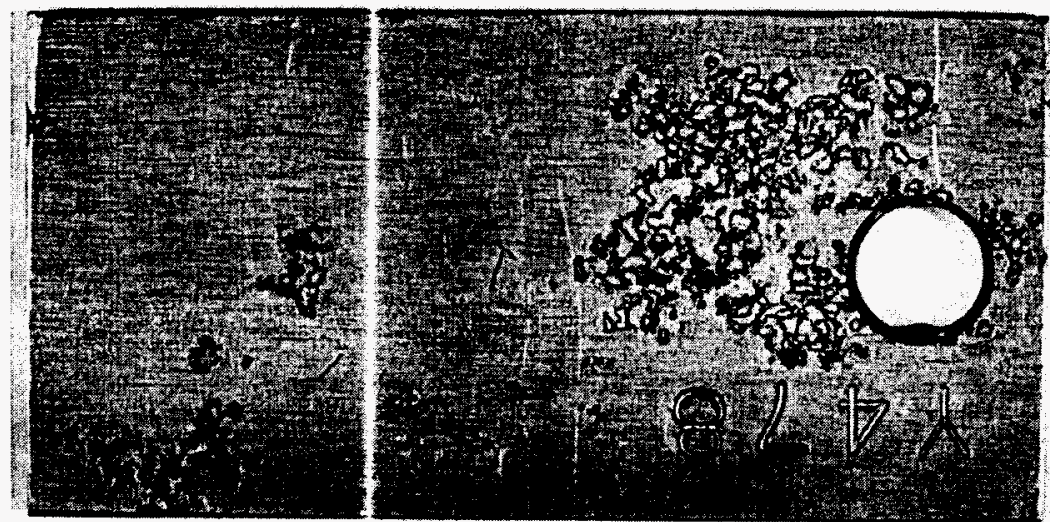

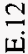




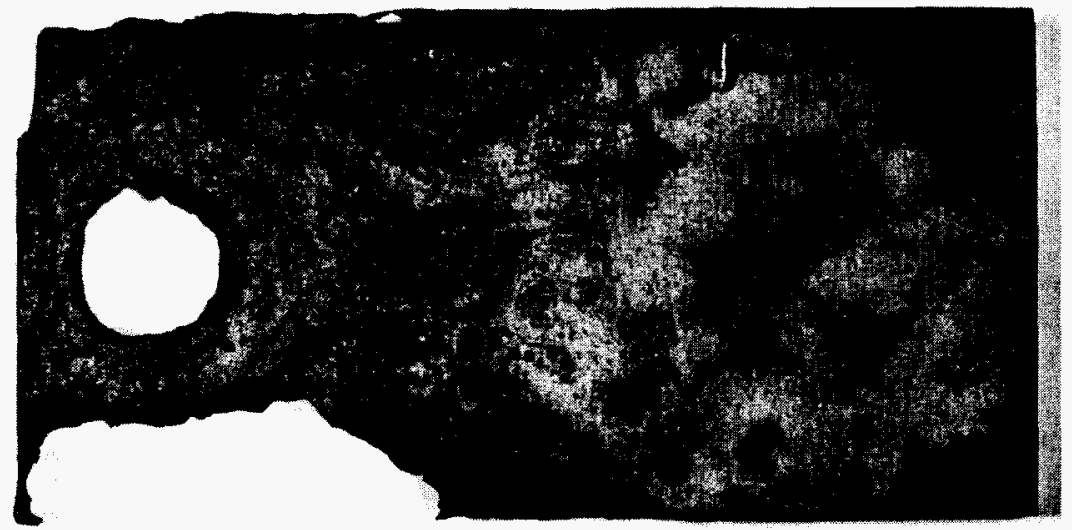

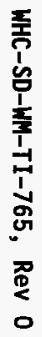

Figure E.13 Air/Solution Weight Loss Specimen from Solution 23. Note extensive removal of metal at and above the waterline due to massive waterline attack. 
WHC-SD-WM-TI-765, Rev 0

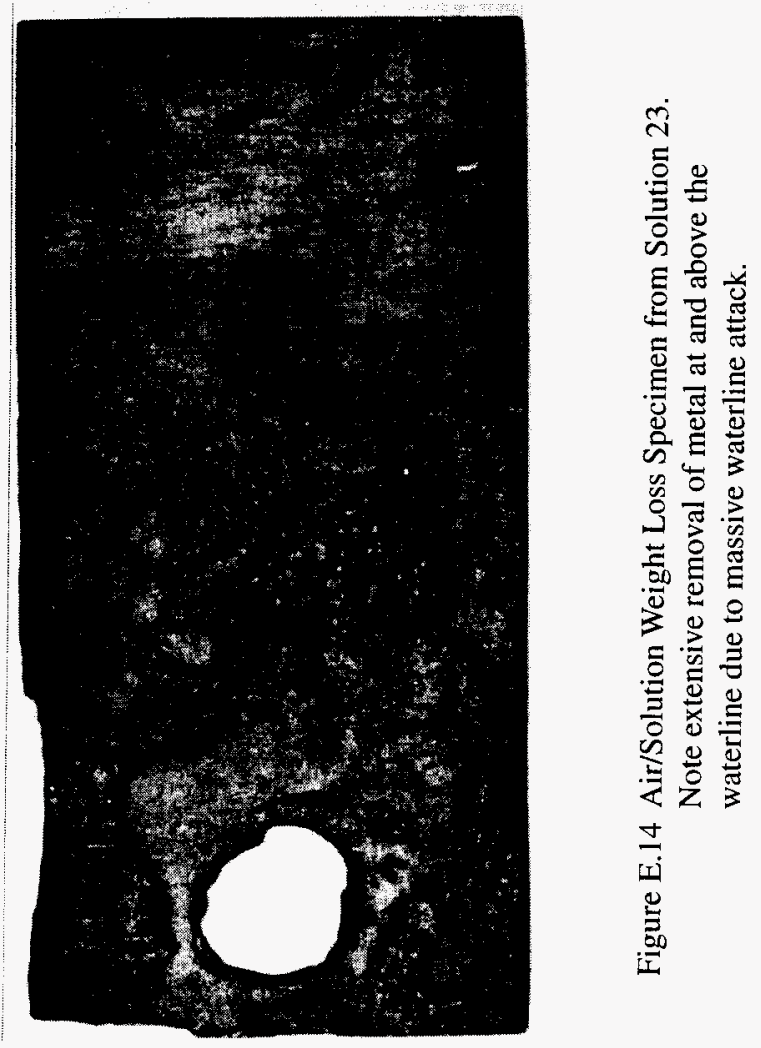

E. 14 


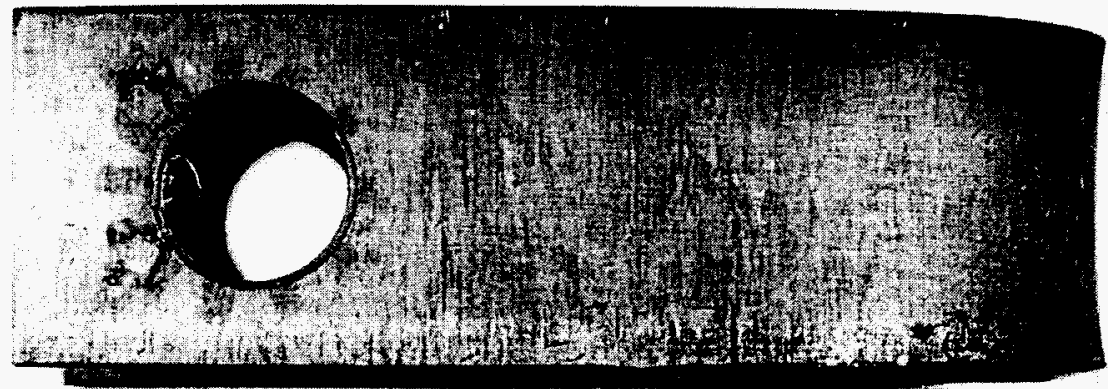

Figure E.15 Totally Immersed U-Bend Specimen from Solution 23.

Note small amount of crevice attack around hole. 


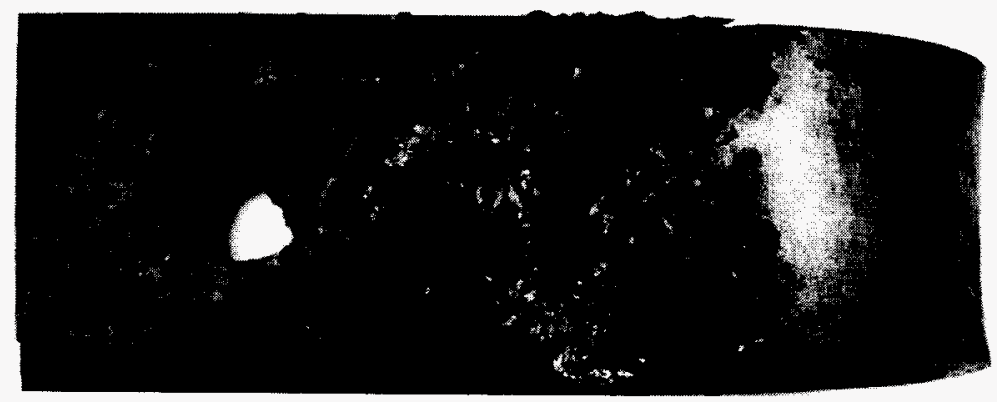

$\frac{\pi}{6}$

Figure E.16 Air/Solution U-Bend Specimen from Solution 23. Note extensive removal of metal at and above the waterline due to massive waterline attack. 


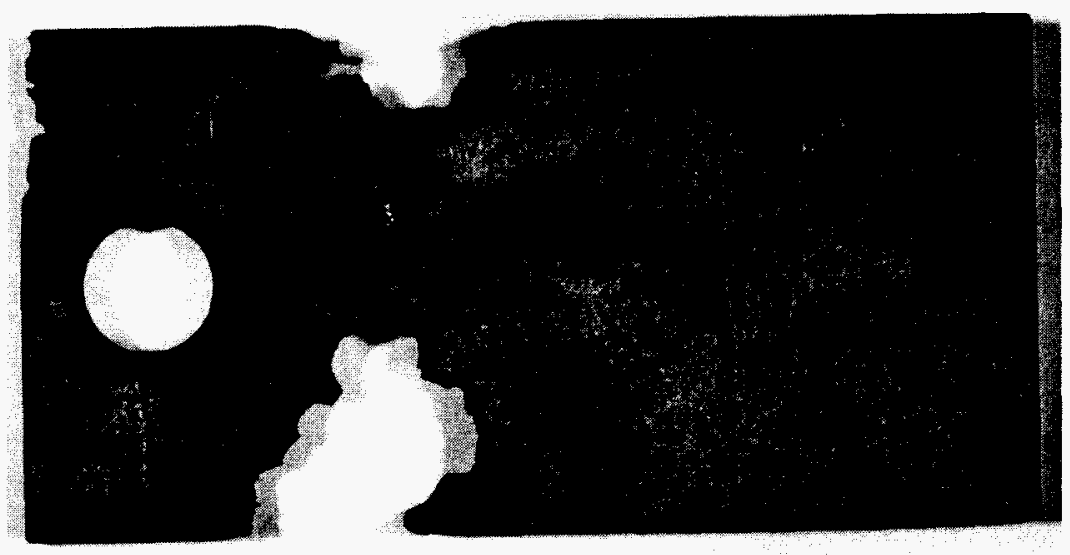

Figure E.17 Air/Solution Weight Loss Specimen from Solution 24.

Note extensive removal of metal at and above the waterline due to massive waterline attack. 


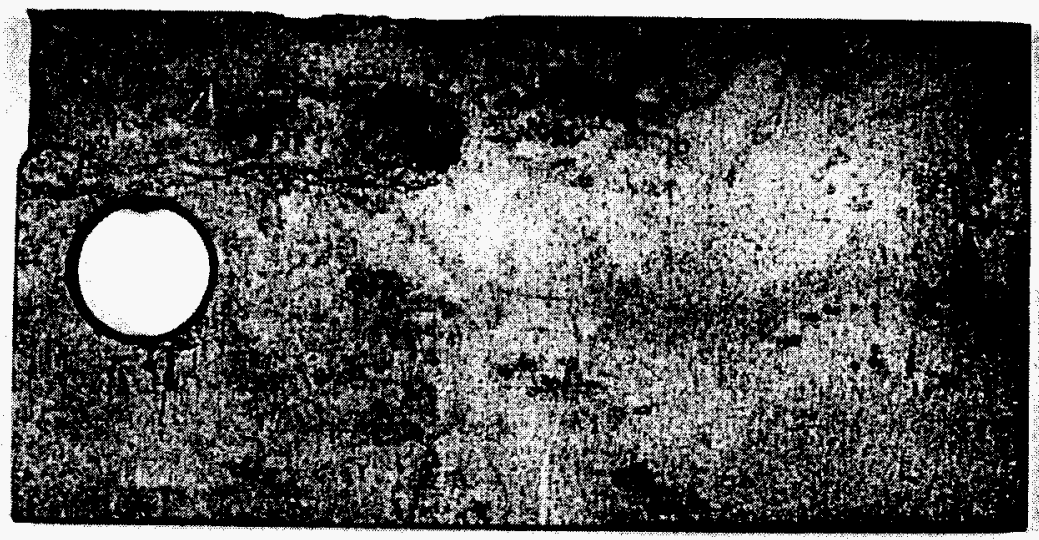

Figure E.18 Air/Solution Weight Loss Specimen from Solution 24. Note pronounced area of attack with metal removal in vapor phase. 
WHC-SD-WM-TI-765, Rev 0

APPENDIX F: OBSERVATIONS ON CLEANED SPECIMENS 
Observations on Cleaned Specimens:

Pitting (Density, Size, Maximum Depth), Crevice Attack (Maximum Depth), Waterline Attack (Maximum Depth)

Solution 1

\begin{tabular}{|c|c|}
\hline Immersed Specimens & $\begin{array}{l}\text { Pitting: incipient pits } \\
2.5 \mathrm{E} 3 / \mathrm{m}^{2},<0.5 \mathrm{~mm}^{2},<0.4 \mathrm{~mm}\end{array}$ \\
\hline $\begin{array}{l}\text { Air/Soln Interface } \\
\text { Specimens }\end{array}$ & $\begin{array}{l}\text { Pitting: } 1 E 4 / \mathrm{m}^{2}, 0.81 \mathrm{~mm}^{2},<0.4 \mathrm{~mm} \\
\text { Crevice Attack: } 0.14 \mathrm{~mm} \text { deep } \\
\text { Waterline attack: } 0.02 \mathrm{~mm} \text { deep }\end{array}$ \\
\hline
\end{tabular}

Solution 2

\begin{tabular}{||l|l|}
\hline Immersed Specimens & $\begin{array}{l}\text { Pitting: } 2.5 \mathrm{E} 3 / \mathrm{m}^{2},<0.5 \mathrm{~mm}^{2},<0.4 \mathrm{~mm} \\
\text { Heavy Crevice Attack: } 0.19 \mathrm{~mm} \text { deep }\end{array}$ \\
\hline $\begin{array}{l}\text { Air/Soln Interface } \\
\text { Specimens }\end{array}$ & $\begin{array}{l}\text { Pitting: } 1 \mathrm{E} 4 / \mathrm{m}^{2}, 0.81 \mathrm{~mm}^{2},<0.4 \mathrm{~mm} \\
\text { Moderate Crevice Attack: } 0.21 \mathrm{~mm} \text { deep } \\
\end{array}$ \\
\hline
\end{tabular}

Solution 3

\begin{tabular}{||l|l||}
\hline Immersed Specimens & $\begin{array}{l}\text { Pitting: none } \\
\text { Crevice Attack: none }\end{array}$ \\
\hline $\begin{array}{l}\text { Air/Soln Interface } \\
\text { Specimens }\end{array}$ & $\begin{array}{l}\text { Pitting: none } \\
\text { Crevice Attack: none, except incipient } \\
\text { crevice on one U-bend specimen }\end{array}$ \\
\hline
\end{tabular}


Solution 4

\begin{tabular}{||l|l||}
\hline Immersed Specimens & $\begin{array}{l}\text { Pitting: none } \\
\text { Crevice Attack: none, except incipient } \\
\text { crevice on one U-bend specimen }\end{array}$ \\
\hline $\begin{array}{l}\text { Air/Soln Interface } \\
\text { Specimens }\end{array}$ & $\begin{array}{l}\text { Pitting: } 2.5 \mathrm{E} 3 / \mathrm{m}^{2},<0.5 \mathrm{~mm}^{2},<0.4 \mathrm{~mm} \\
\text { Light Crevice Attack: } 0.04 \mathrm{~mm} \text { deep } \\
\text { Waterline attack: } 0.06 \mathrm{~mm} \text { deep }\end{array}$ \\
\hline
\end{tabular}

Solution 5

\begin{tabular}{||l|l||}
\hline Immersed Specimens & $\begin{array}{l}\text { Pitting: } 1 E 4 / \mathrm{m}^{2}, 2.48 \mathrm{~mm}^{2},<0.4 \mathrm{~mm} \\
\text { Heavy Crevice Attack: } 0.12 \mathrm{~mm} \text { deep }\end{array}$ \\
\hline $\begin{array}{l}\text { Air/Soln Interface } \\
\text { Specimens }\end{array}$ & $\begin{array}{l}\text { Pitting: } 1 E 4 / \mathrm{m}^{2},<0.5 \mathrm{~mm}^{2},<0.4 \mathrm{~mm} \\
\text { Moderate Crevice Attack: } 0.08 \mathrm{~mm} \text { deep } \\
\end{array}$ \\
\hline
\end{tabular}

Solution 6

\begin{tabular}{||l|l||}
\hline Immersed Specimens & $\begin{array}{l}\text { Pitting: } 1 \mathrm{E} 4 / \mathrm{m}^{2}-5 \mathrm{E} 4 / \mathrm{m}^{2}, 1.82 \mathrm{~mm}^{2},<0.4 \\
\mathrm{~mm}\end{array}$ \\
& Heavy Crevice Attack: $0.18 \mathrm{~mm}$ deep \\
\hline $\begin{array}{l}\text { Air/Soln Interface } \\
\text { Specimens }\end{array}$ & Pitting: $5 \mathrm{E} 4 / \mathrm{m}^{2}, 0.81 \mathrm{~mm}^{2},<0.4 \mathrm{~mm}$ \\
& Light Crevice Attack: $0.06 \mathrm{~mm}$ deep \\
& Waterline attack: $0.19 \mathrm{~mm}$ deep \\
\hline
\end{tabular}


Solution 7

\begin{tabular}{||l|l||}
\hline Immersed Specimens & $\begin{array}{l}\text { Pitting: } 2.5 \mathrm{E} 3 / \mathrm{m}^{2},<0.5 \mathrm{~mm}^{2},<0.4 \mathrm{~mm} \\
\text { Light Crevice Attack: } 0.09 \mathrm{~mm} \text { deep }\end{array}$ \\
\hline $\begin{array}{l}\text { Air/Soln Interface } \\
\text { Specimens }\end{array}$ & $\begin{array}{l}\text { Pitting: } 5 \mathrm{E} 4 / \mathrm{m}^{2},<0.5 \mathrm{~mm}^{2},<0.4 \mathrm{~mm} \\
\text { Crevice Attack: } 0.14 \mathrm{~mm} \text { deep }\end{array}$ \\
& Waterline attack: $0.05 \mathrm{~mm}$ deep \\
\hline
\end{tabular}

Solution 8

\begin{tabular}{||l|l||}
\hline Immersed Specimens & $\begin{array}{l}\text { Pitting: none } \\
\text { Crevice Attack: none }\end{array}$ \\
\hline $\begin{array}{l}\text { Air/Soln Interface } \\
\text { Specimens }\end{array}$ & $\begin{array}{l}\text { Pitting: none } \\
\text { Crevice Attack: none }\end{array}$ \\
\hline
\end{tabular}

Solution 9

\begin{tabular}{|l|l||}
\hline Immersed Specimens & $\begin{array}{l}\text { Pitting: } 2.5 \mathrm{E} 3 / \mathrm{m}^{2},<0.5 \mathrm{~mm}^{2},<0.4 \mathrm{~mm} \\
\text { Light Crevice Attack: } 0.15 \mathrm{~mm} \text { deep }\end{array}$ \\
\hline $\begin{array}{l}\text { Air/Soln Interface } \\
\text { Specimens }\end{array}$ & $\begin{array}{l}\text { Pitting: } 1 \mathrm{E} 4 / \mathrm{m}^{2},<0.5 \mathrm{~mm}^{2},<0.4 \mathrm{~mm} \\
\text { Light Crevice Attack: } 0.05 \mathrm{~mm} \text { deep } \\
\text { Waterline attack: } 0.02 \mathrm{~mm} \text { deep }\end{array}$ \\
\hline
\end{tabular}

F. 3 
Solution 10

\begin{tabular}{||l|l||}
\hline \hline \multirow{2}{*}{$\begin{array}{l}\text { Immersed Specimens } \\
\text { Air/Soln Interface } \\
\text { Specimens }\end{array}$} & $\begin{array}{l}\text { Pitting: } 1 \mathrm{E} 4 / \mathrm{m}^{2}, 50.11 \mathrm{~mm}^{2},<0.4 \mathrm{~mm} \\
\text { Heavy Crevice Attack: } 0.16 \mathrm{~mm} \text { deep }\end{array}$ \\
& $\begin{array}{l}\text { Light Crevice Attack: } 0.09 \mathrm{~mm} \text { deep } \\
\text { Waterline attack: } 0.21 \mathrm{~mm} \text { deep }\end{array}$ \\
\hline
\end{tabular}

Solution 11

\begin{tabular}{||l|l|}
\hline Immersed Specimens & $\begin{array}{l}\text { Pitting: None } \\
\text { Light Crevice Attack: } 0.06 \mathrm{~mm} \text { deep }\end{array}$ \\
\hline $\begin{array}{l}\text { Air/Soln Interface } \\
\text { Specimens }\end{array}$ & $\begin{array}{l}\text { Pitting: } 1 \mathrm{E} 4 / \mathrm{m}^{2},<0.5 \mathrm{~mm}^{2},<0.4 \mathrm{~mm} \\
\text { Light Crevice Attack: } 0.07 \mathrm{~mm} \text { deep } \\
\end{array}$ \\
\hline
\end{tabular}

Solution 12

\begin{tabular}{||l|l||}
\hline Immersed Specimens & $\begin{array}{l}\text { Pitting: } 2.5 \mathrm{E} 3 / \mathrm{m}^{2},<0.5 \mathrm{~mm}^{2},<0.4 \mathrm{~mm} \\
\text { Light Crevice Attack: } 0.04 \mathrm{~mm} \text { deep }\end{array}$ \\
\hline $\begin{array}{l}\text { Air/Soln Interface } \\
\text { Specimens }\end{array}$ & $\begin{array}{l}\text { Pitting: } 2.5 \mathrm{E} 3 / \mathrm{m}^{2},<0.5 \mathrm{~mm}^{2},<0.4 \mathrm{~mm} \\
\text { Moderate Crevice Attack: } 0.07 \mathrm{~mm} \text { deep } \\
\text { Waterline attack: } 0.05 \mathrm{~mm} \text { deep }\end{array}$ \\
\hline
\end{tabular}

Solution 13

\begin{tabular}{|c|c|}
\hline Immersed Specimens & $\begin{array}{l}\text { Pitting: none } \\
\text { Crevice Attack: none }\end{array}$ \\
\hline $\begin{array}{l}\text { Air/Soln Interface } \\
\text { Specimens }\end{array}$ & $\begin{array}{l}\text { Pitting: } 2.5 \mathrm{E} 3 / \mathrm{m}^{2},<0.5 \mathrm{~mm}^{2},<0.4 \mathrm{~mm} \\
\text { Crevice Attack: none }\end{array}$ \\
\hline
\end{tabular}


WHC-SD-WM-TI-765, Rev 0

Solution 14

\begin{tabular}{||l|l||}
\hline Immersed Specimens & $\begin{array}{l}\text { Pitting: none } \\
\text { Crevice Attack: none }\end{array}$ \\
\hline $\begin{array}{l}\text { Air/Soln Interface } \\
\text { Specimens }\end{array}$ & $\begin{array}{l}\text { Pitting: } 1 \mathrm{E} 4 / \mathrm{m}^{2},<0.5 \mathrm{~mm}^{2},<0.4 \mathrm{~mm} \\
\text { Crevice Attack: none } \\
\text { Light waterline attack: } 0.08 \mathrm{~mm} \text { deep }\end{array}$ \\
\hline
\end{tabular}

Solution 15

\begin{tabular}{||l|l||}
\hline Immersed Specimens & $\begin{array}{l}\text { Pitting: none } \\
\text { Crevice Attack: none }\end{array}$ \\
\hline $\begin{array}{l}\text { Air/Soln Interface } \\
\text { Specimens }\end{array}$ & Pitting: $2.5 \mathrm{E} 3 / \mathrm{m}^{2}, 1.27 \mathrm{~mm}^{2},<0.4 \mathrm{~mm}$ \\
& Light Crevice Attack: $0.05 \mathrm{~mm}$ \\
& Light waterline attack: $0.02 \mathrm{~mm}$ deep \\
\hline
\end{tabular}

Solution 16

\begin{tabular}{||l|l||}
\hline Immersed Specimens & $\begin{array}{l}\text { Pitting: none } \\
\text { Light Crevice Attack: } 0.02 \mathrm{~mm} \text { deep }\end{array}$ \\
\hline $\begin{array}{l}\text { Air/Soln Interface } \\
\text { Specimens }\end{array}$ & $\begin{array}{l}\text { Pitting: } 1 \mathrm{E} 4 / \mathrm{m}^{2}, 0.81 \mathrm{~mm}^{2},<0.4 \mathrm{~mm} \\
\text { Very Light Crevice Attack: } 0.02 \mathrm{~mm} \text { deep } \\
\end{array}$ \\
\hline
\end{tabular}

F. 5 
WHC-SD-WM-TI-765, Rev 0

Solution 17

\begin{tabular}{||l|l|}
\hline Immersed Specimens & $\begin{array}{l}\text { Pitting: none } \\
\text { Crevice Attack: none }\end{array}$ \\
\hline $\begin{array}{l}\text { Air/Soln Interface } \\
\text { Specimens }\end{array}$ & $\begin{array}{l}\text { Pitting: } 5 E 4 / \mathrm{m}^{2}, 1.27 \mathrm{~mm}^{2},<0.4 \mathrm{~mm} \\
\text { Very Light Crevice Attack: } 0.07 \mathrm{~mm} \text { deep }\end{array}$ \\
\hline
\end{tabular}

Solution 18

\begin{tabular}{|c|c|}
\hline Immersed Specimens & $\begin{array}{l}\text { Pitting: none } \\
\text { Crevice Attack: none }\end{array}$ \\
\hline $\begin{array}{l}\text { Air/Soln Interface } \\
\text { Specimens }\end{array}$ & $\begin{array}{l}\text { Pitting: } 1 E 4 / \mathrm{m}^{2}, 0.81 \mathrm{~mm}^{2},<0.4 \mathrm{~mm} \\
\text { Light Crevice Attack: on one U-bend } 0.08 \\
\text { mm deep }\end{array}$ \\
\hline
\end{tabular}

Solution 19

\begin{tabular}{|c|c|}
\hline Immersed Specimens & $\begin{array}{l}\text { Pitting: } 2.5 \mathrm{E} 3 / \mathrm{m}^{2},<0.5 \mathrm{~mm}^{2},<0.4 \mathrm{~mm} \\
\text { Light Crevice Attack: on U-bend } 0.11 \mathrm{~mm} \\
\text { deep }\end{array}$ \\
\hline $\begin{array}{l}\text { Air/Soln Interface } \\
\text { Specimens }\end{array}$ & $\begin{array}{l}\text { Pitting: } 1 \mathrm{E} 4 / \mathrm{m}^{2},<0.5 \mathrm{~mm}^{2},<0.4 \mathrm{~mm} \\
\text { Light Crevice Attack: } 0.14 \mathrm{~mm} \text { deep } \\
\text { Waterline attack: } 0.02 \mathrm{~mm} \text { deep. }\end{array}$ \\
\hline
\end{tabular}

Solution 20

\begin{tabular}{||l|l||}
\hline Immersed Specimens & $\begin{array}{l}\text { Pitting: } 2.5 \mathrm{E} 3 / \mathrm{m}^{2},<0.5 \mathrm{~mm}^{2},<0.4 \mathrm{~mm} \\
\text { Crevice Attack: none }\end{array}$ \\
\hline $\begin{array}{l}\text { Air/Soln Interface } \\
\text { Specimens }\end{array}$ & $\begin{array}{l}\text { Pitting: } 1 \mathrm{E} 4 / \mathrm{m}^{2}, 0.81 \mathrm{~mm}^{2},<0.4 \mathrm{~mm} \\
\text { Light Crevice Attack: } 0.08 \mathrm{~mm} \text { deep } \\
\text { Waterline attack: } 0.03 \mathrm{~mm} \text { deep }\end{array}$ \\
\hline
\end{tabular}

F. 6 
Solution 21

\begin{tabular}{||l|l||}
\hline Immersed Specimens & $\begin{array}{l}\text { Pipting: none, grainy appearance to } \\
\text { surface } \\
\text { Crevice Attack: } 0.37 \mathrm{~mm} \text { deep }\end{array}$ \\
\hline $\begin{array}{l}\text { Air/Soln Interface } \\
\text { Specimens }\end{array}$ & $\begin{array}{l}\text { gross general attack, especially at and } \\
\text { just above waterline }\end{array}$ \\
\hline
\end{tabular}

Solution 22

\begin{tabular}{||l|l||}
\hline Immersed Specimens & $\begin{array}{r}\text { Pitting: pronounced pitting } \\
1 \mathrm{E} 5 / \mathrm{m}^{2},<0.5 \mathrm{~mm}^{2},<0.4 \mathrm{~mm}\end{array}$ \\
\hline $\begin{array}{l}\text { Air/Soln Interface } \\
\text { Specimens }\end{array}$ & $\begin{array}{l}\text { gross general attack, especially. at and } \\
\text { just above waterline }\end{array}$ \\
\hline
\end{tabular}

\section{Solution 23}

\begin{tabular}{||l|l||}
\hline Immersed Specimens & $\begin{array}{l}\text { Pitting: } 1 \mathrm{E} 4 / \mathrm{m}^{2},<0.5 \mathrm{~mm}^{2},<0.4 \mathrm{~mm} \\
\text { Light Crevice Attack: } 0.38 \mathrm{~mm} \text { deep }\end{array}$ \\
\hline $\begin{array}{l}\text { Air/Soln Interface } \\
\text { Specimens }\end{array}$ & $\begin{array}{l}\text { gross general attack, especially at and } \\
\text { just above waterline }\end{array}$ \\
\hline
\end{tabular}

Solution 24

\begin{tabular}{||l|l||}
\hline Immersed Specimens & $\begin{array}{r}\text { Pitting: slight pitting } \\
2.5 \mathrm{E} 3 / \mathrm{m}^{2},<0.5 \mathrm{~mm}^{2},<0.4 \mathrm{~mm}\end{array}$ \\
& $\begin{array}{r}\text { Very Light Crevice Attack: } 0.09 \mathrm{~mm} \text { deep } \\
\hline \begin{array}{l}\text { Air/Soln Interface } \\
\text { Specimens }\end{array}\end{array}$ \\
\hline
\end{tabular}




\begin{tabular}{|c|c|c|c|c|c|}
\hline \multicolumn{6}{|c|}{ DISTRIBUTION SHEET } \\
\hline \multirow{2}{*}{$\begin{array}{l}\text { To } \\
\text { Distribution }\end{array}$} & \multirow{2}{*}{\multicolumn{3}{|c|}{$\begin{array}{l}\text { From } \\
\text { Retrievä Engineering } 73530\end{array}$}} & \multicolumn{2}{|l|}{ Page 1 of 1} \\
\hline & & & & \multicolumn{2}{|c|}{ Date JuTy 31,1996} \\
\hline \multicolumn{4}{|l|}{ Project Title/Work Order } & \multicolumn{2}{|c|}{ EDT No. 605663} \\
\hline \multicolumn{4}{|c|}{$\begin{array}{l}\text { Pretreatment Applied Engineering, Corrosion Assessment for Tank } \\
\text { Materials: } 1995 \text { Final Report }\end{array}$} & \multicolumn{2}{|l|}{ ECN No. } \\
\hline Name & MSIN & $\begin{array}{l}\text { Text } \\
\text { With All } \\
\text { Attach. }\end{array}$ & Text Only & $\begin{array}{l}\text { Attach./ } \\
\text { Appendix } \\
\text { Only } \\
\end{array}$ & $\begin{array}{l}\text { EDT/ECN } \\
\text { Only }\end{array}$ \\
\hline $\begin{array}{l}\text { R. P. Anantatmula } \\
\text { N. G. Awadalla } \\
\text { W. B. Barton } \\
\text { L. D. Blackburn } \\
\text { K. O. Carouthers } \\
\text { M. J. Danielson (5) } \\
\text { R. A. Dodd } \\
\text { G. L. Edgemon } \\
\text { N. W. Kirch } \\
\text { A. L. Lund (5) } \\
\text { G. T. MacLean (10) } \\
\text { R. P. Marshal1 } \\
\text { J. L. Nelson } \\
\text { P. C. Ohl } \\
\text { D. E. Place } \\
\text { E. B. Schwenk } \\
\text { K. V. Scott } \\
\text { Central Files }\end{array}$ & $\begin{array}{l}\text { R1-30 } \\
H 6-35 \\
R 2-11 \\
R 1-56 \\
R 1-56 \\
P 8-15 \\
\text { S5-07 } \\
R 1-30 \\
R 2-11 \\
P 8-15 \\
H 5-61 \\
H 5-61 \\
R 1-30 \\
R 1-30 \\
H 5-27 \\
H 5-52 \\
H 5-52 \\
\text { A3-88 }\end{array}$ & $\begin{array}{l}\mathrm{x} \\
\mathrm{x} \\
\mathrm{x} \\
\mathrm{x} \\
\mathrm{x} \\
\mathrm{x} \\
\mathrm{x} \\
\mathrm{x} \\
\mathrm{x} \\
\mathrm{x} \\
\mathrm{x} \\
\mathrm{x} \\
\mathrm{x} \\
\mathrm{x} \\
\mathrm{x} \\
\mathrm{x} \\
\mathrm{x} \\
\mathrm{x}\end{array}$ & & & \\
\hline
\end{tabular}

